\title{
Antitrust and the Patent System: A Reexamination
}

\author{
HERBERT HOVENKAMP* \\ TABLE OF CONTENTS
}

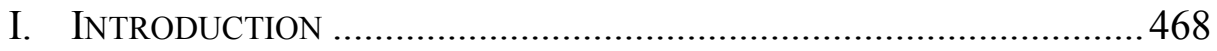

II. Antitrust AND PATENT LAW AS REGULATORS ............................ 475

A. "Beyond the Scope".........................................................476

B. Regulation and Three Areas of Patentee Conduct...............479

1. Pre-vs. Post-Issuance Practices .................................. 479

2. Authorized vs. Unauthorized Post-Issuance

Practices .................................................................... 481

C. Consumer Welfare and Intellectual Property Law ............. 482

D. Antitrust Capture: The Government as Buyer ..................... 487

III. Patent Regulation AND the ACtaVis DeCision ........................ 491

IV. PATENT AND ANTITRUST APPROACHES TO COMPETITION AND

INNOVATION: COMPARATIVE ADVANTAGE....................................496

A. Nonreciprocal Accommodation .........................................496

B. Uneven Empirical Research ..............................................499

C. Economics and Statutory Language .................................500

D. Innovation, Competition, and Market Diversity ..................503

E. Asymmetric Appellate Process............................................504

V. ECONOMIC ANALYSIS OF PATENT LAW PERFoRMANCE.................504

A. Innovation and Economic Growth ....................................505

B. Innovation and Market Structure ......................................506

C. Economic Effects of Patent Practices ..................................507

D. Patents, Economic Growth, and the Direction of Innovation ......................................................................... 508

E. The Economic Performance of Specific Patent

Doctrines ..................................................................... 510

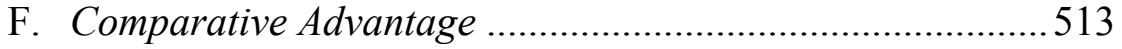

VI. RESTRAINTS ON INNOVATION ......................................................513

VII. USING PATENT AND ANTITRUST LAW TO ASSESS

INNOVATION-AFFECTING ANTICOMPETITIVE CONDUCT .............515

A. Principles for Resolving Antitrust/Patent Conflicts.............515

B. Product Restraints vs. Patent Restraints ........................... 517

C. Modes of Antitrust Inquiry ................................................518

D. Settlements ..................................................................... 521

\footnotetext{
* Ben V. \& Dorothy Willie Professor, University of Iowa College of Law.
} 
VIII. SPECIFIC PRACTICES IMPLiCATING ANTITRUST AND

PATENT LAW 523

A. Product Price Fixing and Horizontal Market Division ....... 524

B. Pooling, Cross-Licensing, and Standard Setting of Patented Technologies.

C. Grantbacks and Market Regimentation .............................536

D. Purely Vertical Practices ................................................538

E. Royalty "Extensions" ..........................................................54

F. Antitrust and Patent Enforcement......................................548

G. Walker Process: Objectively Unreasonable Infringement

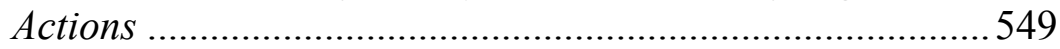

H. Refusal to License: Unilateral and Concerted.....................552

I. Overly Broad Remedial Demands: FRAND-Encumbered Patents .......................................................................... 554

J. Patent Acquisitions: Exclusive and Nonexclusive ...............555

K. Non-Practicing Patent Aggregators Generally .................. 558

IX. CONClusion: InNOVATION, COMPETITION, AND THE EQUitable POWERS OF COURTS...................................................................... 561

\section{INTRODUCTION}

Since the Sherman Act was passed, the federal antitrust laws have cycled through extreme positions on the relationship between competition policy and the patent system. Initially came a period of extreme deference, in which the Supreme Court rejected every antitrust challenge to a patent practice. The Court approved product price fixing in patent licenses, ${ }^{1}$ patent ties, ${ }^{2}$ and refusals to license externally acquired and unused patents. ${ }^{3}$ A single mention of patents in the 1914 Clayton Antitrust Act abruptly changed that. ${ }^{4}$ The Supreme Court began an aggressive campaign against patent "misuse" that placed severe limitations on patent practices. ${ }^{5}$ Under Thurman Arnold's

${ }^{1}$ See, e.g., Bement v. Nat'l Harrow Co., 186 U.S. 70, 91 (1902) (“"[T]he general rule is absolute freedom in the use or sale of rights under the patent laws of the United States. The very object of these laws is monopoly ....").

${ }^{2}$ See Henry v. A.B. Dick Co., 224 U.S. 1, 49 (1912).

${ }^{3}$ See Cont'l Paper Bag Co. v. E. Paper Bag Co., 210 U.S. 405, 429 (1908); see also Christina Bohannan \& Herbert HOVEnkamp, Creation Without Restraint: PROMOTING LIBERTY AND RIVALRY IN INNOVATION 295-98 (2012).

${ }^{4}$ See 15 U.S.C. $\$ 14$ (2012) (prohibiting anticompetitive tying or exclusive dealing in goods, "whether patented or unpatented"). For a historical perspective, see HERBERT Hovenkamp, The Opening of American Law: NeOclassical Legal Thought, 18701970, at 185-205 (2015).

${ }^{5}$ Motion Picture Patents Co. v. Universal Film Mfg. Co., 243 U.S. 502, 518 (1917) (overruling Henry v. A.B. Dick Co., 224 U.S. 1 (1912)). On the rise and fall of the patent "misuse" doctrine, see BOHANNAN \& HOVENKAMP, supra note 3, at 258-89. 
leadership of the Antitrust Division in the late 1930s and 1940s, these concerns migrated into antitrust law. ${ }^{6}$ At the same time, the Court invalidated an ever-increasing number of patents under a restrictive "inventive genius" test, prompting Justice Jackson to complain that "the only patent that is valid is one which this Court has not been able to get its hands on."7

The Supreme Court also developed the "leverage" theory, initially in patent misuse doctrine ${ }^{8}$ and later in antitrust law. ${ }^{9}$ Under that doctrine, a patent owner behaved anticompetitively when it adopted a practice that was thought to extend its power "beyond the scope" of the patent itself. ${ }^{10}$ For example, International Salt, Co. v. United States condemned a firm's tying of salt to its patented salt-injecting machine. ${ }^{11}$ The Court did not go so far as to say that such ties were condemned per se, without any showing of market power. It did what amounted to the same thing, however, by declaring that ownership of a patent created a presumption of sufficient power to make a patent tie unlawful. $^{12}$ That presumption stood for nearly sixty years until it was overruled in 2006. ${ }^{13}$ During its life, this presumption became the basis for many attacks on restrictions in patent licensees. ${ }^{14}$

The Supreme Court was hardly the sole instigator of hostility toward patents. It also came from the Antitrust Division of the Department of Justice. The Antitrust Division was largely responsible for spreading competition doctrine from patent "misuse," a set of judge-made rules that arose exclusively in private patent litigation, into government enforced antitrust policy. The high point of patent aggressiveness was around 1970, when the Antitrust Division articulated its "nine no nos" of patenting, virtually guaranteed to produce an antitrust challenge. This list included:

${ }^{6}$ See HovenKAMP, supra note 4, at 200-03.

${ }^{7}$ Jungersen v. Ostby \& Barton Co., 335 U.S. 560, 566, 572 (1949) (Jackson, J., dissenting) (applying the "inventive genius" standard and finding a lack of invention in combination of a well-known mold process and a well-known process of using centrifugal force to press melted wax into the mold; the process had been widely used with metals in the jewelry industry).

${ }^{8}$ See, e.g., Mercoid Corp. v. Minneapolis-Honeywell Regulator Co., 320 U.S. 680, 684 (1944) (refusing to enforce tie accomplished via a combination patent); Carbice Corp. of Am. v. Am. Patents Dev. Corp., 283 U.S. 27, 34-35 (1931) (refusing to enforce patent tie).

${ }^{9}$ United States v. Univis Lens Co., 316 U.S. 241, 254 (1942) (condemning RPM of lens blanks for bifocal glasses); Ethyl Gasoline Corp. v. United States, 309 U.S. 436, $457-$ 59 (1940) (condemning resale price maintenance of gasoline containing the appellant's "antiknock" compound). The extensive case law is discussed in 8 PHILLIP E. AREEDA \& HERBERT HOVENKAMP, ANTITRUST LAW 1 1621a (3d ed. 2010).

${ }^{10}$ See 8 AREEDA \& HovENKAMP, supra note 9, $\uparrow 1621 \mathrm{a}$.

${ }^{11}$ Int'1 Salt Co. v. United States, 332 U.S. 392, 396 (1947).

${ }^{12}$ Id. at 395-96, 403-04 (Frankfurter, J., dissenting in part).

13 Ill. Tool Works, Inc. v. Indep. Ink, Inc., 547 U.S. 28, 45-46 (2006).

${ }^{14}$ See 10 AREEDA \& HOVENKAMP, supra note 9, 19 1781-1782. 
1. Tying the purchase of unpatented materials as a condition of the license;

2. Requiring a licensee to assign back subsequent patents;

3. Restricting the resale right of a product's purchasers;

4. Restricting a licensee's ability to deal in products outside the scope of the patent;

5. Prohibiting a licensor from granting further licenses;

6. Requiring mandatory package licensing;

7. Requiring, as a condition of the license, royalties not reasonably related to the licensee's sales of products covered by the patent;

8. Restricting a licensee's use of a product made by a patented process; and

9. Setting minimum resale price provisions for licensed products. ${ }^{15}$

Most of the "nine no nos" described vertical practices, although "no no" number nine encompassed both horizontal price fixing and resale price maintenance. In a perverse turn, the decision in Bement v. National Harrow Co. and United States v. General Electric, Co. $(G E)$ twice rejected challenges to horizontal price fixing of patented products if the price fix clause was part of a patent license. ${ }^{16}$ Congress attempted repeatedly to overturn this "GE rule," but without success ${ }^{17}$ - a point that three dissenting Justices emphasized in the 1947 United States v. Line Materials Co. decision. ${ }^{18}$ There, a majority condemned a market wide price fixing agreement contained in patent crosslicenses. ${ }^{19}$ The antitrust enforcement agencies today largely ignore Bement and $G E,{ }^{20}$ even though they have never been overruled. In the 2013 FTC v. Actavis, Inc. decision, however, dicta in the majority opinion restricted their application to agreements between a "single patentee" and a "single

\footnotetext{
15 Bruce B. Wilson, Patent and Know-How License Agreements: Field of Use, Territorial, Price and Quantity Restrictions, in ANTITRUST PRIMER: PATENTS, Franchising, Treble Damage SuIts 11, 11-21 (Sara-Ann Sanders ed., 1970).

${ }^{16}$ See United States v. Gen. Elec. Co., 272 U.S. 476, 490 (1926); Bement v. Nat'1 Harrow Co., 186 U.S. 70, 93-95 (1902); see also infra text accompanying note 249.

${ }^{17}$ See Temp. NAT'L ECON. Comm. (TNEC), InVESTigation of CONCENTRATION of ECONOMIC POWER, S. Doc. No. 76-95, at 16-18 (1939); see also Grant W. Kelleher, PriceFixing Under Patent License Agreements, 3 MonT. L. REV. 5, 19-25 (1942). For harsh criticism of the Temporary National Economic Committee proposals on patents, see generally GEORge E. FolK, PATENTS AND IndUstrial Progress (1942).

${ }^{18}$ United States v. Line Material Co., 333 U.S. 287, 362-63 \& n.30 (1948) (Burton, J., dissenting).

${ }^{19} I d$. at 314 (majority opinion).

20 See, e.g., U.S. DeP'T OF Justice \& FED. Trade COMM’n, ANTITRUst Guidelines FOR THE LICENSING AND ACQUisition OF INTEllectual PROPERTY $§ 5.2$ (1995) [hereinafter IP ANTITRUST GUIDELINES], available at http://www.justice.gov/atr/public /guidelines/0558.htm, archived at http://perma.cc/QMX2-M4DA (citing GE only as a qualifier to its then-existing position that resale price maintenance is unlawful but never citing Bement).
} 
licensee."21 In 1913 and 1917, however, the Court twice applied antitrust law's per se rule to purely vertical price maintenance provisions in license agreements with dealers in patented products. ${ }^{22}$ The result was that for nearly a century purely vertical agreements on the pricing of patented goods were treated with greater hostility than agreements among competitors.

By the time the "nine no nos" were articulated, patent and antitrust doctrine had already come under blistering attack - particularly antitrust law's hostility toward patent ties, ${ }^{23}$ as well as its presumption that antitrust-imposed restrictions on patents would advance either competition or innovation. ${ }^{24}$ Today we are inclined to see patent tying arrangements as competitively benign in most cases. ${ }^{25}$ None of the "nine no nos" remains unlawful per se as a general matter. That includes number nine when applied to resale price maintenance, which was placed under the rule of reason in 2007 by the Supreme Court's decision in Leegin Creative Products, Inc. v. PSKS Inc. ${ }^{26}$ Market wide product price fixing among competitors is or should be an exception. ${ }^{27}$ Further, the presumption of market power is gone, and today patents are regarded in most cases as no more indicative of monopoly power than are land titles or other tangible property interests.

Both antitrust policy and patent policy are properly concerned with economic welfare, although the concerns are articulated more clearly in antitrust than in patent law. At the atmospheric level, antitrust focuses on the short run, including such things as immediate pricing and output, while patent law is concerned with long run issues relating to innovation. But upon inspection this dichotomy quickly breaks down. In fact, antitrust policy has always been concerned with performance over both the short and long runs and often considers effects on innovation.

${ }^{21}$ FTC v. Actavis, Inc., 133 S. Ct. 2223, 2232 (2013). The limitation is suggested in 12 Herbert HovenKamp, Antitrust Law 2041b (3d ed. 2012) (discussing Newburgh Moire Co. v. Superior Moire Co., 237 F.2d 283, 291-94 (3d Cir. 1956)).

${ }^{2}$ See Straus v. Victor Talking Mach. Co., 243 U.S. 490, 501 (1917); Bauer \& Cie v. O’Donnell, 229 U.S. 1, 17 (1913).

${ }^{2}$ See, e.g., Ward S. Bowman, Jr., Tying Arrangements and the Leverage Problem, 67 YALE L.J. 19, 20 (1957).

${ }^{24}$ See WARD S. Bowman, JR., PATENT AND Antitrust LaW: A Legal AND ECONOMIC APPRAISAL 239-56 (1973); William F. Baxter, Legal Restrictions on Exploitation of the Patent Monopoly: An Economic Analysis, 76 YALE L.J. 267, 312-13 (1966); see also John L. Murchison, Jr., Patent Acquisitions and the Antitrust Laws, 45 TEX. L. REV. 663, 663 (1967).

${ }^{25}$ See 9 AREEDA \& HovenKAMP, supra note 9, qा 1711-1717; Erik Hovenkamp \& Herbert Hovenkamp, Tying Arrangements, in OXFORD HANDBOOK OF INTERNATIONAL COMPETITION Policy (Daniel Sokol \& Roger D. Blair eds., 2015); Erik Hovenkamp \& Herbert Hovenkamp, Tying Arrangements and Antitrust Harm, 52 ARIZ. L. REV. 925, 926 (2010).

${ }^{26}$ Leegin Creative Leather Prods., Inc. v. PSKS, Inc., 551 U.S. 877, 907 (2007).

27 See infra notes 273-77 and accompanying text. 
Previous studies of antitrust law and the patent system have generally assumed that issued patents are valid, discrete, and generally of high quality in the sense that they further innovation. As a result, increasing the returns to patenting increases the incentive to do socially valuable innovation, whose gains must be traded off against the losses from patent exclusion. Ward Bowman addressed this tradeoff problem by presenting the patent as a kind of walled garden, protecting everything inside from antitrust scrutiny-provided that the activity remained inside the patent's lawful scope. He concluded:

[E]valuating whether certain patent licensing practices should be sanctioned will involve the proper scope of the legal monopoly. Is more being monopolized than what the patent grants, or is the practice merely maximizing the reward attributable to the competitive advantage afforded by a patent?28

In the mid-1980s, Louis Kaplow proposed a "ratio test" that assessed antitrust practices by balancing "patentee reward" against "monopoly loss."29 Kaplow himself recognized that the challenges in applying such a test are both "formidable" and "controversial." 30 Indeed, the relevant measurements required information about the optimal term of a patent. ${ }^{31}$ Not only is this term impossible to compute in litigation, it also varies considerably from industry to industry. ${ }^{32}$

${ }^{28}$ BOWMAN, JR., supra note 24, at 8-9 (emphasis added). In the process, Bowman dismissed Chicago economist Frank Knight's suggestion that the patent process undervalued those who did pure creative research and gave the reward to the one "who adds a detail or finishing touch that makes an idea practicable where the real work of pioneering and exploration has been done by others." FRANK H. KNIGHT, RISK, UnCERTAINTY AND PROFIT 372 (1921); see also THORSTEN KÄSEBERG, INTELlectuAL Property, ANTITRUST AND CUMULATIVE INNOVATION IN THE EU AND THE US 31-32 (2012); Amedeo Arena et al., Two Bodies of Law Separated by a Common Mission: Unilateral Conduct by Dominant Firms at the IP/Antitrust Intersection in the EU and the US, 9 EuR. COMPETITION J. 623, 623-24 (2013); Baxter, supra note 24, at 312; Michael A. Carrier, Unraveling the Patent-Antitrust Paradox, 150 U. PA. L. REV. 761, 762-65 (2002); Thomas K. Cheng, A Developmental Approach to the Patent-Antitrust Interface, 33 Nw. J. INT'L L. \& Bus. 1, 3-5 (2012); Thomas Cheng, Putting Innovation Incentives Back in the Patent-Antitrust Interface, 11 Nw. J. TeCH. \& INTELL. Prop. 385, 386-93 (2013); Gerald R. Gibbons, Price Fixing in Patent Licenses and the Antitrust Laws, 51 VA. L. REV. 273, 27378 (1965). See generally Robin Feldman, Patent and Antitrust: Differing Shades of Meaning, VA. J.L. \& TECH., Spring 2008, at 3 (arguing that much of the problem is semantic because the two systems use the same words to mean different things).

${ }^{29}$ Louis Kaplow, The Patent-Antitrust Intersection: A Reappraisal, 97 HARV. L. REV. 1813, 1831 (1984). Professor Kaplow explained: "In this ratio, 'patentee reward' and 'monopoly loss' refer, respectively, to the incremental reward and loss resulting from the practice in question. In general, the higher the ratio, the more desirable the practice." Id.

${ }^{30} I d$. at 1833 .

${ }^{31}$ Id. at 1831 .

32 See William M. Landes \& Richard A. Posner, The Economic Structure of INTELlectual PROPERTy LAW 294-300 (2003). On the question of different optimal periods in different industries, see Dan L. Burk \& Mark A. Lemley, Policy Levers in 
If a patent or patent practice does nothing to further innovation, however, then any amount of social loss from increased monopoly is harmful. In that case, there is no additional benefit from innovation down the road. Because only a subset of patents are worthless, this naturally invites the question whether considerations of patent social value are a reasonable element of competition policy.

Two premises drive the approach taken here. First, any resolution of patent/antitrust conflicts must be capable of judicial administration, although legislation can provide the relevant framework. This places the "patent social value" question out of bounds in most cases because it simply cannot be answered. Second, both antitrust and patent law are "regulatory" institutions, which respond to political as well as economic pressures. An approach to harmonization that assumes that patent law always "gets it right" will lead to significant errors, just as much as an approach that makes the same assumption about antitrust. Courts need to play the hands they are dealt, which are complex statutes that at least at the verbal level have surprisingly few inconsistencies. Further, judicial statutory construction is always subject to further congressional revision, as the history of both statutory regimes amply indicates. For example, in 1914, Congress responded with $\S 3$ of the Clayton Act to what it viewed as an irrational lack of judicial concern about patent ties. $^{33}$ It also responded to Supreme Court merger decisions in 1950 with expansions of the merger law. ${ }^{34}$ For its part, patent law was amended in 1952 in order to counter what Congress perceived as overly restrictive rules on patent issuance and excessively quick findings of misuse. It further limited misuse claims in $1988 .{ }^{35}$

In the current state of the law, antitrust is doing a better job of addressing the concerns within its domain than patent law is at addressing its concerns. Indeed, antitrust law is often a more effective promoter of innovation than our current patent system is. To be sure, at various points in their history both antitrust law and patent law have engaged in considerable overreaching. Beginning in the late 1970s, however, antitrust law went through a lengthy and still ongoing process of court-imposed discipline that has brought its rules more closely into alignment with its stated concern, which is increasing consumer welfare by promoting competition. Today, antitrust cases are far more difficult to win, the per se rule is less frequently used, and we have

Patent Law, 89 VA. L. REV. 1575, 1576-78 (2003); Richard Gilbert \& Carl Shapiro, Optimal Patent Length and Breadth, 21 RAND J. ECON. 106, 106-07 (1990); Robert P. Merges \& Richard R. Nelson, On the Complex Economics of Patent Scope, 90 CoLuM. L. REV. 839, 840 (1990). Important earlier literature includes WILliAM D. NORDHAUs, InVEntion, Growth, AND Welfare: A Theoretical Treatment of TECHNOLOGicAl Change (1969); F. M. Scherer, Nordhaus' Theory of Optimal Patent Life: A Geometric Reinterpretation, 62 AM. ECON. REV. 422 (1972).

33 See 15 U.S.C. $\$ 14$ (2012).

3415 U.S.C. $\$ 18$ (2012).

3535 U.S.C. $\$ 271(d)(4)-(5)(2012)$. 
considerably heightened the requirements of allegation and economic proof. ${ }^{36}$ By contrast, patent law has continued on an expansion course that is only now showing some signs of abating. Patent law still awaits the consumer welfare revolution that to a large extent has already occurred in antitrust doctrine. Writing in the mid-sixties, Ward S. Bowman and Robert H. Bork warned of a "crisis in antitrust," presaging the significant reform that was to follow. ${ }^{37}$ Today we are facing a similar crisis in patent law.

This Article first examines antitrust and patent law as regulatory institutions with legislative authority to manage their given areas, but subject to limitations that all regulatory institutions face-namely, high cost, imperfect information, and special interest capture. One failed approach to this regulatory enterprise was the view that the patentee acts improperly when it engages in activity "beyond the scope" of the patent. The flip side is that activity that is not "beyond the scope" is permissible. ${ }^{38}$ A more sensible way to view the interaction between the patent and antitrust regulatory systems is to divide patent activity into two parts: pre-issuance and post-issuance conduct. Secondly, one must look for explicit statutory authorization of the conduct in question. Post-issuance conduct that is not statutorily authorized is generally amenable to antitrust scrutiny. ${ }^{39} \mathrm{Next}$, we examine the antitrust and patent systems as regulatory institutions, finding that today the presence of special interest capture is far stronger in the patent system than the antitrust system, although that may not always have been the case. ${ }^{40}$

After that, we turn to the very different ways that antitrust and the patent system approach economic policy and innovation. The antitrust system is empirical, market based, and acutely sensitive to the differences that exist among markets. In sharp contrast, the patent system is dominated by a much more myopic set of queries concerned with the boundaries of individual property rights and largely indifferent to market performance and diversity. If one thinks of the antitrust system and the patent system as tools for promoting economic growth and consumer welfare, antitrust has distinct institutional advantages. ${ }^{41}$

36 See BoHANNAN \& HovenKAMP, supra note 3, at 33-59; infra notes 291-94 and accompanying text. The specific antitrust doctrines that gave effect to these changes are discussed in 2 AREEDA \& HOVENKAMP, supra note 9, ๆף 306-309 (discussing jury trial, complaint and summary judgment, and expert testimony); 2A AREEDA \& HOVENKAMP, supra note 9, $9 \uparrow$ 335-338 (discussing plaintiff standing, causation, and antitrust injury).

${ }^{37}$ Robert H. Bork \& Ward S. Bowman, Jr., The Crisis in Antitrust, ForTunE, Dec. 1963, at 138, reprinted in 65 COLUM. L. REV. 363, 363-66 (1965).

38 See Herbert Hovenkamp, The Rule of Reason and the Scope of the Patent, 52 SAN DIEGO L. REV. (forthcoming 2015) (manuscript at 1); see also infra notes 45-66 and accompanying text.

${ }^{39}$ See infra notes 67-82 and accompanying text.

40 See infra notes 83-116 and accompanying text.

41 See infra notes 135-63 and accompanying text. 
Finally, we develop a set of rules for evaluating specific disputes that implicate both antitrust and the patent system, focusing mainly on the difference between pre-issuance patent conduct, which is intensely regulated, and post-issuance conduct, as well as the differences between practices that are expressly authorized by the Patent Act and those that are not. Given the level of producer capture exhibited by the Patent Act, the search for express authorization is particularly important. A regulatory statute must be followed, even when it bargains away the public interest, but silence and ambiguity should be construed against the interests in control of the legislative process. These principles are applied to a number of practices, including price fixing in patent licenses, vertical practices, pay-for-delay settlements and other naked market division agreements, and improper patent enforcement actions. ${ }^{42}$

\section{ANTITRUST AND PATENT LAW AS REgUlators}

Both the antitrust and patent systems are regulatory institutions, calling for government intervention in market trading. Antitrust law's principal purpose is to correct market failures brought about by lack of competition or to discipline activities that seek to limit it. The patent system is intended to correct market failures that result when inventors cannot effectively appropriate the returns to their inventions.

Stating the concerns in this way exaggerates their separateness, however. The market failures that result from harm to competition frequently include loss of inventiveness or technical progress, and the patent system ideally accomplishes its goals by metering a tradeoff between exclusion and access. The latter requires competitiveness and the free mobility of assets. The result is a complex set of rules that reflect the relationship between these two systems, with one frequently required to accommodate the other. ${ }^{43}$

Nonetheless, a "tradeoff" is necessary only if there is something to trade off. For much of our history the courts have applied aggressive antitrust rules to patent practices when the antitrust rules themselves did nothing to further competition. For example, we do not need to "trade off" the competitive harm from patent tying arrangements with patent law in the vast majority of cases. The tie does no competitive harm to begin with. By the same token, however, there is nothing to trade off when the patent rule in question causes competitive harm but does nothing to further innovation. In this sense, the "crisis" of patent law overreaching today resembles the antitrust crisis of the 1960s and 1970s. ${ }^{44}$ For example, in the Trebro Manufacturing, Inc. v. Firefly

42 See infra notes 164-97 and accompanying text.

43 These rules are expressed in multi-volume treatises such as 1 HERBERT HovenKAMP ET AL., IP AND ANTITRUST: AN ANALYSIS OF ANTITRUST PRINCIPLES APPLIED TO INTELLECTUAL PRoperty LAW (2d ed. 2010 \& Supp. 2014).

${ }^{44}$ See Robert H. Bork, The Antitrust Paradox: A Policy at War with Itself (1978); Bork \& Bowman, Jr., supra note 37, at 363-64; see also RICHARD A. POSNER, 
Equipment, LLC decision, discussed below, the Court of Appeals for the Federal Circuit traded off a considerable loss of market competitiveness for a remedy that did absolutely nothing to further innovation. ${ }^{45}$

The most important development in patent/antitrust law in the last three decades is that antitrust has become narrower and much more rigorous about its mission to protect competition. ${ }^{46}$ At the same time, however, patent granting and interpretation have increasingly reflected producer capture and overbreadth. In addition, antitrust policy has become increasingly empirical, assessing practices by modeling impact on price, output, or other indicia of consumer welfare. In sharp contrast, patent law as applied in the courts has very little empirical economic content.

\section{A. "Beyond the Scope"}

One of the more unhelpful patent/competition rules is that a patent practice should be evaluated by querying whether it reaches "beyond the scope" of the patent grant. The formulation perpetuates the idea of the patent as a walled garden whose insides are largely free of scrutiny, while everything outside is challengeable. As noted above, Ward Bowman advocated "beyond the scope" as a way of demarcating the line between patents and antitrust. ${ }^{47}$

The "beyond the scope" formulation actually originated before the antitrust laws were passed, in nineteenth century cases involving patent term extensions applied retroactively to goods that had already been purchased. ${ }^{48} \mathrm{It}$ was later used to justify the judge-made first sale doctrine against patentees who attempted to enforce patents rights in goods that they had already sold. ${ }^{49}$ For example, in Adams v. Burke, Justice Bradley described such post-sale restraints as attempts to assert rights that are "no longer within the limits of the monopoly." 50 After that, the formulation was used to refer to unreasonably broad construction of patent claims. ${ }^{51}$ In the twentieth century it was extended

ANTITRUST LAW: AN ECONOMIC APPROACH 31 (1976) (analyzing the "crisis" in a less rhetorical but equally critical way).

45 Trebro Mfg., Inc. v. Firefly Equip., LLC, 748 F.3d 1159, 1172 (Fed. Cir. 2014); see infra note 140 and accompanying text.

${ }^{46}$ See generally BORK, supra note 44; Herbert HovenKAMP, THE ANTITRUST ENTERPRISE: PRINCIPLE AND EXECUTION (2005).

47 See supra note 28 and accompanying text.

48 The first use of the concept was in Bloomer v. McQuewan, 55 U.S. (14 How.) 539, 549 (1852). See also Herbert Hovenkamp, Inventing the Classical Constitution 57 (Univ. Iowa Legal Studies, Working Paper No. 14-20, 2015), available at papers.ssrn.com/sol3 /papers.cfm?abstract_id=2486612, archived at http://perma.cc/S83V-QN27.

${ }^{49}$ See Herbert Hovenkamp, Post-Sale Restraints and Competitive Harm: The First Sale Doctrine in Perspective, 66 N.Y.U. AnN. SuRV. AM. L. 487, 487 (2011).

50 Adams v. Burke, 84 U.S. (17 Wall.) 453, 460 (1873).

${ }^{51}$ See, e.g., Coupe v. Royer, 155 U.S. 565, 576 (1895) (noting that overly broad interpretation served to "enlarge a patent beyond the scope of its claim, as allowed by the Patent Office"). 
to cover patent practices such as cross-licenses and ties. For example in condemning a product price fix in a licensing agreement in 1948, Justice Burton noted that if the terms of the license "reach beyond the scope of the statutory patent rights, then they must be tested by the terms of the Sherman Act." 52

The "beyond the scope" idea was essentially that a patent is a type of monopoly defined by boundaries, identified by its written description and claims. Certain actions were thought to enlarge this monopoly by extending its power outside, or "beyond the scope," of the patent grant. As Justice Douglas stated in the 1944 Mercoid Corp. v. Mid-Continent Investment Co. decision, the law:

denies to the patentee after issuance the power to use it in such a way as to acquire a monopoly which is not plainly within the terms of the grant. The necessities or convenience of the patentee do not justify any use of the monopoly of the patent to create another monopoly. The fact that the patentee has the power to refuse a license does not enable him to enlarge the monopoly of the patent by the expedient of attaching conditions to its use. ${ }^{53}$

The "beyond the scope" formulation has led courts to two different ideas, both of which lack either conceptual or empirical support. One is that any patent practice that reaches "beyond the scope" of the patent is competitively harmful. The other is that a patent practice that does not reach "beyond the scope" of the patent is benign or untouchable.

As a matter of competition policy, the "beyond the scope" formulation makes little sense. Antitrust is concerned with practices that are not authorized by other statutory provisions and realistically reduce output and raise price. Some contractual restrictions do this, while most do not, but the "beyond the scope" analysis adds nothing to that determination. This is why the dissenters in FTC v. Actavis, Inc. were wrong to conclude that a naked market division agreement should be regarded as lawful because it did not stretch "beyond the scope" of the patent. ${ }^{54}$ Naked market division, the practice at issue in Actavis, is not authorized by the Patent Act, whether or not the agreement goes beyond the scope of the patent.

The Actavis decision suggests that the Supreme Court may be finished with the walled garden approach reflected in the "scope of the patent" test. ${ }^{55}$ To be sure, that approach made some sense in the early 1970s when Bowman

52 United States v. Line Material Co., 333 U.S. 287, 353 (1948) (Burton, J., dissenting); see also Mercoid Corp. v. Mid-Continent Inv. Co., 320 U.S. 661, 662 (1944) (involving patent tie affected through combination patent); United States v. Gen. Elec. Co., 80 F. Supp. 989, 1005 (S.D.N.Y. 1948).

${ }^{53}$ Mercoid, 320 U.S. at 665-66.

${ }^{54}$ FTC v. Actavis, Inc., 133 S. Ct. 2223, 2241 (2013) (Roberts, C.J., dissenting). Both Justice Breyer's opinion for the Court and the Chief Justice's dissent also used the phrase "beyond the limits of the patent monopoly." Id. at 2231 (majority opinion); id. at 2240 (Roberts, C.J., dissenting) (emphasis omitted).

55 See supra note 28 and accompanying text. 
was writing. At that time, antitrust policy was unreasonably hostile toward a wide variety of conduct, particularly vertical practices that we regard today as economically harmless. The walled garden protected the patent from significant antitrust overreaching. But today the tables have turned, and the overreaching is going in the other direction.

To be sure, as a matter of patent policy, "beyond the scope" inquiries are meaningful to the extent that patents grant what they grant and no more. As a result, nineteenth century courts rightly complained that overly broad claim constructions were judicial attempts to extend the patent beyond its granted scope ${ }^{56}$ More recently, broad use of the doctrine of equivalents produced similar complaints. ${ }^{57}$ The same thing is true of attempts to enforce patents beyond their expiration date, ${ }^{58}$ or to enforce them against defendants who are clearly not infringers. ${ }^{59}$ These are all fundamentally questions of patent law, and the "scope" question concerns the location of a patent's boundaries. The antitrust question necessarily reaches more broadly to concerns about impact on markets and the resulting effects on price, output, or innovation. As in the law of real property, the owner's "scope" defines what he or she may do as a matter of property law, such as evicting trespassers, but it says virtually nothing about anticompetitive uses that are reachable under antitrust law.

The "beyond the scope" formulation is a relic of a bygone approach to antitrust and regulation, in force at Bowman's time, which regarded regulation as "ousting" antitrust from the regulated market altogether. ${ }^{60}$ Once an area was deemed to be pervasively regulated, antitrust law had no place. As a result, the scope of antitrust immunity was a set of boundaries largely defined by the scope of a regulator's jurisdiction. Practices within that jurisdiction required oversight by the particular regulatory agency in charge, not by antitrust law. As Chief Justice Roberts put it in his Actavis dissent, "the scope of the patent - i.e., the rights conferred by the patent - forms the zone within which the patent holder may operate without facing antitrust liability." 61

This approach also grew out of an era that was much more optimistic about regulation than we are today, regarding it as a complete substitute for competition law with respect to matters within its domain. ${ }^{62}$ After decades of

${ }^{56}$ See Coupe, 155 U.S. at 576.

${ }^{57}$ See London v. Carson Pirie Scott \& Co., 946 F.2d 1534, 1538 (Fed. Cir. 1991) (stating that patent law doctrine of equivalents should not be construed as "regularly available to extend protection beyond the scope of the [patent] claims"); see also Johnson \& Johnston Assocs., Inc. v. R.E. Serv. Co., 285 F.3d 1046, 1055 (Fed. Cir. 2002).

${ }^{58}$ See Int'1 Tech. Consultants, Inc. v. Pilkington PLC, 137 F.3d 1382, 1393 (9th Cir. 1998).

${ }^{59}$ Eon-Net LP v. Flagstar Bancorp, 653 F.3d 1314, 1327 (Fed. Cir. 2011).

${ }^{60} \mathrm{See}$ Hughes Tool Co. v. Trans World Airlines, Inc., 409 U.S. 363, 389 (1973); Pan Am. World Airways, Inc. v. United States, 371 U.S. 296, 309-10 (1963); see also 1A AREEDA \& HOVENKAMP, supra note 9, ๆף 244b-244c.

${ }^{61}$ FTC v. Actavis, Inc., 133 S. Ct. 2223, 2238 (2013) (Roberts, C.J., dissenting).

62 See United States v. Phila. Nat'l Bank, 374 U.S. 321, 351 (1963) (discussing the holding of Pan Am., stating "that because the Civil Aeronautics Board had been given 
exposure to ideas about regulatory capture, incompleteness, conflicts, and other imperfections in regulatory regimes, attitudes have changed. Today we look at competition issues in regulated markets much more critically and focus more narrowly on the issue at hand. Antitrust policy yields if the regulatory provision or the courts interpreting it have jurisdiction over a particular practice and have controlled it as "effective steward[s] of the antitrust function." 63 Private conduct that is not expressly authorized by the statute enjoys no such status, particularly if the agency itself has not asserted control. ${ }^{64}$ In particular, regulatory defenses to antitrust claims should not be taken seriously when activity that is not authorized by statute is also "neither compelled nor approved by any governmental, regulatory body." 65 As the Supreme Court observed:

To be sure, where Congress did intend to repeal the antitrust laws, that intent governs, ... but this intent must be clear. Even when an industry is regulated substantially, this does not necessarily evidence an intent to repeal the antitrust laws with respect to every action taken within the industry. . . . Intent to repeal the antitrust laws is much clearer when a regulatory agency has been empowered to authorize or require the type of conduct under antitrust challenge. ${ }^{66}$

\section{B. Regulation and Three Areas of Patentee Conduct}

As an alternative to "beyond the scope," it is more useful to divide patentee conduct raising competition issues into three areas. The first is preissuance conduct involving the patent application and prosecution process, all of which is under the intensive supervision of the United States Patent and Trademark Office (USPTO) and its examiners, as well as the Court of Appeals for the Federal Circuit, and occasionally the Supreme Court. The second area concerns post-issuance conduct that is expressly authorized by the Patent Act, or occasionally, some other federal statutory provision. The third concerns post-issuance conduct that is not authorized by the statute.

\section{Pre-vs. Post-Issuance Practices}

The regulatory approach just described suggests powerful differences between patentee activity that occurs prior to patent issuance and that which

broad powers to enforce the competitive standard clearly delineated by the Civil Aeronautics Act, and to immunize a variety of transactions from the operation of the antitrust laws, the Sherman Act could not be applied to facts composing the precise ingredients of a case subject to the Board's broad regulatory and remedial powers").

${ }^{63}$ Verizon Commc'ns, Inc. v. Law Offices of Curtis V. Trinko, LLP, 540 U.S. 398, 413 (2004).

64 See 1A AREEDA \& HovenKAMP, supra note 9, ๆๆ 241, 243.

65 Nat'l Gerimedical Hosp. v. Blue Cross, 452 U.S. 378, 389 (1981).

${ }^{66} I d$. 
occurs after. Prior to issuance, the patent process is subject to intensive public agency scrutiny - far more, in fact, than is the conduct of many private firms under regulatory oversight. Patent applications must be filed with the USPTO. During the patent prosecution process, the applicant may rewrite some portions of the proposed patent, add or subtract claims, or even divide complex patents into two or more. At every stage, however, the decision whether or not a patent will issue - and its final text - is given to a government official. To be sure, the USPTO might issue too many patents or permit overly broad or vague claims, but these are not matters of antitrust concern. It is not antitrust law's purpose to police shortcomings in other regulatory agencies.

One possible exception is the Walker Process doctrine, discussed below, which can make it unlawful under the antitrust laws to enforce a patent obtained by fraud or inequitable conduct during the patent prosecution process, provided that the enforcement action threatens to create or maintain a monopoly. ${ }^{67}$ The doctrine is applied very sparingly, however, and with good reason. Patent law contains its own provisions that discipline improper conduct in the patent prosecution process, ranging from invalidation to the award of attorney's fees against patent infringement plaintiffs who abuse the process. ${ }^{68}$ Once again, the Federal Circuit may be too generous to patentees in this area. ${ }^{69}$ But that is not an antitrust problem.

In any event, Walker Process is not about pre-issuance conduct as such. It is concerned with infringement actions, which occur post-issuance. The relevant question is whether the infringement plaintiff sued with an objectively reasonable expectation of success, measured from the time that the infringement lawsuit was filed. ${ }^{70}$

Once a patent goes "out the door," so to speak, the amount of USPTO supervision changes dramatically, from very high to almost non-existent. The USPTO does have jurisdiction for re-examination, payment of maintenance fees, and a few housekeeping matters. By and large, however, an issued patent is completely in the control of its owner, subject to express limitations in the Patent Act. It is treated for antitrust purposes much as any business asset. No one supervises licensing and transfer practices, although there is a passive recordation requirement for assignments, protecting bona fide purchasers without notice. ${ }^{71}$ Licensing decisions, patent ties, exclusive dealing

${ }^{67}$ Walker Process Equip., Inc. v. Food Mach. \& Chem. Corp., 382 U.S. 172, 177 (1965); Nobelpharma AB v. Implant Innovations, Inc., 141 F.3d 1059, 1073 (Fed. Cir. 1998); see also 3 AREEDA \& HOVENKAMP, supra note 9, $₫ 706$.

68 See 3 AREEDA \& HOVENKAMP, supra note 9, ๆ705a. But see infra text accompanying notes 411-13 (suggesting that these tools are inadequate).

${ }^{69}$ See Octane Fitness, LLC v. ICON Health \& Fitness, Inc., 134 S. Ct. 1749, 1758 (2014) (rejecting very strict Federal Circuit standard for assessing allegedly improper enforcement conduct by a patent infringement plaintiff).

703 AREEDA \& HOVENKAMP, supra note 9, $19706 \mathrm{a}, 706 \mathrm{~b}$.

7135 U.S.C. $§ 261$ (2012) (making assignments void against subsequent bona fide purchasers (BFPs) without notice unless recorded within three months of transfer). 
agreements, mergers, pricing of both licenses and products, and exclusionary practices are all within the patent owner's control with no regulatory oversight.

\section{Authorized vs. Unauthorized Post-Issuance Practices}

Explicit statutory authorizations are immune from antitrust scrutiny even if there is not regulatory supervision. Many provisions of this kind do not require much supervision in any event. For example, once federal law requires new cars to be equipped with seat belts, it cannot be an unlawful antitrust tying arrangement for a car manufacturer to refuse to sell an automobile without them. ${ }^{72}$ In such cases the specific authorization in a federal statute controls the more general terms of the antitrust laws.

Just as any regulatory provision, the Patent Act removes certain activities from antitrust scrutiny. For example, once the Patent Act authorizes a patent for a given term, exclusion by patent enforcement during that term cannot be unlawful under the antitrust laws. ${ }^{73}$ The same thing is true of other practices that the statute authorizes, including exclusive and nonexclusive production licenses, ${ }^{74}$ ties in the absence of market power, ${ }^{75}$ simple refusals to license, ${ }^{76}$ and patent assignments. ${ }^{77}$

On the other hand, the Patent Act does not authorize product price fixing, market divisions unrelated to production licenses, predatory pricing in patented goods, anticompetitive acquisitions, ${ }^{78}$ resale price maintenance of patented goods, ties in the presence of market power, exclusive dealing, or infringement suits based on patents that the owner knows or should know are invalid or unenforceable under the circumstances. The Patent Act expressly permits unilateral refusals to license, but does not say anything about concerted refusals to licenses - although the Federal Circuit suggested to the contrary in its Princo Corp. v. International Trade Commission decision. ${ }^{79}$ Nor does it have anything to say about practices that have been compared to tying, including package licensing, royalties attached to unpatented goods produced with a patented process, or agreements requiring the making of royalty-like payments that extend past the patent's term. ${ }^{80}$ It nowhere

7249 U.S.C. § 30127 (2012); see also 1A AREEDA \& HovENKAMP, supra note 9, 9ा $242 \mathrm{a}, 243 \mathrm{~b}(2)$.

7335 U.S.C. $\$ 271(d)(3)(2012)$.

7435 U.S.C. $\S \S 261,271(\mathrm{~d})(2)(2012)$.

${ }^{75} \mathrm{Id}$. $\$ 271(\mathrm{~d})(5)$.

${ }^{76}$ Id. § 271(d)(4).

${ }^{77} I d . \S 261$.

${ }^{78}$ See 5 AREEDA \& HOVENKAMP, supra note 9, $91202 \mathrm{f}$.

${ }^{79}$ Princo Corp. v. Int'1 Trade Comm'n, 616 F.3d 1318, 1330 (Fed. Cir. 2010) (en banc); see also Christina Bohannan \& Herbert Hovenkamp, Concerted Refusals to License Intellectual Property Rights, 1 HARV. Bus. L. REV. ONLINE 21, 21-23 (2011).

${ }^{80}$ See infra notes 393-400 and accompanying text. 
authorizes payments to others to cease production in ways that would infringe the patent, assuming that it is valid. ${ }^{81}$

Importantly, most of the practices in this list are not antitrust violations either. Indeed, far fewer practices are regarded as antitrust violations today than were so regarded in 1970, when the Justice Department's list of "nine no nos" was issued. ${ }^{82}$ The significance of the list is that these are practices that can be made subject to antitrust scrutiny and condemned if a suitable threat to competition is established under ordinary antitrust rules.

\section{Consumer Welfare and Intellectual Property Law}

The change in attitudes about the relationship between antitrust and regulation was heavily driven by concerns about regulatory capture, particularly by producer interests. As noted previously, the idea that regulation should "oust" antitrust was driven by an optimistic public interest attitude toward regulation that subsequently came under intense scrutiny. ${ }^{83}$ An age that is more skeptical about regulation naturally looks with beadier eyes. Rather than seeing regulatory legislation as serving the public interest, we are more likely to view it as a response to the political pressures of organized interest groups, or as a set of "deals" made with the legislature. Interest groups that are better organized, more homogenous, and have larger individual stakes invest much more than large, diffuse groups whose individual stakes are small. In this process, consumers often come out as losers because their interests are diverse and individually quite small, even though there are millions of them. ${ }^{84}$

The most effective ways to limit the effects of capture are, first, to confine regulatory intervention to situations where it is absolutely necessary. This principle applies to both antitrust law and patent issuance and enforcement. Second, government decision makers need to be more transparent when they

\footnotetext{
${ }^{81}$ See FTC v. Actavis, Inc., 133 S. Ct. 2223, 2227 (2013); see also infra notes 393400 and accompanying text.

82 See supra note 15 and accompanying text.

83 See HoVENKAMP, supra note 4, at 307-14.

${ }^{84}$ See generally DANIEL A. FARBER \& PhILIP P. FRICKEY, LAW AND PUBLIC CHOICE: A Critical Introduction (1991); Dennis C. Mueller, Public Choice III (2003); RICHARD TUCK, FREE RIDING (2008). The economic arguments for capture theory were developed in Mancur Olson's classic work. See Mancur Olson, JR., ThE Logic OF Collective Action: Public Goods And the Theory of Groups (1965); see also Sam Peltzman, Toward a More General Theory of Regulation, 19 J.L. \& ECON. 211, 213 (1976); Richard A. Posner, Theories of Economic Regulation, 5 BeLl J. ECON. \& MGMT. SCI. 335, 335 (1974); George J. Stigler, The Theory of Economic Regulation, 2 BELL J. ECON. \& Mgmt. ScI. 3, 3 (1971). See generally Rachel E. Barkow, Insulating Agencies: Avoiding Capture Through Institutional Design, 89 TEX. L. REV. 15 (2010). For a historical perspective, see HovenKAMP, supra note 4, at 308-14; Richard A. Posner, The Concept of Regulatory Capture: A Short, Inglorious History, in PREVENTING REgUlatory CAPTURE: SPECIAL INTEREST INFLUENCE AND How TO LIMIT IT 49, 49-56 (Daniel Carpenter \& David A. Moss eds., 2013).
} 
remove practices from competitive constraints. Explicit legislation that is otherwise valid cannot be overturned simply because it is a product of capture, but the courts need not go beyond the statutory text and give private firms greater anticompetitive power than they were able to bargain for in the legislative process. ${ }^{85}$

The intellectual property laws, but particularly copyright and patent, are among the most captured regimes in the American legal system today. ${ }^{86}$ By and large, Congress has listened to producers while paying little attention to the voices of consumers. One consequence of this is that patent law has not developed any equivalent to the "consumer welfare" prescription that has become so central to antitrust analysis. Even the dissenting Justices in the Actavis decision recognized the centrality of consumer welfare as an antitrust goal. ${ }^{87}$

The structural problems of capture in the patent system go much further, however. Patent prosecution remains a largely ex parte process in which patent examiners and other USPTO officials listen to patent applicants first and foremost. While there is some limited room for opposition, most of it occurs from other affected producers. ${ }^{88}$ One consequence of ineffectual opposition is that fields become very crowded with patents whose technological contributions are minimal or nonexistent. Nevertheless, the cost of challenging or avoiding them is very high. As a result, they can deter competitive entry and innovation even if they do little to promote long run technical progress. ${ }^{89} \mathrm{Just}$

85 See Frank H. Easterbrook, The Supreme Court, 1983 Term-Foreword: The Court and the Economic System, 98 HARV. L. REV. 4, 4-5 (1984); see also Frank H. Easterbrook, Statutes' Domains, 50 U. CHI. L. REV. 533, 534 (1983).

${ }^{86}$ See James Bessen \& Michael J. Meurer, Patent Failure: How Judges, Bureaucrats, AND LAWYERS PUT InNOVATORS AT Risk 1-28 (2008); BOHANNAN \& HovenKamp, supra note 3, at 60-160; DAN L. BURK \& MARK A. LEMLEY, The PATENT CRISIS AND How THE CourTs CAN SOlve IT 3-6 (2009); see also Stuart Minor Benjamin \& Arti K. Rai, Fixing Innovation Policy: A Structural Perspective, 77 GEO. WASH. L. REV. 1, 17-26 (2008) (discussing special interest capture of the Federal Circuit); Christina Bohannan, Reclaiming Copyright, 23 CARDOZO ARTS \& ENT. L.J. 567, 590-603 (2006); Robert P. Merges, One Hundred Years of Solicitude: Intellectual Property Law, 19002000, 88 CALIF. L. REV. 2187, 2236 (2000); Robert P. Merges, Intellectual Property Rights and the New Institutional Economics, 53 VAND. L. REV. 1857, 1875 (2000); Andrew P. Morriss \& Craig Allen Nard, Institutional Choice \& Interest Groups in the Development of American Patent Law: 1790-1865, 19 SuP. CT. ECON. REV. 143, 144-49 (2011); Liza Vertinsky, Comparing Alternative Institutional Paths to Patent Reform, 61 ALA. L. REV. 501, 526 (2010).

${ }^{87}$ FTC v. Actavis, Inc., 133 S. Ct. 2223, 2238 (2013) (Roberts, C.J., dissenting) ("The point of antitrust law is to encourage competitive markets to promote consumer welfare.").

${ }^{88}$ See Michael A. Carrier, Post-Grant Opposition: A Proposal and a Comparison to the America Invents Act, 45 U.C. DAVIS L. REV. 103, 105-06 (2011); see also Bronwyn H. Hall et al., Prospects for Improving U.S. Patent Quality via Postgrant Opposition, in 4 InNOVATION Policy \& THE ECONOMY 4, 115-17 (Adam B. Jaffe et al. eds., 2004).

${ }^{89}$ See Josh Lerner, Patenting in the Shadow of Competitors, 38 J.L. \& ECON. 463, 463-66 (1995). 
as the availability of patenting may affect the course of invention, ${ }^{90}$ so too the existence of heavily patented environments may serve to direct innovation away from these environments, at least on the part of new firms. In environments heavy in patent infringement suits filed by patent aggregators, incumbent firms often slow down or even stop innovating activity. ${ }^{91}$ In such cases there is no innovation-competition "tradeoff" because there is no innovation to trade off.

The history of interest group theory and intellectual property policy has been somewhat under researched. Public choice writers attacked government regulatory policy concerning the railroads, food and drugs, the environment, corporate securities and banking, or other areas with great enthusiasm. By contrast, intellectual property regulation traditionally enjoyed a privileged position-as if it were somehow exempt from the same processes of special interest capture that are at work in other regulatory areas. That is starting to change. ${ }^{92}$

90 See infra notes 191-94 and accompanying text.

91 See, e.g., Lauren Cohen et al., Patent Trolls: Evidence from Targeted Firms 6-7 (Harvard Bus. Sch. Fin., Working Paper No. 15-002, 2014), available at http://papers.ssrn.com/sol3/papers.cfm?abstract_id=2464303, archived at http://perma.cc /2U9R-7ZC5; Catherine Tucker, Patent Trolls and Technology Diffusion (TILEC, Discussion Paper No. 2012-030, 2013), available at http://papers.ssrn.com/sol3/papers.cfm ?abstract_id=2136955, archived at http://perma.cc/8JC2-LXCY; see also James Bessen et al., The Private and Social Costs of Patent Trolls (Bos. Univ. Sch. of Law, Law \& Econ. Research Paper No. 11-45, 2011), available at http://papers.ssrn.com/sol3/papers.cfm ?abstract_id=1930272, archived at $\mathrm{http}: / /$ perma.cc/87BL-YUS5.

92 See, e.g., Michael J. Burstein, Rules for Patents, 52 WM. \& MARY L. REV. 1747, 1747-48 (2011); Orin S. Kerr, Rethinking Patent Law in the Administrative State, 42 WM. \& MARY L. REV. 127, 127-33 (2000); Clarisa Long, The PTO and the Market for Influence in Patent Law, 157 U. PA. L. ReV. 1965, 1966 (2009); Craig Allen Nard, Deference, Defiance, and the Useful Arts, 56 OHIO ST. L.J. 1415, 1417 (1995); Arti K. Rai, Engaging Facts and Policy: A Multi-Institutional Approach to Patent System Reform, 103 ColuM. L. REV. 1035, 1036-41 (2003); Melissa F. Wasserman, The Changing Guard of Patent Law: Chevron Deference for the PTO, 54 WM. \& MARY L. REV. 1959, 2013-18 (2013); Melissa F. Wasserman, The PTO's Asymmetric Incentives: Pressure to Expand Substantive Patent Law, 72 OHIO ST. L.J. 379, 380-86 (2011).

Good historical work has been done on the political interest groups involved in making patent policy in the nineteenth and early twentieth century railroad industry. See Steven W. Usselman, Regulating Railroad Innovation: Business, Technology, AND POLITICS IN AMERICA, 1840-1920, at 1-14 (2002); Steven W. Usselman \& Richard R. John, Patent Politics: Intellectual Property, the Railroad Industry, and the Problem of Monopoly, 18 J. POL'y Hist. 96, 97-99 (2006); see also MARGARET SUSAN THOMPSON, THE "SPIDER WeB": CONGRESS AND LOBBYING IN THE AgE OF GRANT 33-69 (1985). There is also a growing body of scholarship on capture in the development of international IP law and TRIPS. See Susan K. Sell, Private Power, Public Law: The Globalization of Intellectual Property Rights 1-29 (2003); Margot E. Kaminski, The Capture of International Intellectual Property Law Through the U.S. Trade Regime, 87 S. CAL. L. REV. 977, 977-78 (2014). 
Part of the explanation for this is historical. The PTO is not one of the great regulatory edifices of progressivism and the New Deal, such as the Food \& Drug Administration, the Securities Exchange Commission, or the GlassSteagal Act. Rather, it has been around since the early national period. Further, it has historically been blessed with an aura of specialization and expertise that tended to emphasize the role of producers while minimizing the role of the courts. When the patent prosecution process did get into the courts it was mainly through infringement lawsuits filed after patents were issued and invalidity was raised as a defense.

The absence of a consumer welfare prescription in patent law is troublesome. Consumer interests should be just as central to intellectual property law as they are to antitrust. Just as in antitrust, consumers have the correct set of incentives. They tend to profit from a well-functioning patent system, furthering innovation that expands output and increases quality and variety, while reducing costs. More generally, consumers profit from economic growth, and innovation is growth's largest driver. ${ }^{93}$ Further, consumers tend to be injured by restrictive rules that facilitate exclusion or collusion without producing offsetting benefits in the form of increased incentives to innovate. ${ }^{94}$

Over history, Congress has more-or-less consistently ratcheted up patent protection at the behest of producer groups. For example, in 1952 it responded to a series of Supreme Court rulings limiting patent coverage to acts of "genius" by redefining patentability in terms of merely "nonobvious" subject matter. ${ }^{95}$ That same year it limited the judge-made doctrine of patent misuse. ${ }^{96}$ Then, in 1988, Congress amended the Act to provide further protection against patent misuse claims. ${ }^{97}$ These limitations on misuse served to limit the scope of antitrust liability while expanding the power of patents. ${ }^{98}$

Even today, debates about patent reform and the proper response to the recent explosion of infringement lawsuits tend to be waged among producers, with consumer interests on the sidelines. In areas such as pharmaceutical patents on primary ingredients the patent system works relatively well and most participants oppose significant change. By contrast, firms operating in information technologies want reform. This has little to do with consumer

93 See infra notes 158-63 and accompanying text.

94 See Herbert J. Hovenkamp, Consumer Welfare in Competition and Intellectual Property Law, COMPETITION POL'Y INT'L, Autumn 2013, at 53, 53-55 (developing this point).

95 Patent Act of 1952, Pub. L. No. 82-593, ch. 950, 66 Stat. 792 (codified as amended at 35 U.S.C. $\S 103$ (2012)). On the 1952 Patent Act, see HovENKAMP, supra note 4, at 184-205; John F. Duffy, Inventing Invention: A Case Study of Legal Innovation, 86 TEX. L. REV. 1, 33-43 (2007).

9635 U.S.C. $\$ 271(\mathrm{~d})(2012)$.

97 See id. $\$ 271(\mathrm{~d})(4)-(5)$ (expanding the list of practices not to be regarded as misuse).

98 See, e.g., Ill. Tool Works, Inc. v. Indep. Ink, Inc., 547 U.S. 28, 40-43 (2006) (applying the misuse rule on patent ties to antitrust law). 
interests as such, however. Rather, the patent system as we currently have it has become a deadweight loss on firms operating in markets for information technologies, often yielding private costs that far exceed benefits. ${ }^{99}$ When consumer interests are recognized in the judicial process, it is in antitrust cases, not patent cases. ${ }^{100}$

This history of producer capture makes statutory silence all the more important in areas where competition policy is concerned. A prime example is pay-for-delay settlements in the pharmaceutical industry, which were the subject of the Supreme Court's Actavis decision. ${ }^{101}$ While the Patent Act authorizes production licenses, it says nothing about naked payments to keep a rival out of the market. As a matter of competition policy, the case against large pay-for-delay settlements is overwhelming. Indeed, any equilibrium payfor-delay settlement is highly likely to harm consumer welfare. ${ }^{102}$ What many of these settlements do is create small duopoly cartels between a pioneer drug manufacture and an agreeing generic that effectively shields the patent from outside challenge, no matter how weak it is. ${ }^{103}$ This is why the Supreme Court acted correctly when it held that such agreements could be condemned without necessarily inquiring into questions about patent validity or infringement. Significantly, however, Actavis is entirely a matter of statutory interpretation. As a consistent history of Patent Act capture shows, if Congress wishes, it can always amend the Patent Act to permit such settlements.

An important regulatory principal about statutory construction is at work here. Courts are obliged to apply explicit statutory mandates even if they are a consequence of capture. But when capture is a realistic threat and harm is

99 See BESSEN \& MEURER, supra note 86, at 14-16, 95-119. On the divergent interests of producer groups, see PhRMA Commends House of Representatives, PHRMA (Dec. 5, 2013), http://www.phrma.org/phrma-statement-house-passage-of-innovation-act, archived at http://perma.cc/DW9N-K7H5 (discussing pharmaceutical industry trade group opposing passage of the Innovation Act); CEA Welcomes Passage of the Innovation Act, CEA (Dec. 5, 2013), http://www.ce.org/News/News-Releases/Press-Releases/2013-Press-Releases /CEA-Welcomes-Passage-of-the-Innovation-Act.aspx, archived at http://perma.cc/J4GBB4QP (discussing electronics industry trade group supporting passage of the Innovation Act). But see David Orozco \& James G. Conley, Friends of the Court: Using Amicus Briefs to Identify Corporate Advocacy Positions in Supreme Court Patent Litigation, 2011 U. ILL. J.L. TECH. \& POL'Y 107, 125-26 (noting that most large firms support weaker patent rights).

100 See, e.g., In re DDAVP Direct Purchaser Antitrust Litig., 585 F.3d 677, 695 (2d Cir. 2009) (granting antitrust standing to consumers to challenge pay-for-delay settlement); see also Ritz Camera \& Image, LLC v. SanDisk Corp., 700 F.3d 503, 508 (Fed. Cir. 2012) (resembling Walker Process).

${ }^{101}$ See FTC v. Actavis, Inc., 133 S. Ct. 2223, 2227, 2238 (2013). See infra notes 11734 and accompanying text.

102 See infra notes 243-45 and accompanying text; see also Aaron Edlin et al., Actavis and Error Costs: A Reply to Critics, ANTITRUST SOURCE, Oct. 2014, at 1, 7-8, available at $\mathrm{http}: / /$ papers.ssrn.com/sol3/papers.cfm?abstract_id=2448530, archived at http://perma.cc /H28X-ZNYB.

103 See infra notes 121-23. 
apparent, statutes that are silent on the issue or ambiguous should be construed against the special interest group that controls the process. Bad rules that run contrary to this group's interests are likely to be changed. On the other hand, a bad decision that favors the interest group in charge is unlikely ever to be changed because those on the other side lack the political organization. ${ }^{104}$

\section{Antitrust Capture: The Government as Buyer}

Antitrust is hardly immune from capture, but there are important differences that serve to limit the role of capture in antitrust adjudication. One is the spare and highly general language of most of the statutory provisions. The Sherman Act speaks very simply of practices that "restrain trade" or "monopolize." 105 The Clayton Act is a little more specific, condemning tying, exclusive dealing, and mergers "where the effect ... maybe substantially to lessen competition," but saying very little more. 106 The Robinson-Patman Act, passed during the Great Depression as a lengthy amendment to Section 2 of the Clayton Act, is an important exception, intended to protect mainly small family run grocery stores at the expense of larger more efficient sellers and the public. ${ }^{107}$ But widespread recognition of its special interest nature has led to suppression of its use, by both the Antitrust Division ${ }^{108}$ and the Supreme Court. ${ }^{109}$ The balance of the antitrust laws states a very general concern with competition and places the onus for interpretation on judges. Federal judges certainly have ideologies or preconceptions, but they are not actively lobbied, their ex parte contacts in a particular case are severely limited, and they have lifetime tenure, which shields them from the most overt political processes.

The federal enforcement agencies are certainly more political, but one thing that distinguishes them from most other government agencies is their highly general, multi-sector mandate. Antitrust applies to all commercial activity affecting interstate commerce that has not been exempted. Further, the legal principles, such as market definition or assessment of power, apply

${ }^{104}$ For particular application to copyright law, see Bohannan, supra note 86 , at $571-$ 72. More generally, see EINER ElHauge, Statutory DeFault Rules: How to INTERPRET UNCLEAR LEGISLATION 1-22 (2008).

10515 U.S.C. $\S \S 1-2(2012)$.

10615 U.S.C. $\$ \S 14,18(2012)$.

10715 U.S.C. $\S 13$ (2012). On the legislative history and statutory intent, see 14 HovenKAMP supra note 21, ๆף 2302, 2331, 2333.

108 See U.S. DeP'T OF JuSTICE, REPORT ON THE RoBInSON-PATMAN ACt 251-59 (1977) (announcing Antitrust Division's intent to no longer enforce the statute); see also H.R. REP. No. 91-1617, at 34-35 (1970).

109 See, e.g., Great Atl. \& Pac. Tea Co. v. FTC, 440 U.S. 69, 83 n.16 (1979) (noting the need to interpret the Robinson-Patman Act so as to minimize inconsistency with the Sherman Act). 
across the full range. As a result, the idea that any particular industry can capture an antitrust agency is doubtful. ${ }^{110}$

To be sure, there may be offsetting considerations. For example, the government is a market participant as well as an enforcer. It is a very large purchaser of military equipment and supplies, office equipment, vehicles and fuel, and pharmaceutical drugs, particularly through federally administered health care programs. One interesting question is whether a somewhat different type of capture occurs. Perhaps the government's role as a market participant biases its decision making when acting as an enforcer.

Historically, the empirical case for such distortion seems weak. For example, the government has always been a very large purchaser of leather shoes, principally for the military, but that did not stop it from using antitrust law in Brown Shoe Co. v. United States to protect higher-cost, smaller firms by restricting the efficiencies that a larger but by no means monopolistic firm could obtain from a merger. ${ }^{111}$ The government also frequently opposed vertical integration in industries in which it purchased products, even though the consequence was almost certainly higher prices in the markets in question, ${ }^{112}$ and it challenged monopolization in the aluminum industry on the theory that Alcoa continuously expanded its capacity in anticipation of greater market demand, a price and cost reducing strategy. ${ }^{113}$ Indeed, the government

110 See Jonathan B. Baker, Sector-Specific Competition Enforcement at the FCC, 66 N.Y.U. AnN. Surv. AM. L. 413, 415 \& n.13 (2011); Simon J. Evenett, Competition Advocacy: Time for a Rethink?, 26 Nw. J. INT'L L. \& BUS. 495, 498 (2006); Michel Kerf \& Damien Geradin, Controlling Market Power in Telecommunications: Antitrust vs. SectorSpecific Regulation-An Assessment of the United States, New Zealand and Australian Experiences, 14 Berkeley TECH. L.J. 919, 931 (1999); see also StUART M. CheMtoB, U.S. DeP'T OF Justice, The Role of COMPETITION AGENCIES IN REGULATED SECTORS 3-7 (2007), available at http://www.justice.gov/atr/public/speeches/225219.htm, archived at http://perma.cc/SC3M-BVGB.

${ }^{111}$ See Brown Shoe Co. v. United States, 370 U.S. 294, 344 (1962). For further information, see the district court's opinion at 179 F. Supp. 721,738 (E.D. Mo. 1959) (citing the post-merger firm's lower costs as a reason for condemning the merger); see also Brief for the United States at 48, Brown Shoe Co. v. United States, 370 U.S. 294 (1961) (No. 4) (arguing that the merger would permit the post-merger firm to "sell its own product at a significantly lower price than the nonintegrated independent retailer can obtain for a comparable product.... The conclusion was inevitable that the advantages the merged company would have over its smaller retailing competitors would be so great as to threaten to become decisive.").

112 See, e.g., United States v. U.S. Steel Corp., 251 U.S. 417, 442-43 (1920); United States v. E.I. du Pont de Nemours \& Co., 353 U.S. 586, 608-11, 640-41 (1957) (challenging DuPont's partial stock acquisition of GM on the theory that GM would be able to obtain preferred treatment in du Pont provided automobile finishes and fabrics); see also United States v. Reading Co., 253 U.S. 26, 27-28 (1920) (condemning exclusive dealing under Sherman Act); United States v. Reading Co., 226 U.S. 324, 373 (1912) (condemning an acquisition).

113 United States v. Aluminum Co. of Am. (Alcoa), 148 F.2d 416, 437-38 (2d Cir. 1945). 
obtained a decree that forbade Alcoa from bidding on aluminum plants that the United States government sold after the war, certainly reducing the amount of revenue that the government obtained. ${ }^{114}$ For a half-century, the antitrust enforcement agencies, particularly the Federal Trade Commission, engaged in relentless attempts to condemn efficient price discrimination practices under the Robinson-Patman Act. The result was clearly to increase the price of several products for which the government was a very large purchaserincluding petroleum, foodstuffs, vehicles, gasoline, tires, automobile parts, and the like. In other cases they sought rules whose higher costs would apply to government purchasers, whether or not the specific items in that case were subject to government purchase. ${ }^{115}$ This record contrasts with the record of a sector-specific agency such as the United States Food \& Drug Administration, where there is some evidence that the agency has responded to high purchase

${ }^{114}$ See Herbert Roback, Monopoly or Competition Through Surplus Plant Disposal? The Aluminum Case, 31 CORNELL L. Q. 302, 314-18 (1946).

115 See Great Atl. \& Pac. Tea Co. v. FTC, 440 U.S. 69, 83 (1979) (seeking to condemn large chain store for bargaining for lower prices from suppliers); FTC v. Borden Co., 383 U.S. 637, 641 n.4, 643 (1966) (seeking to require Borden to charge the same higher price to chain stores as to individually owned stores); FTC v. Morton Salt Co., 334 U.S. 37, 47 (1948) (attacking Morton Salt's system of quantity discounts); Fred Meyer, Inc. v. FTC, 359 F.2d 351 (9th Cir. 1966) (pursuing promotional allowances in grocery retailing), rev'd on other grounds, 390 U.S. 341 (1968); United Biscuit Co. of Am. v. FTC, 350 F.2d 615 (7th Cir. 1965), cert. denied, 383 U.S. 926 (1966) (similar); Goodyear Tire \& Rubber Co. v. FTC, 101 F.2d 620 (6th Cir. 1939), cert. denied, 308 U.S. 557 (1939); Ark. Wholesale Grocers' Ass'n v. FTC, 18 F.2d 866 (8th Cir. 1927) (condemning grocers' association boycott of suppliers who sold to chain store retailers at the same price as they sold to the defendant wholesalers); United States v. S. Cal. Wholesale Grocers' Ass'n, 7 F.2d 944 (S.D. Cal. 1925) (similar, Justice Department lawsuit); Joseph A. Kaplan \& Sons, Inc., 63 F.T.C. 1308, 1347 (1963) (seeking condemnation of a promotional allowance); Tri-Valley Packing Ass'n v. FTC, 329 F.2d 694, 703 (9th Cir. 1964) (condemning discounting in market acknowledged to be "highly competitive"); Standard Oil Co., 41 F.T.C. 263 (1945), modified and aff'd, 173 F.2d 210, 217 (7th Cir. 1949) (stating that there should be liability if defendant "sells to a wholesaler it knows or ought to have known . . . is using or intends to use [the wholesaler's] price advantage to undersell [the] prices made to ... retailers"), rev'd on other grounds, 340 U.S. 231 (1951); see also FED. TRADE COMM'N, CHAIN Stores: Final Report on the Chain-Store Investigation, S. Doc. No. 74-4, at 78 (1935) (documenting extent to which chain stores undersold family owned grocers). On automobile parts, see Mid-South Distribs. v. FTC, 287 F.2d 512 (5th Cir. 1961); Am. Motor Specialties Co. v. FTC, 278 F.2d 225 (2d Cir. 1960); Standard Motor Prods., Inc. v. FTC, 265 F.2d 674 (2d Cir. 1959); see also Purolator Prods., Inc. v. FTC, 352 F.2d 874 (7th Cir. 1965) (automobile air filters); Alhambra Motor Parts, 68 F.T.C. 1039 (1965) (automobile parts buyers' cooperative). For other studies, see Advisory Opinion No. 147, 72 F.T.C. 1050, 1050-51 (1967) (stating that in delivered pricing system trucks should return empty rather than receiving a price allowance for agreeing to carry cargo and opining that "it is highly doubtful that the defense of cost justification ... would be available"); Minneapolis-Honeywell Regulator Co., 44 F.T.C. 351, 394 (1948) (rejecting the use of cost studies to justify discriminatory prices as cost justified), rev'd on other grounds, 191 F.2d 786 (7th Cir. 1951). 
prices for pharmaceutical drugs by reducing standards for both pioneer drugs and generics. ${ }^{116}$

In sum, while the government is in fact a very large market participant, there is no good empirical case to be made that this has affected antitrust policy in the non-sector-specific antitrust enforcement agencies. For much of the history of antitrust law, the government promoted antitrust rules that were either indifferent to cost savings or imposed higher costs on the very products that it purchased.

When the government participates in markets subject to the antitrust laws it is typically as a consumer rather than producer. Given that "consumer welfare" is the articulated goal of the antitrust laws, the interests of the government as a consumer are presumably aligned with the interests of the government as an enforcer; it wants what makes consumers best off.

Perhaps this is too simplistic. When the government purchases drugs its vision may in fact be myopic, overwhelmed by short run costs that come out of the current budget. This may lead it to discount the impact of long-term innovation, which might benefit consumers more, but over a longer period of time. For example, perhaps the federal government operates as a buyer in pharmaceutical markets to encourage generic drug use, and this pro-generic bias spills into its antitrust enforcement policy as well. As a result, the tradeoff between immediate low prices and long run investment is negative.

In any event, in order to make this determination we would first have to conclude that there is something to trade off. For example, if there were any actual evidence that condemning pay-for-delay pharmaceutical settlements reduces consumer welfare by suppressing innovation, then the government might be obliged to balance. Based on present information, however, the evidence is quite overwhelming that condemning pay-for-delay settlements increases consumer welfare greatly in the short run by leading to lower drug prices and more widespread use. The idea that condemning such settlements impairs the ex ante incentive to innovate and that the social costs of this impairment exceed the benefits of increased access has no empirical support.

116 See James T. O'Reilly, Losing Deference in the FDA's Second Century: Judicial Review, Politics, and a Diminished Legacy of Expertise, 93 CORNELL L. REV. 939, 956960 (2008); see also Donald W. Light et al., Institutional Corruption of Pharmaceuticals and the Myth of Safe and Effective Drugs, 41 J.L. MED. \& ETHICS 590, 592 (2013). Other evidence, mainly from an earlier period, suggests just the contrary-namely that FDA officials were overly cautious in approving new drugs because they were so concerned about highly publicized drug failures. See HENRY G. GRABOWSKI \& JOHN M. VERNON, THE Regulation of Pharmaceuticals: BALANCING THE BENEFITS AND Risks 7 (1983). O'Reilly believes the change occurred during the administration of George W. Bush. See O'Reilly, supra, at 940. 


\section{Patent Regulation AND the ACtaVis DeCision}

The Hatch-Waxman Act and Supreme Court's Actavis decision, discussed in more detail later, illustrate these regulatory principles. 117 "Pay-for-delay" settlements, in which a patentee pays an infringement defendant a large sum to stay out of the patentee's market, appear to be a unique feature of the HatchWaxman grant of secondary exclusivity to the first generic firm to challenge a pioneer's patent. ${ }^{118}$ A congressional overruling of Actavis, should that occur, need not even take the form of a general Patent Act amendment. It could be an amendment to Hatch-Waxman itself, applying only to situations that the provision covers. In the case of pharmaceuticals, there is a strong history of producer control over the drug creation and approval system. Patentees in other markets need not worry.

Briefly, the Hatch-Waxman Act provisions at issue in Actavis were designed to facilitate the entry of generic drug manufacturers into a market when a pioneer branded drug entered the public domain because its patents had either expired or been invalidated. Generic entry is more likely to occur if someone is rewarded for taking the first entry risk. One problem with generic entry is that often if everyone can enter, no one will. Bioequivalent generics are chemically identical, making them largely fungible with one another. As a result competition among generics drives prices to the competitive level, making immediate entry by multiple firms unpromising. The compromise position envisioned by the statute is to permit a single generic to enter first, with its own 180-day period of "shared" exclusivity with the original branded manufacturer. ${ }^{119}$ Such entry typically produces lower prices quickly. After the first generic is produced for six months, other generics can enter the market, driving prices down to as little as $20 \%$ of pre-generic-entry prices. ${ }^{120}$

Congress did not foresee the possibilities of abuse that have emerged. The right of generic exclusivity vis-a-vis everyone except the pioneer creates a

${ }^{117}$ FTC v. Actavis, 133 S. Ct. 2223, 2227-29 (2013).

118 The majority and dissenters in Actavis debated this proposition, but the majority was clearly correct on the facts. See Herbert Hovenkamp, Anticompetitive Patent Settlements and the Supreme Court's Actavis Decision, 15 MinN. J.L. SCI. \& TECH. 3, 1516 (2014).

119 See 21 U.S.C. $\S 355(\mathrm{j})(5)(\mathrm{B})(\mathrm{iv})(2012)$. The Supreme Court described the process briefly in Actavis, 133 S. Ct. at 2228-29. See 12 HovenKAMP, supra note 21, \ 2046c; C. Scott Hemphill \& Mark A. Lemley, Earning Exclusivity: Generic Drug Incentives and the Hatch-Waxman Act, 77 ANTITRUST L.J. 947, 952 (2011); Hovenkamp, supra note 118, at $8-10$.

${ }^{120} \mathrm{See}$ ORG. FOR ECON. CO-OPERATION \& DEV., DiReCtORATE FOR FinANCIAL AND ENTERPRISE AfFAIRS: GENERIC PHARMACEUTICALS 4 (2014), available at http://www.ftc.gov/system/files/attachments/us-submissions-oecd-other-international-comp etition-fora/generics_us_oecd.pdf, archived at http://perma.cc/92PV-GJYQ (updating statistics on pharmaceutical pricing in the wake of generic entry); see also Steven Tenn \& Brett W. Wendling, Entry Threats and Pricing in the Generic Drug Industry, 96 REV. ECON. \& STAT. 214, 219-27 (2014) (comparing based on market size). 
duopoly with absolute legal protection from challenge or new entry until 180 days after the generic begins producing, no matter how weak the pioneer's patent. If there is any doubt about a question of patent validity or infringement, the joint maximizing solution for the pioneer and the first entrant is to divide the maximum profits available under this duopoly. The price and output determined by a well-functioning cartel is identical to the price and output that a monopolist would determine. ${ }^{121}$ Under the pay-for-delay settlement, the 180day clock does not run because the generic is not producing anything. The more likely that the patent will not withstand judicial scrutiny, the greater amount the pioneer will be willing to pay for this agreement. By contrast, if no payment for delay is permitted, as the Hatch-Waxman legislation contemplated, then the parties will bargain for an earlier entry date, thus benefitting consumers more. ${ }^{122}$

121 See Herbert Hovenkamp, Federal Antitrust Policy: The LaW of COMPETITION AND ITS PRACTICE $\$ 4.1-.2$ (4th ed. 2011).

122 The amount that the pioneer is willing to pay is typically many times more than the amount that the generic is willing to accept as an inducement to stay out of the market. This makes settlements highly likely to occur, whether or not payments for delay are permitted. See Ruben Jacobo-Rubio et al., Generic Entry, Pay-for-Delay Settlements, and the Distribution of Surplus in the US Pharmaceutical Industry 3 (Oct. 7, 2014) (unpublished manuscript), available at http://papers.ssrn.com/sol3/papers.cfm?abstract_id $=2481908$, archived at http://perma.cc/L2KV-87TP (measuring high value of pay-for-delay settlements). One important finding is that pioneer drug makers value entry deterrence by roughly $\$ 4.6$ billion, while generics value the right to enter at about $\$ 236.8$ million. Id. This provides enormous bargaining room for an exclusion payment once the parties have come fairly close to an understanding about patent value. See id. at 4; see also Bruce H. Kobayashi et al., Actavis and Multiple ANDA Entrants: Beyond the Temporary Duopoly 3 (George Mason Univ. Law \& Econ. Working Paper Series, Paper No. 14-62, 2014), available at http://papers.ssrn.com/sol3/papers.cfm?abstract_id=2508094, archived at http://perma.cc/65PX-PVGD. The authors note that if a patent is found invalid a duopoly exists only for the 180 days of generic exclusivity; after that other generics can enter. $I d$. at 3-4. This makes a pre-judgment settlement even more valuable for the pioneer, because anticipated losses from generic competition will be higher than the settlement cost. Id. at 4 . The authors conclude, oddly, that this indicates a fuller inquiry into patent validity. $I d$. at 14-15. But their model indicates precisely the opposite. It suggests that the likelihood of a settlement without the need of a reverse payment is even higher. Further, generic entry will occur earlier if no payment is made. All things being equal, a settlement without a payment-for-delay is always better from consumers' perspective than a settlement with one. At the same time, the model also indicates that even when no payment is made, a settlement can harm consumers. For example, a risk-averse generic will bargain for delayed but permitted entry rather than face the likelihood that the patent will be declared valid and infringed and they will not be able to enter at all prior to patent expiration; or that it will be declared invalid, and they will have only 180 days of exclusive production in competition with the pioneer alone. The Kobayashi model thus suggests that the Supreme Court, if anything, was not sufficiently harsh. The welfare effects of a settlement with a large reverse payment are generally worse than a settlement without a reverse payment, but even some of those without a reverse payment harm consumers. 
One important thing about pay-for-delay settlements is that they are favored by both the pioneer and the first generic. Dividing the monopoly proceeds is virtually always more profitable than competing, even within a duopoly. The only way that the two firms could hope to duplicate this return would be if they fixed prices after the generic started producing. But this would be unlawful collusion under the antitrust laws and even a criminal offense.

In defense, settlement participants point out that if the patent is valid and infringed, the generic would lose its lawsuit anyway and the result would be the patentee's continued sole production under the patent, or the monopoly result. The Actavis dissenters emphasized this point. ${ }^{123}$ As a result, a pay-fordelay settlement on an absolutely valid patent would generate a result no worse than litigation would achieve, provided that the duration of the pay-fordelay settlement is no longer than the remaining duration of the patent in question. This is where the "scope of the patent" issue arises, because the settlement agreements typically terminate prior to the expiration of the patent.

If the "scope of the patent" rule that the Actavis dissenters favored were to become law-with scope measured by the remaining duration of the patentthen the equilibrium pay-for-delay agreement would postpone generic entry right up to the patent's expiration. ${ }^{124}$ The patent provides a monopoly stream that lasts for its duration, and the joint-maximizing position for the litigating parties would be to take full advantage of this stream. The only indeterminacy is the size of the payment, which would vary with the parties' predictions of the outcome of the patent litigation.

Pharmaceutical drug patents on pioneer molecules are very robust, and for these we would not ordinarily expect large pay-for-delay agreements. It is no coincidence that most pay-for-delay settlements involve secondary or "evergreened" patents on new dosages, new treatments, or new combinations of well-established drugs. ${ }^{125}$ Some may also involve what has come to be known as "product hopping," which occurs when a pioneer switches support away from an older version of a drug in favor of a newer version. ${ }^{126}$ Product hopping has produced antitrust complaints of anticompetitive design

123 See Actavis, 133 S. Ct. at 2238-39 (Roberts, C.J., dissenting).

${ }^{124}$ See Hovenkamp, supra note 94, at 60.

125 See Fed. TRade Comm'n, Generic Drug Entry Prior to Patent Expiration: AN FTC STUDY 16 (2002), available at www.ftc.gov/os/2002/07/genericdrugstudy.pdf, archived at http://perma.cc/HN4X-TSXR (summarizing cases); Rebecca S. Eisenberg, The Role of the FDA in Innovation Policy, 13 Mich. Telecomm. \& TeCH. L. ReV. 345, 354 (2007).

${ }^{126}$ See Michael A. Carrier, A Real-World Analysis of Pharmaceutical Settlements: The Missing Dimension of Product Hopping, 62 FLA. L. REV. 1009, 1030-36 (2010); Jessie Cheng, An Antitrust Analysis of Product Hopping in the Pharmaceutical Industry, 108 Colum. L. Rev. 1471, 1472, 1787-88 (2008); M. Sean Royall et al., Antitrust Scrutiny of Pharmaceutical "Product Hopping," 28 ANTITRUST 71, 71-72 (2013). 
changes. ${ }^{127}$ When generic entrants actually pursue patent infringement litigation to completion these patents end up being declared invalid or infringed more than $70 \%$ of the time. ${ }^{128}$ Prohibiting large pay-for-delay settlements will force patentees to litigate against generics or perhaps give them a production license.

The debate between the Actavis majority and dissenters illustrates two different approaches to the competitive analysis of post-issuance patent practices. As a matter of antitrust law, a pay-for-delay settlement is a naked market division agreement. There is no joint production or distribution, or sharing of technology or information. The pioneer is simply paying the generic to stay out of the market for the term specified in the agreement. This distinguishes pay-for-delay settlements from most others. Further, while production licenses are expressly authorized by the Patent Act, and are a common way of settling patent infringement cases, naked exclusion payments are not authorized by either the Patent Act or the Hatch-Waxman Act.

The Actavis dissenters believed such agreements were impervious to antitrust challenge so long as they fell within the patent's scope. Of course, the agreement would not be within the patent's scope if the patent were invalid or uninfringed, but historically the courts have not considered these issues when analyzing settlement agreements unless there were clear abuses. If the term of the agreement extended beyond the life of the patent, then it would exceed the patent's scope whether or not the patent was valid or infringed.

Over a long history the federal courts have followed a policy of encouraging settlements of patent infringement suits. They have been reluctant to dive into questions of validity or infringement simply when determining whether a settlement should be approved. The general assumption in these cases, however, is that there was true adversity between the parties, the patentee seeking to enforce its patent and the defendant seeking to avoid it or limit its costs. For example, the Supreme Court has concluded that an important test for a settlement was whether there were "legitimately conflicting" litigation claims. ${ }^{129}$ That is not the case in Hatch-Waxman pay-

127 See, e.g., In re Suboxone (Buprenorphine Hydrochloride and Naloxone) Antitrust Litig., No. 13-MD-2445, 2014 WL 6792663, at *42 (E.D. Pa. Dec. 3, 2014) (sustaining antitrust complaint); see also New York v. Actavis, PLC, No. 14 Civ. 7473, 2014 WL 7015198, at*1 (S.D.N.Y. Dec. 11, 2014) (granting preliminary injunction).

128 FED. TRADE COMM'N, supra note 125, at vi (demonstrating that generic applicants prevailed in seventy-three percent of the litigated infringement cases); see also C. Scott Hemphill \& Bhaven Sampat, Drug Patents at the Supreme Court, 339 SCIENCE 1386, 1387 (2013). For litigated patents generally, see John R. Allison \& Mark A. Lemley, Empirical Evidence on the Validity of Litigated Patents, 26 AIPLA Q.J. 185, 194, 205-06 (1998) (finding general invalidity rates of litigated patents in the forty to fifty percent range).

${ }^{129}$ Standard Oil Co. (Ind.) v. United States, 283 U.S. 163, 171 (1931); see also Asahi Glass Co. v. Pentech Pharm., Inc., 289 F. Supp. 2d 986, 991-92 (N.D. Ill. 2003) (Posner, J.) ("Only if a patent settlement is a device for circumventing antitrust law is it vulnerable to an antitrust suit. Suppose a seller obtains a patent that it knows is almost certainly invalid (that is, almost certain not to survive a judicial challenge), sues its competitors, and 
for-delay settlements where both the patentee and the generic are made better off by the settlement than by generic production.

The Court's strong preference for settlement has resulted in some clearly anticompetitive arrangements, such as the infringement settlement in Bement that included a provision fixing product prices. ${ }^{130}$ Actavis restates a point that the Supreme Court had previously embraced but inconsistently applied: patent settlements containing anticompetitive provisions that are not authorized by the Patent Act should receive closer scrutiny than provisions that are authorized. ${ }^{131}$

By contrast, the majority took an approach that was more realistic about the regulatory process that governs the patent systems. First of all, while the Patent Act expressly authorizes production licenses it nowhere permits naked market division agreements that are not attached to simultaneous production, and neither does the Hatch-Waxman Act. In most patent infringement cases outside the Hatch-Waxman context the infringement defendant pays a license fee to the patentee for a license to produce under the patent. Significantly, such license agreements are expressly authorized by the Patent Act and are lawful whether or not they are the outcome of infringement litigation.

While the Court required rule of reason treatment for Actavis-style payfor-delay settlements, this meant mainly that the burden of proving power and anticompetitive effects were on the plaintiff; however, both could be proven by truncated evidence. The Court observed that a large payment for delay could provide good evidence of market power, ${ }^{132}$ as well as anticompetitive effects. ${ }^{133}$ The Court did not alter the standard rule of reason approach that once the plaintiff has shown power and anticompetitive effects, then the burden shifts to the defendant to prove a defense. ${ }^{134}$

settles the suit by licensing them to use its patent in exchange for their agreeing not to sell the patented product for less than the price specified in the license. In such a case, the patent, the suit, and the settlement would be devices-masks-for fixing prices, in violation of antitrust law.").

${ }^{130}$ See Bement v. Nat'l Harrow Co., 186 U.S. 70, 94-95 (1902); see also infra notes 260-62 and accompanying text.

${ }^{131}$ See, e.g., United States v. Singer Mfg. Co., 374 U.S. 174, 175 (1963) (disapproved settlement agreement involving pooling plus the exclusion of third parties); HartfordEmpire Co. v. United States, 323 U.S. 386, 435 (1945) (horizontal customer restrictions); United States v. Masonite Corp., 316 U.S. 265, 277 (1942) (similar); see also Palmer v. BRG, Inc., 498 U.S. 46, 48-50 (1990) (per curiam) (holding that territorial division agreement established under trademark and copyright license agreement was per se unlawful).

132 See FTC v. Actavis, 133 S. Ct. 2223, 2235-36 (2013).

133 See id.

${ }^{134}$ See infra notes 223-26 and accompanying text. 


\section{PATENT AND ANTITRUST APPROACHES TO COMPETITION AND INNOVATION: COMPARATIVE ADVANTAGE}

The patent and antitrust systems have different structures and different histories. Both affect how competition and innovation issues are handled. First, while antitrust law's broad focus on competition has compelled antitrust courts to consider innovation issues, the reverse is rarely true. Second, the open-ended nature of the antitrust laws and their mandate to protect competition has directed litigants, their experts, and the academy to develop a large empirical literature on the competitive effects of various practices. By contrast, the patent code is much more specific and never invites such empirical query. As a result the empirical literature on how the patent system functions in relation to innovation goals is not well developed and, in any event, seldom employed in litigation. A critical aspect of that difference is the Patent Act's general insensitivity to market diversity, even though such diversity affects the rate and dissemination of innovation at least as much as it affects the robustness of competition. Finally, the creation of the Federal Circuit as an exclusive appellate tribunal for patent cases has exacerbated myopic analysis of innovation issues.

\section{A. Nonreciprocal Accommodation}

At least since the passage of the Clayton Act in 1914, courts deciding antitrust cases have attempted to accommodate patent policy to competition policy. To be sure, courts are imperfect and they have sometimes wandered to extreme positions, but at least they have taken seriously the idea that competition and innovation policy are related to one another and must be metered together.

To illustrate, consider the antitrust rule that a product innovation cannot be unlawful, no matter how much it harms competitors through its success. ${ }^{135}$ The rule has nothing to do with patent law and is not based on any specific patent law doctrine. Nor does it require anything like the assertion of a patent law counterclaim or even invocation of the Patent Act. Rather the antitrust rule is rooted in antitrust law's own appreciation that innovation is part of competition, requiring courts to consider them together, often protecting innovation even when it tends to create or prolong monopoly. Even this rule must be metered to the specific market, however, in order account for situations where the cost of design changes is very low in relation to the harm that a network monopolist might cause. ${ }^{136}$ Other examples include the explicit

135 See, e.g., Allied Orthopedic Appliances, Inc. v. Tyco Health Care Grp. LP, 592 F.3d 991, 994 (9th Cir. 2010); see also 3B PHILliP E. AREEDA \& HERBERT HovenKAMP, ANTITRUST LAW 9776 (4th ed. 2015).

136 See John M. Newman, Anticompetitive Product Design in the New Economy, 39 FLA. ST. U. L. REV. 681, 693-94 (2012). 
recognition in merger policy that mergers may reduce innovation by eliminating highly innovative competitors, or that explicit restraints on innovation are an important concern of competition policy. 137

Patent law simply does not have this tradition except in a few areas that fall into patent law's outer boundaries. For example, patent "misuse" doctrine identified competitive concerns in patent licensing and enforcement, often exaggerating them considerably. But recent case law has virtually written the patent misuse doctrine out of existence. ${ }^{138}$ The Supreme Court has occasionally suggested that concerns about competition play a role in defining the scope of IP rights - for example, denying trade dress protection to functional uses. ${ }^{139}$

Patent law has operated in a much more myopic universe in which competition policy is rarely addressed except in the small subset of cases that expressly include an antitrust counterclaim or misuse defense. Indeed, in some cases an increase in competition is considered to be the "harm" that justifies patent law relief-precisely the opposite of the "antitrust injury" rule that refuses to condemn a practice unless harm to competition is shown. One example is the Federal Circuit's 2014 decision in Trebro v. Firefly. The court counted competition itself as patent harm justifying an injunction on an unpracticed patent that the plaintiff had acquired from an outside inventor. ${ }^{140}$ Injunctions are generally denied to non-practicing entities, but in this case the court held that the fact that the parties were competing served to justify an injunction. No antitrust issues were raised, but that is not surprising given that patent law decision making has never developed a culture of taking competition issues seriously.

Another situation where courts fail to consider impact on competition involves the use of "authorized generic" restrictions in settlements of patent infringement suits in the pharmaceutical industry. An "authorized generic" is one that is made by the patentee itself. No patent infringement is involved, because the patentee already owns the patent. An authorized generic typically is identical to the branded version in both active and inactive ingredients. They differ mainly in trademark and packaging. The courts have held repeatedly that a branded drug manufacturer is entitled to introduce its own authorized generic

137 See U.S. DeP'T of Justice \& Fed. Trade Comm'n, Horizontal Merger GUIDELINES II 1 (2010), available at http://www.justice.gov/atr/public/guidelines/hmg2010.html, archived at http://perma.cc/VN4H-JVF3; PHILlIP E. AREEDA \& HERBERT Hovenkamp, ANTitrust LAW 9ף 900.1a, 900.1c (Supp. 2015); Herbert Hovenkamp, Restraints on Innovation, 29 CARDOZO L. REV. 247, 252 (2007).

138 See Bohannan \& Hovenkamp, supra note 79, at 21-23.

${ }^{139}$ See, e.g., TrafFix Devices, Inc. v. Mktg. Displays, Inc., 532 U.S. 23, 34-35 (2001); see also Thomas F. Cotter, The Procompetitive Interest in Intellectual Property Law, 48 WM. \& MARY L. REV. 483, 506-20 (2006) (citing misuse doctrine and functionality limits on trade dress law as examples of competition concerns raised within IP policy).

140 Trebro Mfg., Inc. v. Firefly Equip., LLC, 748 F.3d 1159, 1170-71 (Fed. Cir. 2014); see infra notes 460-64 and accompanying text. 
into the market. ${ }^{141}$ The authorized generic can be a socially valuable price discrimination device, enabling the patentee to reach higher elasticity customers who are price sensitive, while retaining the brand for less price sensitive customers.

Even following Actavis, several decisions have upheld patent settlements in which a generic firm has agreed to delayed entry in exchange for the patentee's promise not to enter the market with an authorized generic. ${ }^{142}$ The "no authorized generic" clause increases prospective profits to the generic, and thus can serve to reduce the size or in some cases perhaps even eliminate a cash payment to the generic. The literature suggests that the entry of an authorized generic can reduce the first generic's output by half, and this is what one would ordinarily expect. The two generics are nearly identical, and if the firms have the same costs each would end up with roughly half of the market. The literature also suggests that post-entry generic prices are about $16 \%$ lower if an authorized generic comes into the market. ${ }^{143}$ For these reasons the patentee's promise not to enter with an authorized generic is very valuable to a prospective independent generic entrant.

Such a promise is valuable, however, for the same reason that any cartel agreement can be valuable to participants: one cartel member promises to restrain its own output in order to get market prices up. A "no authorized generic" provision is actually more anticompetitive and harmful to consumers than a payment for delay. The payment for delay is merely a wealth transfer between the patentee and generic. By contrast, the "no authorized generic"

${ }^{141}$ See Sanofi-Aventis v. Apotex Inc., 659 F.3d 1171, 1174-75 (Fed. Cir. 2011); Mylan Pharm., Inc. v. FDA, 454 F.3d 270, 271 (4th Cir. 2006); Teva Pharm. Indus. Ltd. v. Crawford, 410 F.3d 51, 52 (D.C. Cir. 2005).

142 See, e.g., In re Effexor XR Antitrust Litig., No. 11-5479, 2014 WL 4988410, at *26 (D.N.J. Oct. 6, 2014); In re Lipitor Antitrust Litig., No. 3:12-CV-02389 PGS, 2014 WL 4543502 , at $* 25$ (D.N.J. Sept. 12, 2014) (involving a provision in agreement under which patentee promised not to enter with authorized generic during 180-day exclusivity period was not a "payment" for delay and thus did not invoke Actavis doctrine); In re Loestrin 24 Fe Antitrust Litig., 45 F. Supp. 3d 180, 194 (D.R.I. 2014) (ruling that Actavis applied only to cash payments, which means that promises not to enter the market with an authorized generic could not be counted); In re Lamictal Direct Purchaser Antitrust Litig., 18 F. Supp. 3d 560, 570 (D.N.J. 2014) (similar). Compare In re Niaspan Antitrust Litig., 42 F. Supp. 3d 735, 751 (E.D. Pa. 2014) (settlement agreement provision preventing pioneer from entering with authorized generic could be counted together with other promises in determining existence of large reverse payment), with In re Nexium (Esomeprazole) Antitrust Litig., 968 F. Supp. 2d 367, 410-11 (D. Mass. 2013) (similar). See also Aaron S. Edlin et al., The Actavis Inference: Theory and Practice, 66 RUTGERS L. REV. (forthcoming 2015) (manuscript at 1-12), available at http://papers.ssrn.com/sol3/papers.cfm?abstract_id

$=2560107$, archived at http://perma.cc/2RRK-QZLK (critiquing these and other postActavis decisions).

143 See In re Effexor, $2014 \mathrm{WL} 4988410$, at *4; see also FED. TRADE COMM'N, AUTHORIZED GENERICS: AN INTERIM REPORT 1-2 (2009), available at www.ftc.gov /os/2009/06/P062105authorizedgenericsreport.pdf, archived at http://perma.cc/5LDF-9J4S. 
agreement is not merely a wealth transfer, it is also a cartel agreement that serves to reduce market output and keep prices higher than they would otherwise be. ${ }^{144}$ As a result, agreements restraining authorized generic entry should be treated more harshly than pay-for-delay settlements. After all, a payfor-delay settlement is not a license but, at most, an agreement to license in the future. By contrast, the no-authorized-generic agreement takes effect immediately. Because neither an IP license nor any kind of joint production is contemplated, these are simply naked market division agreements.

To be sure, sometimes increased competition should count as "injury" for patent infringement purposes. That would be true, for example, when a competitor is a direct infringer of a technology that a dominant firm is practicing. In any event, the Patent Act's expressly created right to bring an infringement action contains no exception for actions against competitors. But entitlement to an injunction is a matter of equitable principles and not an absolute right. To permit a dominant firm to acquire competing technology from an outside inventor and then use it to shut down a rival can cause considerable harm to competition without protecting any element of innovation, because the patent in question had already been invented by someone else.

\section{B. Uneven Empirical Research}

The unevenness of the economic literature on the antitrust and patent systems reflects fundamental differences in how the two systems approach economic policy. The theoretical and empirical literature on price theory, industrial organization, and competition is large and stretches across more than a century. The courts have generally paid attention, making antitrust the first area of significant judicial reliance on economic literature. ${ }^{145}$ The record reveals diverse impulses resulting from different economic theories, as well as differing ideas about the goals of antitrust law. For example, the post-New Deal era was dominated by an economic theory that strongly distrusted markets and had heightened fears about the competitive threats imposed by vertical integration, product differentiation, and intellectual property. ${ }^{146}$ The Warren Era in the 1960s was overly preoccupied with protecting smaller businesses from conduct that was presumed to be anticompetitive but was often efficient. ${ }^{147}$ The courts and enforcement agencies were generally following the mainstream economics of the day. ${ }^{148}$ Beginning in the $1980 \mathrm{~s}$ the

\footnotetext{
144 See Hovenkamp, supra note 38, at 25.

145 See Herbert Hovenkamp, The Antitrust Movement and the Rise of Industrial Organization, 68 TEX. L. REV. 105, 167 (1989).

146 See HOVENKAMP, supra note 4, at 206-19.

147 The most important contemporary critique was BoRK, supra note 44, at 210-16. For a more compact critique, see BOHANNAN \& HOVENKAMP, supra note 3, at 33-59.

148 See HovENKAMP, supra note 4, at 206-19.
} 
courts became much more explicit about their use of economic research in antitrust analysis.

Patent law is a remarkably different enterprise, in which the courts receive little guidance from the economic literature. A principle reason for this is that we have historically treated patents as "property" rights rather than as an element of economic policy. A distinctive feature of property rights in our legal system is that their absoluteness provides a certain degree of immunity from policies about economic development. Taken too far, the idea of patents as property can place patents on a collision course with policies about economic growth. This is why it is so critical that suitable restraints be placed on the process of patent issuance. The property right guaranteed by a patent does not kick in until the patent has been granted. But pre-issuance practice is also the place that the patent system is woefully inadequate, because precious little economic analysis goes into the development of the rules for deciding when a patent should be issued. In any event, a patent grants whatever property right the Patent Act says it grants, and need not grant anything more. In addition, while people have a "property" right in their patents, that need not include rights to do things that the Patent Act does not authorize, such as fix product prices, tie in the presence of market power, enter into exclusive contracts in the product market, or obtain injunctions outside the limits of ordinary equitable principles.

\section{Economics and Statutory Language}

Another reason for the differences between patent and antitrust approaches to economic development is statutory. In the antitrust laws the highly general "restraint of trade" and "monopolize" language of the Sherman Act, as well as the "may substantially lessen competition" language of the Clayton Act, explicitly invites courts to consider the market impact of various practices. Over time the courts have developed a wide array of tools for doing this. Nothing in the Patent Act invites either patent examiners or the courts to do anything similar. The statute itself says virtually nothing about market impact or "innovation policy." As a result, the only place market analysis plays much of a role in litigation about patents is in competition policy analysis of post-issuance practices, such as tying, pooling, price fixing and cross-licensing, mergers, exclusion, and the like. To say this more bluntly, the only time patent law pays much attention to markets is when the law incorporates antitrust principles.

Consider patent law's requirement of nonobvious subject matter. ${ }^{149}$ Its purpose is relatively uncontroversial and completely driven by our ideas about the relationship between innovation, exclusion, and economic growth: we do not want to give exclusive rights over things that someone of ordinary skill

14935 U.S.C. § 103 (2012); see KSR Int'l Co. v. Teleflex, Inc., 550 U.S. 398, 406 (2007); Graham v. John Deere Co., 383 U.S. 1, 14-17 (1966). 
could be expected to come up with independently. We should not permit people to commandeer technologies that in the ordinary course would be produced competitively rather than not at all. Having a strict nonobviousness requirement is particularly important in a regime of absolute liability for patent infringement such as we have-that is, where people can be held liable even if they did not know the technology they developed was patented by someone else. ${ }^{150}$ One of the reasons copyright and trade secret law have much lower standards of inventiveness is someone can infringe only by copying.

Empirically, there are useful ways to think about this problem. For example, if a large number of people who end up being infringers actually discovered or developed the technology entirely on their own, then the patent doctrine of nonobvious subject matter is not doing its job. In fact, the number of infringement suits that either allege willful infringement (fewer than 11\%) or prove it (fewer than $2 \%$ ) is extremely low. ${ }^{151}$ These numbers are quite telling, given that infringement plaintiffs can obtain up to treble damages by showing that patent infringement was willful. ${ }^{152}$ There could be important qualifiers, however. For example, perhaps determining how infringers came upon the infringing technology is difficult. ${ }^{153}$ That makes this particular query interesting, but hardly superfluous.

The courts have not indicated that an empirical inquiry into the extent of independent discovery is even relevant to the issue of nonobvious subject matter, either as a general matter or in specific infringement cases. In sum, we do not possess a "political economy" of nonobvious technology in the way that, say, merger law today requires economic modeling and evidence to predict the likely output or price effects of a merger. In this area the empirical science of the patent system is far behind the empirical science of industrial organization. ${ }^{154}$

By and large legal queries into nonobviousness proceed by examining existing boundaries, asking questions such as how the technology under consideration differs from earlier technology, whether something in the prior art anticipated the solution that the patent proposes, whether the prior art teaches away from the proposed solution, whether ex post conclusions of obviousness reflect hindsight bias, and the like. Most of this analysis has little

150 See infra notes 156-57 and accompanying text.

${ }^{151}$ See Christopher A. Cotropia \& Mark A. Lemley, Copying in Patent Law, 87 N.C. L. REV. 1421, 1453-54 (2009).

15235 U.S.C. $\$ 284$ (2012).

153 On this point, see Robert P. Merges, A Few Kind Words for Absolute Infringement Liability in Patent Law 5 (July 10, 2014) (unpublished manuscript), available at http://papers.ssrn.com/sol3/papers.cfm?abstract_id=2464756, archived at http://perma.cc /2P3V-VQZU.

${ }^{154}$ On the antitrust experience with economics since early in the twentieth century, see HERBERT HOVENKAMP, ENTERPRISE AND AMERICAN LAW, 1836-1937, at 241-330 (1991); Herbert Hovenkamp, United States Competition Policy in Crisis: 1890-1955, 94 MINN. L. REV. 311, 367 (2009). 
to do with human cognitive ability and invites the complaint that far too many obvious patents are granted. ${ }^{155}$ It also completely ignores the question of how patents perform as innovation facilitators in specific markets.

Given the large number of patents that are issued, we cannot afford to do much individual market impact analysis at the time of application, such as the antitrust enforcement agencies perform for reported mergers. Of course, if such analyses were performed it is very likely many fewer patents would issue. More importantly, however, we do not even do such analysis in infringement litigation, where validity is often contested on grounds of nonobviousness. Only $1.5 \%$ of patents are ever litigated, and only .1\% make it to trial. ${ }^{156}$ Further, litigating a patent infringement case commits far greater resources in most cases than obtaining one. Because the vast majority of these cases are brought against apparently unknowing infringers, the case for absolute liability depends crucially on a high degree of certainty that patents are not being granted for things that in the ordinary course would have been developed competitively. Finally, more empirically driven approaches to litigation would invite development of a research database that would affect patent issuance practices as well.

Both private and public antitrust enforcement has drawn significant resources into the economic analysis of challenged practices. Antitrust litigation and counseling create a market for economic experts, and this in turn creates a significant market for the economic study of competition-affecting practices. ${ }^{157}$ As a result, litigating an antitrust case under the rule of reason today invariably requires expert economic analysis of the effects of a challenged practice on competition, including market definition, ease of entry, probability of collusion, and the like. Patent law has very little equivalent to this forensic economic evaluation outside of damages measurement, which does use market-based tools. The typical patent infringement case reveals very little awareness that the participants are engaged in making economic policy, particularly when they make decisions about the proper scope of patents and their significance over the prior art.

155 See Gregory N. Mandel, Patently Non-Obvious: Empirical Demonstration that the Hindsight Bias Renders Patent Decisions Irrational, 67 OHIO ST. L.J. 1391, 1452 (2006); Shawn P. Miller, Where's the Innovation: An Analysis of the Quantity and Qualities of Anticipated and Obvious Patents, 18 VA. J.L. \& TECH. 1, 12 (2013); Colleen M. Seifert, Now Why Didn't I Think of That? The Cognitive Processes That Create the Obvious, 12 LEWIS \& CLARK L. REV. 489, 490 (2008).

${ }^{156}$ Mark A. Lemley \& Carl Shapiro, Probabilistic Patents, 19 J. ECON. PERSP. 75, 75 (2005).

${ }^{157}$ For example, the Antitrust Law treatise includes a large portion of a volume on the use of economic experts in antitrust litigation. See 2A PHILliP E. ArEEDA ET AL., ANTITRUST LAW ๆף 390-399 (4th ed. 2014). 


\section{Innovation, Competition, and Market Diversity}

Another critical area of difference between the antitrust and patent systems is in their recognition of variation among markets. Antitrust is acutely sensitive to issues of market structure and diversity. In many markets monopolization is regarded as structurally impossible because the number of rivals is large and entry is easy. ${ }^{158}$ Both monopolization and merger law regard market structure and diversity as critical. ${ }^{159}$ This is also true of the law of horizontal restraints under the rule of reason. We distinguish networked industries or industries with economies of scale or informational needs that justify competitor collaboration from those that do not. We also distinguish product-differentiated markets from markets for fungible products, as well as industries with high fixed costs and a heavy upfront investment component. ${ }^{160}$ Further, these differences clearly impact not only traditional price and output competition but also innovation.

Imagine an antitrust system for assessing mergers or a monopolistic practice such as exclusionary pricing that did not differentiate based on the number of firms in a market, ratios of fixed to variable costs, barriers to entry, flow of information, and the like. ${ }^{161}$ But that is very largely the legal patent system we have today, and it is increasingly clear that the operation and innovation value of patents is just as dependent on individual market characteristics as antitrust rules are. ${ }^{162}$ Patent policy is played out in a onesize-fits-all system that is largely indifferent to industry structure, nature of information dissemination, or other factors that explain when patents are socially valuable and when they are not. Its broad protections are most justified in the chemical and pharmaceutical industries for patents on primary molecules, but they are very likely not justified in high turnover technologies such as electronics, computers, communications devices, software, and business methods. Nevertheless, the law of patents has virtually no marketspecific metering.

For example, the literature on the extent of copying by claimed patent infringement defendants shows significant differences among industries. A relatively high percentage of patent infringement cases in chemical and pharmaceutical markets allege and show copying, while very few do in the information technologies. ${ }^{163}$ The data suggest alternative explanations, all of

158 See 2B AREEDA \& HOVENKAMP, supra note 135, ๆ甲 420-423, 501-507.

${ }^{159}$ See 3B id. 9ף 801-803 (discussing monopolization); 4 AREEDA \& HovenKAMP, supra note 9, 19 911-915 (discussing mergers).

$16013 \mathrm{id}$. chs. $21-22$.

161 On how the courts have required this analysis in predatory pricing cases, see $3 \mathrm{~A}$ AREEDA \& HovENKAMP, supra note 135, 1 ๆ 725-730.

162 See, e.g., John R. Allison et al., Our Divided Patent System, 82 U. CHI. L. REv. (forthcoming 2015), available at http://papers.ssrn.com/sol3/papers.cfm?abstract_id $=2510004$, archived at $\mathrm{http}: / /$ perma.cc/N5AU-38BB.

163 See Cotropia \& Lemley, supra note 151, at 1445. 
which are under researched. Perhaps the nonobviousness requirement as currently articulated works better for chemicals than for, say, communications technology. That is particularly likely to be true of patents on molecules, which could be unknowingly duplicated only by extraordinary coincidence. Or relatedly, evaluating prior art is easier for chemicals then it is for, say, electronics. Alternatively, perhaps information about patents is disseminated more effectively in the chemical and pharmaceutical industries than in other industries. Dissemination consists of two things: being able to locate a patent and being able to interpret it. The data also suggest an important question: is it merely a coincidence that the patent system seems to be functioning much better in industries such as chemicals and pharmaceuticals where the percentage of infringement claims based on copying is high? An antitrust economist looking at these data would see obvious needs for differential treatment. The current law of nonobvious subject matter seems to work better in some industries than in others.

\section{E. Asymmetric Appellate Process}

Under our current system all cases that arise under the Patent Act are appealed to the United States Court of Appeals for the Federal Circuit. Antitrust cases, like most others, go to the relevant regional circuit. Both, of course, are subject to Supreme Court review, which is rare and selective. This structure tends to insulate patent law from competition policy except in the relatively few cases that arise under the Patent Act and which also include an antitrust claim, such as a counterclaim. If the controls to economic growth have two switches, competition and innovation, the Federal Circuit very largely has control over one switch - a phenomenon that the Trebro decision, discussed above, illustrates. By contrast, the Supreme Court and (historically) the regional circuit courts had control over both. I believe this is at least a partial explanation for the divergence that has emerged between the Federal Circuit and the Supreme Court. A well-designed system should have the same courts monitoring competition policy and innovation policy, bolstered by inter-circuit competition.

\section{ECONOMIC ANALYSIS OF PATENT LAW PERFoRMANCE}

The idea that too many patents lack significant value is hardly new. Supreme Court Justice David Brewer suggested it already in the late nineteenth century, concluding that the system had far too many patents, many of which were worthless. ${ }^{164}$ Further, patent litigation had become unreasonably expensive and uncertain. ${ }^{165}$

${ }^{164}$ David J. Brewer, The Patent System, 3 YALE L.J. 149, 151 (1894). Brewer was a justice on the Supreme Court from 1889 to 1910 . His opinion of patents was all the more 
In general, the problem of patent value is beclouded by poor information. In fact, lack of market specific information about the performance of the patent system produces an unacceptably wide range of opinions about the system's value and how it can be improved. In addition, we lack good empirical information about the welfare effects of individual patent rules. Neither Congress nor the Supreme Court has insisted on the development of tools that enable decision makers to determine empirically how specific patent doctrines serve as inducements or in some cases impediments toward innovation. To a very significant extent patent drafters, lawyers, and judges interpret questions of patent validity and scope in the same way that real property lawyers have traditionally determined boundary lines in real property cases - mainly by reference to a set of rules of long standing, but rarely confronting fundamental issues of economic policy directly.

To be sure, economic assessments of industry performance are difficult to make. Views change over time, and generalist judges and lawyers may make erroneous decisions. These are good reasons for trying to do better, but not for jettisoning economic analysis from the law. Patent law will never be able to optimize innovation until it begins to internalize a "political economy" of the patent system, including the development of empirically supported conclusions about how patent law affects innovation.

Economic research on innovation and the patent system can be divided into several parts, with overlapping boundaries. These include:

1. The relative contributions to economic growth of innovation as opposed to competition under constant technology;

2. The relationship between market structure and the rate of innovation;

3. The competitive impact of post-issuance patent practices;

4. The influence of patent issuance or strength on the rate of innovation, its direction, or its quality;

5. The way that specific patent doctrines perform in the market;

6. Private patent value under the existing system; and

7. The social cost of restraints on innovation.

The following discussion examines these very briefly.

\section{A. Innovation and Economic Growth}

The literature on the relationship between innovation and economic growth is significant and has been developing since the 1940s. Joseph Schumpeter argued in Capitalism, Socialism, and Democracy that innovation

important because he was a conservative, one of the early architects of economic substantive due process.

165 See, e.g., Budd v. New York, 143 U.S. 517, 551 (1892) (Brewer, J., dissenting) (dissenting from a decision upholding price regulation of grain elevators). 
contributed much more to economic growth than competition did. ${ }^{166}$ The concern of this literature is with the relationship between innovation and growth, not with the patent system. In the 1950s Robert M. Solow's empirical work modeling economic growth with and without innovation concluded that as much as $85 \%$ of nonfarm economic growth in the twentieth century up to his time came from innovation. ${ }^{167}$ Since that time the modeling has become more complex, and has divided into different theories of growth depending on whether the relevant stimulants are endogenous or exogenous. ${ }^{168}$ But there is very little dispute over the basic proposition that innovation is the dominant contributor to growth. ${ }^{169}$

\section{B. Innovation and Market Structure}

A second body of empirical as well as theoretical literature deals with the relationship between market structure and innovation. Schumpeter believed that monopoly was essential to robust innovation because only the monopolist would have both the appropriation incentives and the economic surplus to profit from it. ${ }^{170}$ Writing roughly a decade later and after Schumpeter's death, Kenneth Arrow disagreed, pointing out that competitors have much more to lose from not innovating: if they do not innovate, someone else will. In addition, under competition firms would compete on innovation itself. Finally, one obstacle to invention by the monopolist is that innovation would tend to displace its own established technology. By contrast, competitors must continuously worry that if they do not develop new technology someone else will. As for appropriation incentives, Arrow believed the patent system would take care of them. ${ }^{171}$

This Schumpeter-Arrow "debate" spawned an enormous body of literature in industrial organization economics, both theoretical and empirical. The emergent consensus is that neither Schumpeter nor Arrow had it exactly right, although Arrow was somewhat closer. The innovation/market structure curve

166 JoSEPH A. SCHUMPETER, CAPITALISM, SOCIALISM AND DEMOCRACY 81-86 (1942).

${ }^{167}$ Robert M. Solow, Technical Change and the Aggregate Production Function, 39 REV. ECON. \& STAT. 312, 316 (1957); see also BOHANNAN \& HovENKAMP, supra note 3, at 295-98; ElHANAN Helpman, THE Mystery of ECONOMiC GrowTH 7, 34-35 (2004).

168 See generally Philippe Aghion \& Peter Howitt, Endogenous Growth Theory (1998); Gene M. Grossman \& Elhanan Helpman, Endogenous Innovation in the Theory of Growth, 8 J. ECON. PERSP. 23 (1994).

${ }^{169}$ See the strong assumptions about the relationship made in THOMAS PIKETTY, CAPITAL IN THE TWENTY-FIRST CENTURY 72-109 (Arthur Goldhammer trans., Belknap Press of Harvard Univ. Press 2014) (2013).

${ }^{170}$ SCHUMPETER, supra note 166, at 81-86.

${ }^{171}$ Kenneth J. Arrow, Economic Welfare and the Allocation of Resources for Invention, in ESSAYS IN THE THEORY OF RISK-BEARING 144, 156-60 (Kenneth J. Arrow ed., 1971). 
is in fact an inverted "U." 172 Monopolized markets tend not to exhibit a great deal of innovation, but neither do highly competitive markets. Rather, innovation proceeds most quickly in moderately concentrated, productdifferentiated markets that have relatively large firms but also sufficient competition that each firm offers an innovation threat to the others.

\section{Economic Effects of Patent Practices}

A large body of literature, stretching back nearly a century, concerns the economic impact of various uses of patents that have already been issued. ${ }^{173} \mathrm{~A}$ related and also extensive law review literature looks more specifically at antitrust rules, but frequently invokes the economics literature. ${ }^{174}$ The

172 See John T. Scott \& Troy J. Scott, Innovation Rivalry: Theory and Empirics, $41 \mathrm{~J}$. Indus. \& Bus. ECON. 25, 25 (2014); see also Philippe Aghion et al., Competition and Innovation: An Inverted-U Relationship, 120 Q.J. ECON. 701, 701-28 (2005); Koki Arai, Patents, Competition Policy, and Growth, 18 J. TECH. L. \& POL'Y 83, 84 (2013). The literature is summarized in BOHANNAN \& HOVENKAMP, supra note 3, at 9-11.

173 In chronological order and emphasizing historical work, see J. MAURICE CLARK, STUdies IN THE ECONOMICS OF OVERHEAD COSTS (1923); FlOYd L. VAUGHAN, ECONOMICS of Our Patent System (1925); Arthur Robert Burns, The Decline of Competition 11-17 (1936); Thurman W. ARnold, The BottleneCKS of Business (1940); Walton Hamilton, Patents And Free Enterprise (1941); LAWrence I. WoOd, PATENTS AND ANTITRUst LAW (1942); OtTO RAYMOND BARNETT, PATENT PROPERTY AND THE ANTIMONOPOLY LAWS (1943); GEORGE W. STOCKING \& MYRON W. WATKINS, MONOPOLY AND FreE ENTERPRise (1951); Gustav DreWs, The PATENT Right IN THE NATIONAL ECONOMY OF THE UNITED STATES (1952); BOWMAN, JR., supra note 24 at 239; see also, in chronological order, Floyd L. Vaughan, The Relation of Patents to Industrial Monopolies, 147 Annals Am. ACAD. Pol. \& Soc. ScI. 40 (1930); Alfred E. Kahn, Fundamental Deficiencies of the American Patent Law, 30 AM. ECON. REV. 475, 483-84 (1940); Michael Polanvyi, Patent Reform, 11 ReV. ECON. STuD. 61 (1944); Bowman, Jr., supra note 23, at 19; Statement of Grounds for Action, United States v. Hartford-Empire Co., 46 F. Supp. 541 (S.D. Ohio 1942) (No. 4426). For more discussion of the literature prior to passage of the 1952 Patent Act, see HovENKAMP, supra note 4, at 184-91 (discussing patents and then antitrust).

${ }^{174}$ See generally Rome G. Brown, The Right to Refuse to Sell, 25 YALE L.J. 194 (1916); Mortimer Feuer, Patent Abuse Versus National Interest, 2 LAW. GuILD REV. 1 (1942); Walton Hamilton, Property Rights in the Market, 1 J. LeGAL \& POL. Soc. 10 (1943); Horace R. Lamb, The Relation of the Patent Laws to the Federal Anti-trust Laws, 12 CoRnell L.Q. 261 (1927); Philip Marcus, Patents, Antitrust Law and Antitrust Judgments Through Hartford-Empire, 34 GEO. L.J. 1, 36-51 (1945); F. Granville Munson, Control of Patented and Copyrighted Articles After Sale, 26 YALE L.J. 270 (1917); David L. Podell \& Benjamin S. Kirsh, Patent Pools and the Anti-trust Laws, 13 A.B.A. J. 430 (1927); Irving I. Schachtel, Patent Pools and the Federal Anti-trust Laws, 5 LINCOLN L. REV. 7 (1932); George H. Schueller, The New Antitrust Illegality Per Se: Forestalling and Patent Misuse, 50 Colum. L. REv. 170, 172 (1950); Roscoe Steffen, Invalid Patents and Price Control, 56 Yale L.J. 1 (1946); H.A. Toulmin, The Patent Law and the Sherman Law, 1 VA. L. REV. 445 (1914); Comment, The Effect of Nonuse on a Patentee's Remedy Against Infringement, 18 YALE L.J. 52, 53 (1908) (discussing the Paper Bag decision); Note, Patent Abuses and Antitrust: The Per Se Rule, 64 HarV. L. REV. 626 (1951); Note, 
theoretical and empirical literature ranges over such subjects as the economic effects of tying, pooling, price fixing, price discrimination, the impact of patents on product differentiation and the resulting competition among firms, the use of patents by dominant firms, and the like. While this literature concerns the use of issued patents, nearly all of it properly falls into the domain of competition policy rather than analysis of the patent system. In most of it the internal workings of the patent system are not even discussed. ${ }^{175}$

\section{Patents, Economic Growth, and the Direction of Innovation}

A fourth issue concerns the relationship between patent issuance or patent strength and economic growth, and relatedly, the relationship between the availability of patents and the direction of innovation. ${ }^{176}$ As patent protection is greater, measured by either duration or breadth, the incentive to obtain patents increases but the dissemination of knowledge decreases. Economic growth depends both on sufficient incentives to innovate plus the effective dissemination of innovation through the economy. Finding the right balance presents an empirical question.

The more general literature on patent issuance and economic growth is inconclusive, with most of it suggesting little correlation between a country's patent system and its rate of economic growth. ${ }^{177}$ More discriminating studies

Patent Dedication as Antitrust Remedy: New Light on Hartford-Empire, 63 YALE L.J. 717 (1954). For a good, brief economic analysis of the competitive effects of post-issuance patent practices, see LANDES \& POSNER, supra note 32, at 372-402.

${ }^{175}$ For a good summary of the literature prior to its publication date, see Jonathan B. Baker \& Daniel L. Rubinfeld, Empirical Methods in Antitrust Litigation: Review and Critique, 1 AM. L. \& ECON. REV. 386, 386-91 (1999).

176 On this second point, both Arthur Cecil Pigou and Arnold Plant argued that the availability of patents would channel innovation toward patentable areas because appropriability would be greater. See Arthur C. Pigou, The ECONOMICs OF Welfare 185 (4th ed. 1932); Arnold Plant, The Economic Theory Concerning Patents for Inventions, 1 ECONOMICA 30, 30-32 (1934). The point is developed further in Baxter, supra note 24. One can say much the same things about trade secrets or copyrights.

${ }^{177}$ David M. Gould \& William C. Gruben, The Role of Intellectual Property Rights in Economic Growth, 48 J. DEV. ECON. 323, 328-38 (1996); Walter G. Park \& Juan Carlos Ginarte, Intellectual Property Rights and Economic Growth, 15 CONTEMP. ECON. POL'Y 51, 54-56 (1997). A recent study found a correlation between the existence of a patent system and total factor production (TFP) growth, but also concludes that there is an inverse correlation between the strength of patent rights and TFP growth. See Xin Chang et al., Patents and Productivity Growth: Evidence from Global Patent Awards 26 (Feb. 20, 2013) (unpublished manuscript), available at http://papers.ssrn.com/sol3/papers.cfm?abstract_id $=2371600$, archived at http://perma.cc/79MT-ZU3X (While patent rights lead to more patents, "our findings also suggest that patent rights slow the diffusion of new innovations throughout the economy, as we find that the effect of patents on TFP growth is weaker in countries with stronger patent rights. Our results suggest that finding the optimum level of patent protections requires the consideration of these two offsetting effects."); see also Rod Falvey et al., Intellectual Property Rights and Economic Growth, 10 REV. DEV. ECON. 700, 
that break industries into different groupings find positive correlations in markets where products are durable, investment costs are high, but copying is cheap, such as chemicals and pharmaceuticals. ${ }^{178}$ By contrast, studies of information technologies and software often find just the opposite: the patent system actually tends to hinder economic development. ${ }^{179}$ Some studies also find that the effect of patent protection in restricting the dissemination of knowledge outweighs its effect in inducing innovation, thus producing a negative correlation between patenting and economic growth. ${ }^{180}$

None of this literature is absolutely conclusive and it has not come close to establishing a consensus on these issues. One startling likelihood, however, is that while innovation contributes a great deal to economic growth, the patent system may not contribute much to innovation, although the results vary from one market to another.

This literature must also be qualified by another important factor, which is the cost of the patent system itself. Obtaining patents is costly and litigating them is even more costly. Further, the patent system creates risks for innovators and, as a result, costly duties to search. One very troubling conclusion for many markets is that there is not any "tradeoff" at all between the value of appropriation and the hindrance to dissemination. In fact, the appropriation value is negative because even looking at purely private costs and returns, the patent system costs innovators more than it is worth. ${ }^{181}$ Once again, chemicals and pharmaceuticals are an outlier on the positive side. ${ }^{182}$

700-01 (2006) (noting that at least in middle income countries, intellectual property rights cause more harm by restricting the dissemination of technology than they contribute to economic growth).

${ }^{178}$ For a summary of this literature, see Michael Meurer \& James Bessen, Do Patents Promote Economic Growth?, TeCh. InNOvation \& Intell. Prop. (Mar. 17, 2008), $\mathrm{http}: / /$ www.researchoninnovation.org/WordPress/?p=95, archived at http://perma.cc/TW C5-38VL (finding pharmaceuticals to be an outlier in a large number of diverse studies); see also Albert G.Z. Hu \& I.P.L. Png, Patent Rights and Economic Growth: Evidence from Cross-Country Panels of Manufacturing Industries 2, 4 (Aug. 2012) (unpublished manuscript), available at http://papers.ssrn.com/sol3/papers.cfm?abstract_id=1339730, archived at http://perma.cc/MTE5-VWEB; Yi Qian, Do National Patent Laws Stimulate Domestic Innovation in a Global Patenting Environment? A Cross-Country Analysis of Pharmaceutical Patent Protection, 1978-2002, 89 REV. ECON. \& STAT. 436, 450 (2007) (making dubious conclusions even about chemical and pharmaceutical patents).

${ }^{179}$ See, e.g., Julie E. Cohen \& Mark A. Lemley, Patent Scope and Innovation in the Software Industry, 89 CALIF. L. REV. 1, 56-57 (2001).

180 See Lee G. Branstetter, Do Stronger Patents Induce More Local Innovation?, 7 J. INT'L. ECON. L. 359, 369-70 (2004); see also Andrew W. Torrance \& Bill Tomlinson, Patents and the Regress of Useful Arts, 10 ColuM. SCI. \& TECH. L. REV. 130, 132-35 (2009) (using simulation to come to similar conclusions).

181 See BESSEN \& MEURER, supra note 86, at 120-46.

182 See id. at 95-120. 


\section{E. The Economic Performance of Specific Patent Doctrines}

An economically defensible patent system requires patent rules that can enable its goals. How do rules concerning such issues as patent duration, the requirement of nonobvious subject matter, enablement, or the doctrine of equivalents perform in the market? There is very little empirical study of how individual patent doctrines perform, although a significant "meta" empirical literature exists on judicial behavior concerning these doctrines. ${ }^{183}$ By contrast, antitrust law often adopts specific doctrines by linking them to market performance or expectations. One example is antitrust law's per se rule, which is applied only after judicial experience indicates that certain practices as a class are highly likely to reduce market wide output and increase price. ${ }^{184}$ Another example is the "recoupment" requirement in predatory pricing law, which uses economic analysis and empirical study to link the law of predatory pricing to rational expectations about monopoly outcomes in specific markets. ${ }^{185}$

Antitrust rules evaluate practices by asking market performance questions, often in the context of litigation, although also by relying on industry studies that are later used in litigation. For example, as a matter of doctrine, monopolization and merger law require definition of a "relevant market" in which the threat of monopoly or cartel behavior can be assessed. Relevant market queries are highly empirical and market specific, looking at such factors as degree and speed of substitution from inside to outside, the number of firms in the market and their size, and the history of new entry. For antitrust purposes, markets differ so much from one another that each new market requires its own inquiry. Doing that is costly but it is based on recognition that the thing we are attempting to measure is very specific to the environment in which it occurs.

183 See, e.g., Jason Rantanen, The Federal Circuit's New Obviousness Jurisprudence: An Empirical Study, 16 StAn. TeCH. L. REV. 709, 732-61 (2013); see also Ali Mojibi, An Empirical Study of the Effect of KSR v. Teleflex on the Federal Circuit's Patent Validity Jurisprudence, 20 ALB. L.J. SCI. \& TECH. 559, 581-96 (2010). For pre-KSR literature, see Christopher A. Cotropia, Nonobviousness and the Federal Circuit: An Empirical Analysis of Recent Case Law, 82 Notre DAME L. REV. 911, 912-15 (2007); see also J. Jonas Anderson \& Peter S. Menell, Informal Deference: A Historical, Empirical, and Normative Analysis of Patent Claim Construction, 108 Nw. U. L. REV. 1, 63-76 (2014) (discussing claim construction and scope); Dennis Crouch, An Empirical Study of the Role of the Written Description Requirement in Patent Examination, 104 Nw. U. L. REV. 1665, 166568 (2010) (discussing written description); Christopher B. Seaman, Willful Patent Infringement and Enhanced Damages After In re Seagate: An Empirical Study, 97 IowA L. REV. 417, 439-51 (2012) (discussing willful infringement).

184 See 7 AREEDA \& HoVENKAMP, supra note 9, ๆ 1509; 11 id. $\mid 1909 \mathrm{~b}$ (addressing horizontal restraints).

185 See Brooke Grp. Ltd. v. Brown \& Williamson Tobacco Corp., 509 U.S. 209, 224 26 (1993) (developing the recoupment requirement); see also 3A AREEDA \& HOVENKAMP, supra note $135,99725-727$. 
The work that has been done on various patent doctrines suggests exactly the same thing - namely, that a one-size-fits-all approach is completely wrong headed. That is clearly true of patent duration. ${ }^{186}$ A longer patent term increases the incentive to patent, although by less than one might think. ${ }^{187}$ As William Landes and Richard Posner note, at a discount rate of $10 \%$, which is probably low for patented goods with high price/cost margins, the ex ante value of a twenty-year patent is approximately $85 \%$ of a patent whose duration is infinite. ${ }^{188}$ Once they calculate what they believe to be a realistic depreciation rate, the number is closer to $95 \% .{ }^{189}$ Just as a lease or any other property right with a limited term, a patent depreciates in value as it gets closer to expiration. A patent also depreciates in value to the extent that the demand for the product it covers declines, perhaps because it has become obsolete, or perhaps because more and closer substitutes become available as the technology matures. For example, if others develop alternatives to the patented technology over the patent's lifetime the market for that patent will become increasingly competitive, and its value accordingly less. At the same time, the harm caused by exclusion extends over the full term. These numbers are frankly not very revealing about the impact of longer terms on the balance between incentive and dissemination of information, except to suggest that shorter terms give us somewhat smaller incentives, significantly reduced exclusionary effects, and thus more rapid dissemination of technology. Indeed, in some information technology areas considerable technology may become obsolete in the market before the patents on them expire. This makes the Constitution's "limited times" prescription meaningless and indicates that the patent system is not facilitating the dissemination of this technology at all.

Overall, the existing literature provides very little insight into the effects of either specific patent or antitrust rules on economic performance. For example, there is little to no empirical support for suggestions made by some that limiting pay-for-delay pharmaceutical settlements reduces welfare in the pharmaceutical industry. ${ }^{190}$ To be sure, any practice that tends to increase the duration of patent protection increases the incentive to patent, ${ }^{191}$ but ex ante

186 See, e.g., Eric E. Johnson, Calibrating Patent Lifetimes, 22 SANTA ClarA COMPUTER \& High TECH. L.J. 269, 308-09 (2006).

${ }^{187}$ See, e.g., Mark A. Lemley, An Empirical Study of the Twenty-Year Patent Term, 22 AIPLA Q.J. 369, 392-93 (1994) (finding a greater incentive to innovate in most industries as term went to twenty years from date of application).

188 LANDES \& POSNER, supra note 32, at 296.

${ }^{189}$ Id.

${ }^{190}$ Among those making this suggestion are Henry N. Butler \& Jeffrey Paul Jarosch, Policy Reversal on Reverse Payments: Why Courts Should Not Follow the New DOJ Position on Reverse-Payment Settlements of Pharmaceutical Patent Litigation, 96 IowA L. REV. 57, 90-91 (2010); James Langenfeld \& Wenqing Li, Intellectual Property and Agreements to Settle Patent Disputes: The Case of Settlement Agreements with Payments from Branded to Generic Drug Manufacturers, 70 ANTITRUST L.J. 777, 809-10 (2003).

${ }^{191}$ See, e.g., David S. Abrams, Did TRIPS Spur Innovation? An Analysis of Patent Duration and Incentives to Innovate, 157 U. PA. L. REV. 1613, 1641-42 (2009). 
the incentive is not all that large, as the Landes and Posner conclusions indicate. ${ }^{192}$ Further, that number needs to be offset by dissemination effects. Even incentive effects are uncertain. A likely impact of restricting pay-fordelay settlements is to increase patentee incentive to develop new drugs that start the patent clock over, as an alternative to weak extensions of patents on old drugs. ${ }^{193}$ Further, one must consider the generally low quality of the extension patents that are subject to pay-for-delay settlements. ${ }^{194}$ Given the exclusive rights they create, the incentive to obtain them may be strong, but if they provide protection over developments that in the ordinary course would have been provided competitively, their social value is negative.

Returning to the question of nonobvious subject matter, a court reviewing a performance based litigation question might consider how many independent inventors had developed the same technology. For example, in the Alexsam, Inc. v. IDT Corp litigation the defendant had sued thirteen different "stored value" gift card manufacturers for infringing its patent. ${ }^{195}$ That fact alone should have provoked a query into such questions as how many relevant gift card manufacturers there are, and whether they had copied this technology or developed it independently. If the requirement of nonobvious subject matter is performing as it should, we should not have a large number of independent developers. The Federal Circuit found that the defendant had not established obviousness by looking at some prior art, particularly since it failed to provide expert testimony on the question of whether a skilled artisan would have been independently motivated to combine the various prior art references. ${ }^{196} \mathrm{In}$ short, the court asked a backward looking "boundaries" question when it should have been asking an "economic performance" question.

Without changing the doctrine of absolute liability, a court interested in a performance-based rule of nonobvious subject matter might develop a presumption that if, say, $10 \%$ of the producers in a market are infringing, then

\footnotetext{
192 See LANDES \& POSNER, supra note 32, at 422.

193 See Francesca Cornelli \& Mark Schankerman, Patent Renewals and R\&D Incentives, 30 RAND J. ECON. 197, 197-98 (1999).

194 See infra notes 247-50 and accompanying text.

195 Sua Sponte Order of Severance 1, Alexsam, Inc. v. Best Buy Co., No. 2:10cv93 (E.D. Tex. Jan. 3, 2013) (involving the Alexsam litigation); see also Unified Messaging Solutions, LLC v. United Online, Inc., No. 13C00343, 2013 WL 1874211, at *1 (N.D. Ill. May 3, 2013); EIT Holdings LLC v. Yelp!, Inc., No. C10-05623, 2011 WL 2192820, at *2 (N.D. Cal. May 12, 2011). The America Invents Act added a provision that limits the ability of an infringement plaintiff to join a large number of defendants who are acting independently into a single cause. 35 U.S.C. § 299(a) (2012); see also In re EMC Corp., 677 F.3d 1351, 1353, 1355-56 (Fed. Cir. 2012) (noting that joinder provision is not retroactive and considering pre-passage complaint naming eighteen infringement defendants in a single suit). Of course, a patentee can still bring separate suits against a large number of claimed infringers. See Intellectual Ventures I, LLC v. Capital One Fin. Corp., No. 1:13-CV-00740, 2013 WL 6682981, at*5 (E.D. Va. Dec. 18, 2013) (alleging such a scheme).

196 Alexsam, Inc. v. IDT Corp., 715 F.3d 1336, 1347-48 (Fed. Cir. 2013).
} 
the subject of the patent must be obvious. The infringement plaintiff could defeat the presumption by showing that the infringers are in fact copyists or that the product, once on the market, is easy to copy and the infringers had access to it. For example, a showing that the product is easy to copy and was widely disseminated prior to rivals' entry creates an inference of copying. By contrast, the fact that a large number of firms are infringing an electrical or business method patent held by a non-practicing entity is a strong indicator that the patent's subject matter is obvious. ${ }^{197}$ That question will be difficult to answer in close cases, but not so difficult in many others. Further, it would actually measure what the nonobvious requirement should be measuring. Most importantly, it would lead to a body of empirical work guiding these determinations in the future.

\section{F. Comparative Advantage}

Legal policy makers must make decisions with the tools and information available to them, even if they are not perfect. At this time our knowledge about the relationship between antitrust law and traditional competition, while imperfect, is much more complete than our knowledge about the relationship between patent law and innovation - and more particularly, about the impact of particular patent doctrines on innovation. In that setting it is not irrational to condemn a practice that is highly likely to decrease welfare via collusion or exclusion in the shorter run based on nothing but an unsupported hunch that it might also increase innovation.

\section{RESTRAINTS ON INNOVATION}

One important corollary to the observation that innovation contributes much more to economic growth than does competition under constant technology is that restraints on innovation can do much greater harm than restraints on simple competition. ${ }^{198}$ To an extent, the Patent Act itself or the courts interpreting it restrain innovation when exclusion effects outweigh the incentive effects. Several of the studies previously mentioned have observed that possibility. A well-known example is broad use of the patent law doctrine of equivalents to shut down technologies that are actually inventions in their own right. For example, in Wright Co. v. Herring-Curtiss Co. (Wright v. Curtiss), the Wright brothers were able to get a very broad interpretation of their patent that shut down the superior technology contained in the Curtiss airplane. ${ }^{199}$ The Wright brothers' design employed flexible fabric covered

197 See, e.g., Market-Alerts Pty., Ltd. v. Bloomberg Fin., LP, 922 F. Supp. 2d 486, 488-89 (D. Del. 2013) (involving business method patent claim by non-practicing entity filed against multiple stock trading companies).

198 See BOHANNAN \& HovenKAMP, supra note 3, at 238-57.

199 Wright Co. v. Herring-Curtiss Co., 204 F. 597 (W.D.N.Y. 1913), aff'd, 211 F. 654, 655 (2d Cir. 1914); see Merges \& Nelson, supra note 32, at 890-91. 
wings and a series of cables that twisted, or "warped," them in order to steer and level the plane. ${ }^{200}$ By contrast, Curtiss's alternative used hinged ailerons, capable of being used with rigid metal wings, and similar to the technology in current use. ${ }^{201}$ While the practical result of Wright v. Curtiss is controversial, it may have delayed the development of a military-worthy United States aircraft until after World War One was over. ${ }^{202}$ The government eventually pressured the parties to cross license. ${ }^{203}$ Another is the Supreme Court's 1908 Continental Paper Bag Co v. Eastern Paper Bag Co. decision, which once again relied on a broad interpretation of the doctrine of equivalents to shut down a dominant firm's competitor, who was in fact using a different technology than the dominant firm was using. ${ }^{204}$

Only some restraints on innovation come through the patent system itself, however. Most are the result of conduct for which the Patent Act is largely irrelevant. Examples include Microsoft's successful use of its market power to force Intel to cease development of a microchip capable of efficiently processing Java's multi-language instructions. Microsoft feared that efficient translation and processing of different computer languages would weaken the hold of its Windows operating system by making it easier for non-Windows systems to be compatible. ${ }^{205}$ Another example was a cartel among American automobile manufacturers to suppress the development of low emissions automobile technology. ${ }^{206}$ A further example was the temporarily successful efforts of Allied Tube to withhold legal approval to plastic electric conduit, a lower cost and technologically superior alternative to Allied's steel conduit. ${ }^{207}$ And yet another example was a market dominant newspaper's use of exclusivity threats to deter the advance of radio advertising, a nascent competing technology. ${ }^{208}$ To my knowledge no one has ever attempted to

200 Wright, 204 F. at $600-01$.

201 Id. at 609.

202 Merges \& Nelson, supra note 32, at 890-91.

${ }^{203}$ Mfrs. Aircraft Ass'n v. United States, 77 Ct. Cl. 481, 485 (1933) (detailing the government "suggestion" of cross-licensing).

${ }^{204}$ See Cont'l Paper Bag Co. v. E. Paper Bag Co., 210 U.S. 405, 427-30 (1908); see also infra notes 455-56 and accompanying text.

${ }^{205}$ United States v. Microsoft Corp., 84 F. Supp. 2d 9, 17-18, 28-29 (D.D.C. 1999), aff'd in part, rev'd in part, 253 F.3d 34, 73-78 (D.C. Cir. 2001). See generally ANDREW I. GAVIL \& HARRY First, THE Microsoft ANTITRUst CASES: COMPETITION POLICY FOR THE TWENTY-FIRST CENTURY (2014).

${ }^{206}$ See In re Motor Vehicle Air Pollution Control Equip., 52 F.R.D. 398, 401-02 (C.D. Cal. 1970).

${ }^{207}$ Allied Tube \& Conduit Corp. v. Indian Head, Inc., 486 U.S. 492, 496-97 (1988). But see SD3, LLC v. Black \& Decker (U.S.), Inc., No. 1:14-cv-191, slip op. at 7 (E.D. Va. July 15, 2014) (dismissing for lack of agreement complaint that defendants manipulated standard-setting process for electric saws so as to exclude plaintiff's invention that stopped a saw blade upon contact with human skin).

${ }^{208}$ Lorain Journal Co. v. United States, 342 U.S. 143, 152-53 (1951); see Spencer Weber Waller \& Matthew Sag, Promoting Innovation, 100 IowA L. REV. (forthcoming 
catalog such events completely, and certainly not to estimate their social impact, but it is almost certainly large. 209

Aside from the anti-innovation aspects of some patent rules, as discussed above, the problem of innovation restraints is best analyzed through the antitrust system. First of all, a restraint on innovation is an "output" restraint, just as much as a restriction on the number of units of a good to be produced. As a result it can readily be modeled through the ordinary tools of price theory, which typically regard it as leading to higher prices if the innovation would have reduced cost; or a shift in the demand curve if the innovation would have made a product more attractive. Some innovations, such as the plastic conduit in the Allied Tube \& Conduit Corp. v. Indian Head, Inc. decision, do both of these things at the same time.

The presence and ubiquity of restraints on innovation suggests that legal policy take them more seriously. Patent law has an important role to play here, principally in ensuring that overly broad interpretations do not serve to restrain rather than incentivize innovation. For example, a developing concern about the activities of non-practicing patent assertion entities is that they may be restraining innovation by deterring firms from innovating in the areas where Patent Assertion Entities (PAEs) have large portfolios. ${ }^{210}$ To the extent that is true, the fix will very likely have to come from patent law rather than antitrust.

\section{USING PATENT AND ANTITRUST LAW TO ASSESS INNOVATION- AFFECTING ANTICOMPETITIVE CONDUCT}

This section offers some preliminary considerations for assessing antitrust/patent conflicts. Then we turn to the most commonly occurring conduct areas, delineating the proper role of antitrust for each.

\section{A. Principles for Resolving Antitrust/Patent Conflicts}

1. Pre-issuance conduct involving patents is generally not addressable under the antitrust laws, although pre-issuance conduct may be relevant to certain forms of post-issuance exclusionary behavior, such as the filing of unreasonable infringement suits. The patent system is a largely complete and effective regulator of pre-issuance conduct, and it is not antitrust law's purpose to police other federal regulatory regimes.

2. A practice that is expressly authorized by the Patent Act cannot be the basis of an antitrust claim, provided that the conduct in

2015) (manuscript at 7), available at http://papers.ssrn.com/sol3/papers.cfm?abstract_id $=2479569$, archived at $\mathrm{http}: / /$ perma.cc/7U3T-VBS9.

${ }^{209}$ For more substantiated accounts, see BOHANNAN \& HoVENKAMP, supra note 3, at 238-57; Hovenkamp, supra note 137, at 249-52.

${ }^{210}$ See infra notes $465-75$ and accompanying text. 
question falls within the authorization. This proposition is nothing more than a general rule of statutory construction: specific statutory authorizations in a federal statute should control general prohibitions, such as those contained in the antitrust laws.

3. Post-issuance practices that are not authorized by the Patent Act should be evaluated under ordinary antitrust rules, which take both static competition effects and innovation effects into account. Saying that a practice is subject to the antitrust laws, however, is not to conclude that it violates them.

4. Active production under a patent license can indicate that a restraint is "ancillary," justifying rule of reason treatment, ${ }^{211}$ but it is important to distinguish restraints in the licensing market from restraints in the product market.

5. Innovation affecting conduct falls within the domain of antitrust just as much as patent law, with the important limitation that antitrust applies only to innovation affecting conduct that is also anticompetitive. While the patent law's own system sometimes works to restrain innovation, it is not antitrust law's place to second-guess the way that Congress, patent officials, or judges make or interpret patent law. For example, judicial recognition of an overly broad doctrine of equivalents, ${ }^{212}$ a judge-made rule, may restrain innovation, but policing the behavior of federal judges is not an antitrust function. By contrast, most post-issuance restraints on innovation are privately created and completely within antitrust law's reach.

6. The range of "agreements" covered by the antitrust laws is broader than the range of "licenses" authorized by the Patent Act. This principle is particularly important for assessing large industry-wide arrangements that include cross-licenses but may also be subject to other agreements or agreement facilitators, not all of which will be in writing.

7. A court generally need not determine patent validity or infringement in order to assess the antitrust legality of a settlement or other license agreement. For antitrust, the relevant question is the objectively measured effects of the agreement and the parties expectations about the quality of the patent(s) at the time the agreement was made. A later finding of patent invalidity should not create antitrust liability for a settlement that was reasonably deemed lawful when created; nor should a later finding of validity serve to ratify an agreement reasonably regarded as anticompetitive. This is consistent with the general principle that economics takes an ex ante rather than ex post

211 On the rule of reason, see infra notes 221-22 and accompanying text.

212 See infra notes 456 and accompanying text. 
approach to decision making. Further, requiring judicial inquiries into patent validity and infringement in order to evaluate a settlement agreement brings back in the very questions that the disputing parties were seeking to avoid at the time of their settlement. $^{213}$

\section{B. Product Restraints vs. Patent Restraints}

A simple patent license covers the use of patents, not the production of products. The difference is important for two reasons. First, many patents cover only a component of a product, and the patent may have alternatives or be amenable to inventing around. Secondly, nothing in the Patent Act authorizes market division or price fixing of products, but only the licensing of patents. As the number of patents becomes larger and their individual coverage smaller, the distinction between patent restraints and product restraints becomes all the more important. For example, under the Patent Act a maker of outdoor grills who has patented a unique igniter may license the igniter technology to a competing grill maker and specify the geographic area in which that patent can be used, perhaps limiting competition with itself in certain areas. The Patent Act expressly permits domestic geographic restrictions on a patent license. ${ }^{214}$ What the Patent Act does not authorize, however, is an agreement under which the patentee limits the territories in which the licensee can sell any outdoor grills whatsoever, whether or not they practice the patent. ${ }^{215}$ That would be a product market restraint and it is fully subject to the antitrust laws. ${ }^{216}$ The distinction is important because there may be a robust market remaining for outdoor grills that do not have the igniter in question. Indeed, the igniter may do little more than create a product differentiation that some consumers prefer but not others. Second, there may be alternative technologies that get the same job done, or it may be possible for the second firm to invent around the patent, a practice that patent law generally encourages.

Most antitrust condemnations of restrictive licensing agreements have involved restraints with a significant impact in the product market. At the same time, however, only a subset of product market restraints violate the

213 See Edlin et al., supra note 141; Hovenkamp, supra note 38 , at *10.

21435 U.S.C. $\$ 261$ (2012).

215 As a matter of patent policy, the exhaustion, or "first sale," doctrine might refuse to enforce such a restriction imposed in a patent license if the good in question was sold. See Keeler v. Standard Folding Bed Co., 157 U.S. 659, 664-67 (1895) (refusing to enforce territorial restriction imposed via patent license on good after sale); Adams v. Burke, 84 U.S. (17 Wall.) 453, 456-57 (1873) (same).

216 See, e.g., Ansul Co. v. Uniroyal, Inc., 448 F.2d 872, 880-81 (2d Cir. 1971) (holding that resale price maintenance of patented product constituted both a per se Sherman Act offense and patent misuse); Solvex Corp. v. Freeman, 459 F. Supp. 440, 442-48 (W.D. Va. 1977) (similar but with vertical territorial restraints). 
antitrust laws. For example, suppose that the patentee of the grill igniter licenses it and specifies the price at which the grills must be sold. Assuming that the patentee does not make grills itself, this would be resale price maintenance (RPM), a vertical practice that is governed by the rule of reason and most often lawful. ${ }^{217}$ Alternatively, a grill manufacturer might create a dealership network to sell the grills, giving dealers an express or implied license for patented technology, and might also impose dealer location restrictions on dealer sales of the grills themselves. But these would be vertical nonprice restraints, which are covered by the rule of reason and are usually lawful. ${ }^{218}$

One interesting aspect of pharmaceutical pay-for-delay settlements is that typically the patent and the product are coterminous, at least as a practical matter. This is because drugs falling under the Hatch-Waxman Act must be "bioequivalent" in order to qualify for abbreviated FDA testing. A generic firm invoking the statute does not typically have the option of inventing around the patent, for the resulting drug would not be bioequivalent. Pay-fordelay settlements such as the one in the Actavis case effectively create a market division in the product market, an area where antitrust scrutiny has historically been justified. ${ }^{219}$ One might object that the only way one can have a patent license restriction on a bioequivalent drug is to have product market restriction as well. The argument might carry some weight but for the fact that a pay-for-delay settlement is not a license at all for the delay period, because under it the generic firm is not authorized to produce anything during that period. As a result it cannot be characterized as a restricted production license of the kind that has generally received benign treatment under the antitrust laws. 220

\section{Modes of Antitrust Inquiry}

Courts analyze most antitrust claims under the rule of reason, which requires the plaintiff to show initially that the defendant has sufficient market power and that the challenged practice injures competition by facilitating either collusion or anticompetitive exclusion. At that time, the burden of proof

${ }^{217}$ When RPM was unlawful per se, it was frequently used to condemn RPM on the product contained in license agreements. See United States v. Univis Lens Co., 316 U.S. 241, 247-52 (1942) (bifocal lens blanks ground with a patented process); Ethyl Gasoline Corp. v. United States, 309 U.S. 436, 442-43 (1940) (gasoline containing patented additive); Cummer-Graham Co. v. Straight Side Basket Corp., 142 F.2d 646, 647 (5th Cir. 1944) (patentee of basket-making machine could not impose RPM on unpatented baskets made with the machine). Since 2007, resale price maintenance has been addressed under antitrust law's rule of reason. See Leegin Creative Leather Prods., Inc. v. PSKS, Inc., 551 U.S. 877, 907 (2007).

218 Cont'l T.V., Inc. v. GTE Sylvania Inc., 433 U.S. 36, 47-59 (1977).

${ }^{219}$ See FTC v. Actavis, 133 S. Ct. 2223, 2237-38 (2013); see also supra notes 120-30 and accompanying text.

${ }^{220}$ See supra notes $210-18$ and accompanying text. 
shifts to the defendant to provide evidence of a justification, or legitimate objective. $^{221}$ The plaintiff can counter, however, by showing that the same objective could have been reached by a less restrictive alternative. ${ }^{222}$

Within each of these elements of proof there may be additional presumptions. For example, a high market share of a properly defined relevant market creates a presumption of market power, but the presumption can be defeated by proof of easy entry. ${ }^{223}$ While computation of market share is historically the most common way of establishing power, there are others. ${ }^{224}$ The Actavis majority correctly concluded that a high pay-for-delay payment itself could create a presumption of market power, for only a firm with power would have the ability to make such a payment. ${ }^{225}$ The Supreme Court then went on to apply the rule of reason in the conventional way. Once the plaintiff had provided sufficient evidence of power and competitive harm, the burden shifted to the defendant to show a justification.

In the process Actavis rejected a "quick look" approach urged by the Federal Trade Commission. The Supreme Court, Justice Breyer in particular, has never supported the view that antitrust analysis should be divided into three discrete silos, with "quick look" in between the rule of reason and the per se rule. Rather, he observed, appraising reasonableness in antitrust analysis requires a "sliding scale" that varies the inquiry with the question-a phrase taken from the Antitrust Law treatise. ${ }^{226}$ As the Court observed, a "quick look" was inappropriate in Actavis because the likelihood that a reverse payment would bring about anticompetitive effects: "depends upon its size, its scale in relation to the payor's anticipated future litigation costs, its independence from other services for which it might represent payment, and the lack of any other convincing justification." 227

The Court did not make patent validity or infringement an issue in the antitrust analysis. Nor did it assign the burden of proof on any issue. It would be reasonable, however, to require that once the plaintiff established a large payment in relation to anticipated future litigation costs, the defendant should be required to come forward with information about collateral services and their value, as well as other convincing justifications. This information would most likely be within the defendant's control. At that point the plaintiff could

${ }^{221}$ See 7 AREEDA \& HovenKAMP, supra note 9, qף 1502, 1507; cf. Cal. Dental Ass'n v. FTC, 526 U.S. 756, 786-88 (1999) (Breyer, J., dissenting).

2227 AREEDA \& HOVENKAMP, supra note 9, $₫ 1505$.

223 See 3B AREEDA \& HovenKAMP, supra note 135, ๆ 801; see also Cal. Dental Ass'n, 526 U.S. at 788.

${ }^{224}$ See, e.g., 2B AREEDA \& HOVENKAMP, supra note 135, ๆ 521 (addressing direct proof of market power by estimating residual demand).

${ }^{225}$ See FTC v. Actavis, 113 S. Ct. 2223, 2236 (2013); see also Phillip E. AREEDA \& Herbert HoVENKAMP, ANTITRUST LAW $₫ 520$ (Supp. 2014).

226 Actavis, 133 S. Ct. at 2237-38, (quoting Cal. Dental Ass'n, 526 U.S. at 780 (quoting 7 AREEDA \& HOVENKAMP, supra note 9, ๆ 1507)).

227 Id. at 2237. 
still show that the same objectives could have been achieved by a less restrictive alternative.

In contrast to the rule of reason, antitrust law's per se rule condemns a subcategory of agreements simply upon proof that they have occurred, not requiring proof of market power or actual competitive harm. Today the per se rule is largely reserved for price fixing, naked market divisions, and naked concerted refusals to deal (boycotts). ${ }^{228}$ Once we have decided that the antitrust laws can be applied to a practice involving patents, ordinary antitrust analysis should determine whether the per se rule or the rule of reason should be used. That is to say, this is an antitrust question of law, ${ }^{229}$ not a patent law question.

The involvement of patents may indicate rule of reason treatment in an antitrust case, mainly because the development and dissemination of technology are both "ancillary" practices with potential economic benefits. For example, while a naked product market division agreement is unlawful per se, an agreement embodied in a patent license or cross license may reveal that the firms are sharing a common technology. But this is simply a way of saying that the rule of reason governs "ancillary" restraints, and legitimate technology sharing is a form of ancillarity. Identifying the potential for gains and harm is the purpose of the rule of reason.

Actavis is exceptional in this sense because a pure pay-for-delay settlement is not a license during the delay period but a naked market exclusion that is ordinarily unlawful per se under the antitrust laws. Further, nothing in the Patent Act or Hatch-Waxman Act authorizes pay-for-delay settlements. On top of that, many pay-for-delay settlements involve such attenuated adversity between the parties that they are best regarded as "settlements" in name only. ${ }^{230}$

To that extent Actavis's insistence on a rule of reason still embodies an element of the "beyond the scope of the patent" inquiry. The restraint at issue would have been harmless if the patent were valid and infringed, and the issue is what to make of a very large payment that sends a strong signal of patent invalidity. By contrast, practices such as naked product price fixing are unjustified whether or not the patents in question are valid and infringed.231 The two most salient facts about Actavis's antitrust analysis are, first, that the Court applied the rule of reason, but second, that it recognized and applied the long-standing practice in antitrust cases that even the rule of reason involves presumptions designed to focus the relevant inquiries. ${ }^{232}$

${ }^{228}$ See generally 7 AREEDA \& HovENKAMP, supra note 9, ch. 15; 11-13 id. chs. 1922.

${ }^{229}$ The choice of rule is a question of law, although factual determinations concerning ancillarity may be needed. See 11 AREEDA \& HoVENKAMP, supra note 9, ๆ 1909b.

230 See infra note 251 and accompanying text.

231 See infra notes 258-59 and accompanying text.

${ }^{232}$ See 7 AREEDA \& HovENKAMP, supra note 9, ๆ 1507. 


\section{Settlements}

Most patent infringement suits settle prior to trial. ${ }^{233}$ The settlements often result in production licenses, which the Patent Act authorizes in any event. These would ordinarily be lawful even if there were no infringement litigation to be settled. ${ }^{234}$ When the settlements include provisions that the Patent Act does not authorize, then closer judicial scrutiny is appropriate. ${ }^{235}$ Patents enjoy a statutory presumption of validity, and at the time of a pre-trial settlement this presumption has typically not been upset. ${ }^{236}$ In general, the courts look closely at settlement agreements that include restrictions on the product price, ${ }^{237}$ market division of the product, ${ }^{238}$ or concerted refusals to deal with outsiders. ${ }^{239}$ Purely vertical settlements are generally approved, with some exceptions for exclusive agreements. ${ }^{240}$

The previously discussed "beyond the scope" formulation" 241 for patent practices retains some vitality in judicial opinions involving antitrust challenges to patent settlements. In practice, the formulation has come to mean that a settlement is permissible if its terms are no more exclusionary than a finding of patent validity and infringement would have been. The important thing about most of these disputes is that there is true adversity between the parties. By contrast, adversity is severely limited in the unique subset of settlements in Hatch-Waxman cases involving pharmaceutical drugs, where the joint maximizing course is typically for the two parties to divide the market for as long as the law permits, taking advantage of the Hatch-Waxman provision to exclude everyone else. ${ }^{242}$

233 See Mark A. Lemley, Rational Ignorance at the Patent Office, 95 Nw. U. L. REV. 1495,1501 (2001).

234 See 12 HoVENKAMP, supra note 21, ๆ $2046 \mathrm{~b}$.

235 See Standard Oil Co. v. United States, 283 U.S. 163, 171 (1931) (noting policy of encouraging settlements); see also IP ANTITRUST GUIDELINES, supra note $20, \S 5.5 \&$ Example 10 ("Settlements involving the cross-licensing of intellectual property rights can be an efficient means to avoid litigation and, in general, courts favor such settlements.").

23635 U.S.C. § 282(a) (2012); see also United States v. Line Material Co., 333 U.S. 287, 318-19 (1948) (Douglas, J., concurring) (stating the presumption of validity in assessing a patent settlement but nevertheless striking down resale price maintenance and price-fixing provisions).

${ }^{237}$ United States v. New Wrinkle, Inc., 342 U.S. 371, 373-76 (1952); United States v. Masonite Corp., 316 U.S. 265, 274-77 (1942); United States v. Huck Mfg. Co., 227 F. Supp. 791, 793-94, 803 (E.D. Mich. 1964) (approving the arrangement), aff'd per curiam, 382 U.S. 197 (1965); United States v. Krasnov, 143 F. Supp. 184, 197-99 (E.D. Pa. 1956) (striking down cross-licensing agreement accompanied by product price fixing), aff'd per curiam, 355 U.S. 5 (1957).

${ }^{238}$ Hartford-Empire Co. v. United States, 324 U.S. 570, 574 (1945) (clarifying 323 U.S. $386(1945))$.

239 See United States v. Singer Mfg. Co., 374 U.S. 174, 195 (1963).

240 See infra notes 377-79 and accompanying text.

241 See supra notes 48-66 and accompanying text.

${ }^{242}$ See supra notes 242-47 and accompanying text. 
Pay-for-delay settlements are sometimes thought to be unique because the market division does no more than protect what a valid and infringed patent would have protected in the first place-namely, the patentee's right to exclude the generic. Those defending the agreements have suggested that an agreement whose duration runs short of the time remaining on the patent might actually benefit consumers by permitting quicker generic entry than a valid patent would permit. ${ }^{243}$ The problem with that argument, however, is that there is no equilibrium agreement that would satisfy those conditions without harming consumers. ${ }^{244}$ As noted above, under the dissenter's "scope of the patent" approach the equilibrium point would be an agreement that delayed generic entry just short of the full patent term. ${ }^{245}$

The availability of a pay-for-delay settlement under the Hatch-Waxman Act creates one of the more perverse anticompetitive incentives in the patent system. Such settlements are virtually unknown in patent law outside the context of Hatch-Waxman. ${ }^{246}$ The owner of a pioneer drug whose patent is about to expire is incentivized to create a secondary or extension (evergreened) patent that is just strong enough to get by a patent examiner. ${ }^{247}$ Evergreened patents of this nature have a very high failure rate. ${ }^{248}$ It does not matter how weak the patent is, however; it simply has to be issued. At that point the patentee can enter into a pay-for-delay settlement that ratchets the patent's anticipated success probability up to $100 \%$ because no one can challenge the patent for the duration of the settlement. The result creates a largely impregnable market division because the patent and the product in a pay-fordelay settlement are coterminous: one cannot make the product without the patent. $^{249}$

As noted previously, some have argued that rules disfavoring pay-fordelay settlements might reduce the incentive to develop new drugs. ${ }^{250}$ The only empirical support for that claim is that a longer protection period provides a greater incentive to get a particular patent, but says nothing about overall effects on innovation or the social cost of a longer period of exclusion. On the

${ }^{243}$ See Barry C. Harris et al., Activating Actavis: A More Complete Story, 28 ANTITRUST 83, 83 (2014).

${ }^{244}$ See Edlin et al., supra note 102, at 7.

${ }^{245}$ See supra notes 123-26 and accompany text; see also Hovenkamp, supra note 38 (manuscript at 10).

246 See Hovenkamp, supra note 118, at 15-16.

${ }^{247}$ Kate S. Gaudry, Evergreening: A Common Practice to Protect New Drugs, 29 NATURE BioteChNOLOGY 876, 876-78 (2011) (noting ubiquity of evergreened pharmaceutical patents); see also RoBIn FeLdMan, Rethinking PATENT LAW 170-78 (2012).

248 See Fed. TRAde Comm'N, supra note 125, at viii, 42 (concluding that one out of four of litigated patents in Hatch-Waxman challenges are valid); Eisenberg, supra note 125, at 354; Hovenkamp, supra note 38 (manuscript at 11) (invalidity rate of about two out of three in fully litigated Hatch-Waxman challenges).

${ }^{249}$ See supra notes $214-15$ and accompanying text.

${ }^{250}$ See supra notes $189-92$ and accompanying text. 
other hand, the short-run cost/benefit analysis is overwhelmingly negative. The consistent record of drug prices shows sharp declines upon generic entry. ${ }^{251}$ In any event, the remedy for a patent period that is too short is congressional action lengthening the patent term, not tacking of a bad patent onto a good one.

The Actavis decision creates some unacknowledged tension with the Patent Act's statutory presumption of validity, which gives the challenger the burden to prove invalidity. ${ }^{252}$ In 2011, the Supreme Court agreed with a long line of cases that this presumption could be defeated only by clear and convincing evidence. ${ }^{253}$ At the time of a pay-for-delay settlement a patent has typically not yet been declared invalid; although there are a few exceptions. ${ }^{254}$ Nevertheless, the Court's opinion is driven by an assumption that a high payfor-delay settlement suggests patent weakness. The fact is that the Patent Act's statutory presumption of validity is in conflict with a reality in which nearly half of patents are declared invalid even under the clear and convincing standard. ${ }^{255}$ In any event, the Court's holding that it is not necessary to litigate the patent's validity 256 is consistent with other decisions holding that settlement agreements can be unlawful whether or not the patents in question are valid and infringed. For example, patent validity is not a defense to market wide price fixing in the product market. ${ }^{257}$ This is most likely to be the case when the restraint affects the product market, and when the agreement is not one that the Patent Act authorizes. Both of these things are true of pay-fordelay pharmaceutical settlements. The underlying rationale is that settlements as well as other licensing agreement must be analyzed ex ante, based on the parties' reasonable expectations, rather than ex post by determining after the agreement was entered whether the patent was in fact valid and infringed.

\section{SPECIFIC PRACTICES IMPliCATING ANTITRUST AND PATENT LAW}

This section examines specific post-issuance practices that have implicated both antitrust and patent policy.

251 See, e.g., Jon Leibowitz, Fed. Trade COMM'N, "PAY-FOR-DElay" SETtlements in the Pharmaceutical Industry: How Congress Can Stop Anticompetitive Conduct, Protect Consumers' Wallets, and Help Pay for Health Care Reform (2009), available at http://www.ftc.gov/sites/default/files/documents/public_statements /pay-delay-settlements-pharmaceutical-industry-how-congress-can-stop-anticompetitive-co nduct-protect/090623 payfordelayspeech.pdf, archived at http://perma.cc/2SKP-G92U.

25235 U.S.C. $\S 282$ (a) (2012).

253 Microsoft Corp. v. i4i Ltd. P'ship, 131 S. Ct. 2238, 2242 (2011).

${ }^{254}$ See, e.g., FTC v. Cephalon, Inc., No. 2:08-cv-2141, 2014 WL 3731753, at *8 (E.D. Pa. July 29, 2014) (holding that because patent had already been declared invalid, respondent could not rely on strength of the patent arguments to defend settlement that provided for six year delay).

255 See Lemley \& Shapiro, supra note 156, at 76.

256 FTC v. Actavis, 133 S. Ct. 2223, 2237-38 (2013).

257 See infra notes 267-75 and accompanying text. 


\section{A. Product Price Fixing and Horizontal Market Division}

Naked product price fixing is per se unlawful under the antitrust laws, is condemned by competition authorities everywhere, and can be a criminal offense under United States law. ${ }^{258}$ At the same time, a patent production or use license is a buy-sell agreement that must set a price on the license itself. As a result there is nothing wrong with a license agreement that sets a royalty for the licensee's use of a patent as a lump sum, a percentage of the sales price, a per unit price, or by some other means. The Patent Act expressly authorizes such licenses. ${ }^{259}$

In the Bement v. National Harrow Co. decision the parties went further, however. They settled litigation over patents covering spring-tooth harrows by a cross-license agreement that also stipulated the price at which the harrows themselves must be sold. ${ }^{260}$ The Supreme Court upheld the agreement, reasoning that one element in ownership of a patent is the right to set a product price, which the patentee could retain. ${ }^{261}$ In 1926, the Supreme Court acknowledged a similar exception for an agreement under which General Electric licensed Westinghouse to make light bulbs under its patent and set the price for the bulbs. ${ }^{262}$ Congress repeatedly considered overturning this rule, but without success - a point that three dissenting Justices emphasized in the 1948 Line Materials case. ${ }^{263}$ The majority condemned a market wide price fixing agreement contained in patent cross-licenses. ${ }^{264}$ The basic crosslicensing agreement covered two complementary patents owned by the two principals, but they also agreed to license others to manufacture under the two patents and jointly stipulated the price of the manufactured products.

While Bement and United States v. General Electric Co. (GE) have never been explicitly overruled, today the antitrust enforcement agencies largely ignore them. ${ }^{265}$ In a district court opinion, Judge Richard Posner, sitting by designation, opined that a product price fixing agreement contained in a license settling a patent dispute would be unlawful if the parties believed that the patent was "almost certain" not to survive a validity challenge. ${ }^{266} \mathrm{He}$ also suggested that the "elderly and much-criticized" $G E$ decision would not be

258 See 2 AREEDA \& HOVENKAMP, supra note 135, ๆ $303 \mathrm{~b}$.

25935 U.S.C. $\S \S 261,271(d)(2)(2012)$.

260 See Bement v. Nat'l Harrow Co., 186 U.S. 70, 72-75 (1902). On the technology, see BOHANNAN \& HOVENKAMP, supra note 3, at 354-55.

261 See Bement, 186 U.S. at 93-95.

262 See United States v. Gen. Elec. Co., 272 U.S. 476, 493-94 (1926).

263 See United States v. Line Material Co., 333 U.S. 287, 362-63 (1948) (Burton, J., dissenting).

${ }^{264}$ Id. at 362 n.30 (majority opinion).

265 See IP ANTITRUST GUIDELINES, supra note 20, $\$ 5.2 \&$ n.33 (mentioning GE case in a footnote and emphasizing extent to which courts have narrowed it but not mentioning of Bement).

266 Asahi Glass Co. v. Pentech Pharm., Inc., 289 F. Supp. 2d 986, 991 (N.D. Ill. 2003) (citing 2 HOVENKAMP ET AL., supra note 43, § 31.1c.). 
upheld today, noting that the low royalty rate $(2 \%)$ plus an output escalation clause that served to limit production indicated that the parties were very dubious about the patent and also wanted to fix prices. ${ }^{267}$ In addition, they collectively held $93 \%$ of the light bulb market. ${ }^{268}$ In dicta in Actavis, the Supreme Court restricted $G E$ in a different way, limiting it to agreements between a "single patentee" and a "single licensee." 269 Perhaps a patentee has an interest in limiting price competition from its licensee. ${ }^{270}$ Chief Justice Taft thought so in his $G E$ opinion for the Court. ${ }^{271}$ The patentee could achieve the same result, however, simply by raising the license price. That would permit the patentee to keep the surplus to itself rather than sharing it with the licensee. Of course, the licensee might be unwilling to pay more, but that would suggest that the patent is worth less than the cartel markup in any event.

Neither Judge Posner's restriction to patents of dubious validity nor Actavis's restriction to agreements between a single patentee and a single licensee goes far enough. First, the Actavis limitation might be a useful way of distinguishing $G E$ as judicial precedent, but on the collusion question, the smaller number of players increases rather than decreases the competitive danger, provided the cartel has sufficient power to increase the price. Indeed, a two-person cartel in a duopoly market is typically more stable and thus more dangerous than a cartel composed of a larger number.

Judge Posner's restriction to patents of dubious validity does not address the full problem either. To be sure, including a license in a worthless patent may be a cover for price fixing. But the problem goes far deeper: a product price fix in a patent license agreement attributes the entire value of a monopoly market position to the patents covered in the license agreement. To illustrate, suppose that office staplers can be sold competitively at a price of $\$ 5.00$, but that a monopolist or well-functioning cartel would charge $\$ 7.00$, or $40 \%$ higher. $^{272}$ Suppose that the manufacturers of these staplers identify a minor patent covering one manufacturer's stapler. They form a cross-licensing agreement for that patent, stipulating that each of them will charge $\$ 7$ for staplers. They have in fact merged the legal question about patent validity and infringement and the economic question of patent value into the cartel agreement. Even if the patent were completely valid it may have contributed little value to the staplers in question and certainly not value sufficient to enable the staplers to be sold at a $40 \%$ markup, the full product cartel price.

${ }^{267}$ Id. at 992.

268 Id.

${ }^{269}$ FTC v. Actavis, 133 S. Ct. 2223, 2232 (2013).

270 See BowMAN, JR., supra note 24, at 126-27.

271 See United States v. Gen. Elec. Co., 272 U.S. 476, 490 (1926) ("It would seem entirely reasonable that he should say to the licensee, 'Yes, you may make and sell articles under my patent, but not so as to destroy the profit that I wish to obtain by making them and selling them myself."”).

$272 \mathrm{~A}$ cartel and a purchasing functioning monopolist charge the same price. See HOVENKAMP, supra note $121, \S 4.1$. 
The empirical literature on price fixing overcharges and patent licenses bears this out. In successful cartels the average markup is on the order of $20 \%$ to $50 \%$ over the pre-cartel price, ${ }^{273}$ while average per patent royalty rates on licensed patents run in a range of $1-6 \%$ of the wholesale product price. ${ }^{274}$ One study found the median rate to be about $3 \% .{ }^{275}$ Further, only valuable patents are licensed. Only about $1-2 \%$ of issued patents are ever litigated, and less than $5 \%$ are licensed. ${ }^{276} \mathrm{~A}$ significant majority of patents are not even maintained when renewal fees become due. ${ }^{277}$ But any patent, whether valuable or not, could be used as an excuse for a product price fix if contained in a cartel agreement that the courts permitted. Without regard to the patent's value this agreement would permit the parties to set the price to the full cartel level. That situation resembles the one in Actavis, where the opportunity for

273 See Robert Clark \& Jean-François Houde, The Effect of Explicit Communication on Pricing: Evidence from the Collapse of a Gasoline Cartel, 62 J. INDUS. ECON. 191, 192 (2014); John M. Connor, Cartel Overcharges, in 26 THE LAW AND ECONOMICS OF Class ACTIONS 249, 316 (James Langenfeld ed., 2014); John M. Connor, Price-Fixing Overcharges: Revised 3rd Edition 51, 53, 60 (Feb. 24, 2014) (unpublished manuscript), available at $\mathrm{http}: / / \mathrm{ssrn} . \mathrm{com} / \mathrm{abstract}=2400780$, archived at http://perma.cc/UQ3F-6G9J (detailing statistical data that indicates, among other things, overall median overcharge is $23 \%$; mean overcharge is $48.7 \%$; and international cartel overcharges are higher than domestic ones); John M. Connor \& C. Gustav Helmers, Statistics on Modern Private International Cartels, 1990-2005, at 21 (Purdue Univ. Dept. of Agricultural Econ., Working Paper No. 06-11, 2006), available at http://www.agecon.purdue.edu/working_ papers/workingpaper.connor.11.10.06.pdf, archived at http://perma.cc/T4RJ-AJSZ; Florian Smuda, Cartel Overcharges and the Deterrent Effect of EU Competition Law 4 (Ctr. for European Econ. Res., Discussion Paper No. 12-050, 2012), available at http://ftp.zew.de /pub/zew-docs/dp/dp12050.pdf, archived at http://perma.cc/HTC3-VN2B (finding somewhat lower overcharges than Connor).

274 See KPMG, Profitability AND Royalty RAtes ACROSS Industries: Some PRELIMINARY EVIDENCE 8 (2012), available at http://www.kpmg.com/Global/en /IssuesAndInsights/ArticlesPublications/Documents/gvi-profitability-v6.pdf, archived at http://perma.cc/5Q7Y-EP89 (finding actual royalty rates in the range of $2.6 \%$ to $3.6 \%$ ); Roy J. Epstein \& Paul Malherbe, Reasonable Royalty Patent Infringement Damages After Uniloc, 39 AIPLA Q.J. 3, 4-19 (2011) (noting wide industry-specific variations and indicating problem of distinguishing portfolio rates and single-patent rates; also discussing the often criticized and now generally rejected litigation rule that royalties are presumptively $25 \%$ of the infringer's "profits"); Mark A. Lemley \& Carl Shapiro, Patent Holdup and Royalty Stacking, 85 TEX. L. REV. 1991 (2007) (breaking out single-patent and overall royalty rates, mainly in information technologies); see Uniloc USA, Inc. v. Microsoft Corp., 632 F.3d 1292, 1315-16 (Fed. Cir. 2011) (excluding expert testimony based on $25 \%$ rule: "[t]his court now holds as a matter of Federal Circuit law that the 25 percent rule of thumb is a fundamentally flawed tool for determining a baseline royalty rate in a hypothetical negotiation," in part because of the rule's indifference to patent strength or the number of patents in a portfolio).

275 Mariko Sakakibara, An Empirical Analysis of Pricing in Patent Licensing Contracts 12 (Oct. 2009) (unpublished manuscript), available at http://papers.ssrn.com/sol3 /papers.cfm?abstract_id=1515163, archived at http://perma.cc/58VN-CANE.

276 See Lemley, supra note 233, at 1507.

${ }^{277}$ Id. at $1503-04$. 
collusion eliminates most of the adversity between the parties, permitting them to share the cartel profits. Patent strength could then be reflected in the size of internal cross-licensing royalties. As Judge Posner noted in Asahi Glass, for example, the fact that GE and Westinghouse set a very low royalty rate suggests that the patent was not very strong. ${ }^{278}$

By contrast, suppose that one of the stapler manufacturers has a patent that it believes really does make the staplers worth $\$ 7$, or $\$ 2$ more than the cost of production. The manufacturer could then license the patents to its competitors at a royalty rate of $\$ 2$ per stapler. The output result in this case would be the same, yielding final prices of $\$ 7$, assuming that both manufacturers have costs of $\$ 5$. But this situation is far different because now we have preserved adversity among the parties on the relevant patent questions of validity, infringement, and value. If the rival stapler manufacturer does not believe that the patent is valid, that it is not infringing, or that the patent does not add $\$ 2$ in value, it will not pay. It might try to invent around the patent rather than pay the royalty, but the ability to join a cartel would undermine that incentive as well. This makes this situation very different from Bement or $G E$.

No provision of the Patent Act authorizes product price fixing, and for good reason. But should we apply the rule of reason rather than the per se rule to a naked product price fix contained in a patent license? That might be a compromise between the Bement and GE conclusions of legality and the antitrust rule of per se illegality. It would condemn such price fixes only in cases of significant power and where the price that is fixed is in some way unreasonable.

The problem with a rule of reason in this setting is that it greatly encumbers the analysis of a problem without giving anything in return. As noted above, the harm from a product price fix can occur whether or not the patents are valid or infringed. Quite aside from questions of validity or infringement, they might simply not be worth much, or at least not worth nearly as much as the markup that the fixers agree upon. As a result, asking whether the price fix was no more than reasonably necessary to cover the value of a patent that was valid and infringed would require a very costly and uncertain inquiry into both patent validity and market value - precisely the "sea of doubt" that Judge Taft worried about in his famous defense of the per se price fixing rule, rejecting the defendants' arguments for an inquiry into reasonableness. ${ }^{279}$ Further, in this case the patentee has a perfectly reasonable alternative, which is metering of the royalty rate rather than the product price. The patentee will simply have to convince the prospective licensee that the patent is worth that much.

One qualification to this rule is the Patent Act provision that authorizes domestic horizontal territorial division. ${ }^{280}$ Section 261 authorizes a patentee to

278 See supra notes 265-66 and accompanying text.

${ }^{279}$ United States v. Addyston Pipe \& Steel Co., 85 F. 271, 283-84 (6th Cir. 1898).

2801 HOVENKAMP ET AL., supra note 43, $\$ 24.3 \mathrm{~b}$. 
grant a production license to another firm that covers "the whole or any specified part of the United States." 281 The provision is written in such a way that it covers both horizontal agreements and purely vertical territorial restraints, where the licensor and licensee are not product competitors. ${ }^{282}$ Thus, for example, if the owner of an upstream process patent licenses it to numerous downstream dealers, neither patent policy nor antitrust policy has much reason to attack the arrangement, provided that the licensees are not agreeing with each other. ${ }^{283}$ As far as patent law is concerned, the practice is statutorily authorized. As far as antitrust is concerned, purely vertical nonprice restraints are governed by the rule of reason and few are condemned. ${ }^{284}$

Problematically, however, the provision also insulates purely horizontal territorial restraints where the parties are competitors. These could be per se unlawful under the antitrust laws. In United States v. National Lead Co., the Supreme Court qualified $\S 261$ 's reach, holding that the Sherman Act applies if competing firms disguise a naked horizontal territorial division agreement in patent cross licenses. ${ }^{285}$ In this case the territorial restrictions were worldwide, taking them out of the $\S 261$ authorization, which extends only to domestic territorial division agreements. ${ }^{286}$ In addition, the territorial provisions included licensees' agreements with one another, as well as with licensors. ${ }^{287}$ No provision of the Patent Act authorizes licensees to enter anticompetitive agreements with one another. ${ }^{288}$

Unlike a pay-for-delay settlement, in which the generic does nothing but stay out of the market, $\S 261$ creates an express authorization only for patentees or their assignees to grant a license. ${ }^{289}$ As a result, there will be a level of integration between a competing patentee and licensee, because they are using a common patent to produce something. An ancillary market division

28135 U.S.C. $\S 261$ (2012).

2821 HOVENKAMP ET AL., supra note 43, $\$ 24.3$ b.

283 See Sec. Materials Co. v. Mixermobile Co., 72 F. Supp. 450, 455-56 (S.D. Cal. 1947) (holding it is lawful for patentee to grant one licensee an exclusive right to sell in Southern California and another licensee an exclusive right to sell in other parts of the United States, excluding Southern California and the patentee's own area); see also Becton, Dickinson \& Co. v. Eisele \& Co., 86 F.2d 267, 269 (6th Cir. 1936) (stating in dicta that patentee could license multiple users and limit each to a specified part of the United States).

${ }^{284}$ Cont'1 T.V., Inc. v. GTE Sylvania Inc., 433 U.S. 36, 37 (1977); see also 8 AREEDA \& HovenKAMP, supra note 9, $\uparrow \uparrow$ 1643-1648.

285 See United States v. Nat'l Lead Co., 332 U.S. 319, 341 (1947); see also United States v. Crown Zellerbach Corp., 141 F. Supp. 118, 126-27 (N.D. Ill. 1956) (involving government claim in allegation that patentee and rival used minor patent mechanism in hand-towel dispensers to allocate distribution territories).

28635 U.S.C. $\S 261$.

${ }^{287}$ Nat'l Lead, 332 U.S. at 341-43.

${ }^{288} \mathrm{Id}$. at $341-42$.

28912 HOVENKAMP, supra note 21, ๆ 2044a. 
agreement — unlike the naked territory division in National Lead - would be addressed under the rule of reason. ${ }^{290}$

Finally, § 261 authorizes licenses of the patent, not the entire product in which the patent is embodied. To illustrate, suppose that firm $A$ sells lawn mowers east of the Mississippi River that include a patented handle that purports to be easier to grip. $A$ is free to license firm $B$, another lawn mower seller, to use its patent and to limit use of the handle to mowers sold west of the Mississippi. What $A$ cannot do, however, is forbid $B$ from selling any mowers whatsoever east of the Mississippi. Firm $B$ is free to sell mowers anywhere it wishes provided that it does not incorporate $A$ 's patented handle. Territorial agreements that reach to the product itself are not protected by $\S 261$. If horizontal and naked, they can be illegal per se. ${ }^{291}$

Product and customer market division agreements stand on a different footing from territorial division because they are not authorized by the Patent Act. Such agreements usually take the form of "field-of-use" restrictions, under which a patent is licensed for a particular product or customer set. ${ }^{292}$ Field-of-use restrictions permit a producing patentee to license others for markets that it does not wish to serve with its own production. ${ }^{293}$ Once again, to the extent they involve licenses that are actually producing, they are ancillary restraints with respect to that patent. If the restrictions are imposed by one firm on others the courts generally uphold them under the rule of reason. ${ }^{294}$ For example, in General Talking Pictures v. Western Electric Co., AT\&T reserved the production of sound amplifiers incorporating its patents for commercial use to its own subsidiaries, but it licensed others to produce private versions. ${ }^{295}$ While agreements such as these are horizontal in form, because the patentee competes with the licensees, they are vertical in substance to the extent that the patentee behaves as the manager of the arrangement and is simply licensing other firms to produce in other markets. A close analogy in distribution restraints generally is "dual distribution," in which a producer such as General Motors might own some of its dealerships

290 Compare Nat'l Lead, 332 U.S. at 341-42, with Northrop Corp. v. McDonnell Douglas Corp., 705 F.2d 1030, 1050 (9th Cir. 1983) (remanding to lower court to apply rule of reason and approving product licensing agreement permitting one firm to make land-based military aircraft and the other to make carrier-based aircraft).

2911 HOVENKAMP ET AL., supra note 43, § 24.1b.

29212 HOVENKAMP, supra note 21, ๆ 2044.

293 Id.

${ }^{294} I d$.

295 See Gen. Talking Pictures Corp. v. W. Elec. Co., 304 U.S. 175 (1938), aff'd on reh'g, 305 U.S. 124 (1938). See generally B. Braun Med. Inc. v. Abbott Labs., 124 F.3d 1419, 1427 n.4 (Fed. Cir. 1997) (field-of-use restriction to be evaluated under rule of reason); United States v. Studiengesellschaft Kohle, m.b.H., 670 F.2d 1122, 1128 (D.C. Cir. 1981) (similar); Benger Labs. Ltd. v. R.K. Laros Co., 209 F. Supp. 639, 648-49 (E.D. $\mathrm{Pa}$. 1962) (approving arrangement in which one licensee could manufacture patented drug for veterinary use and another for human use), aff'd per curiam, 317 F.2d 455 (3d Cir.), cert. denied, 375 U.S. 833 (1963). 
while entering into franchise agreements with others. After a lengthy history of debate, ${ }^{296}$ the courts today overwhelmingly regard them as essentially vertical arrangements with significant potential to increase output. ${ }^{297}$

But some field-of-use arrangements cross the line when firms use the restrictions to support collusion. These are closely analogous to other restricted distribution systems in which the product division is instigated by a cartel of dealers or by one powerful dealer. ${ }^{298}$ For example, the HartfordEmpire Co. v. United States decision involved an elaborate product market division agreement among competing glassmakers. The agreement, which settled patent infringement litigation, gave Corning an exclusive right to make pressed and blown glassware, while Hartford received an exclusive right to make other types of glass. Thatcher became the exclusive manufacturer of glass milk bottles, and Ball the exclusive maker of canning jars. ${ }^{299}$ All of the major participants owned patents that were contributed to the cross-licensing agreement, but the agreements themselves applied to the products, not to the patents as such. 300

Dividing the territory between beneficial and harmful field-of-use arrangements brings antitrust policy to one of its most conceptually frustrating issues: how to distinguish vertical from horizontal agreements in the context of restricted distribution. Because the Patent Act does not speak to the issue of product-restricted licenses, antitrust law's rule of reason applies and the issues for patent licenses are not different in principle from the issues for organized product distribution generally. The one important difference is that organized distribution by means of patent licenses may involve technology sharing, while individual product dealers tend to be silos with relatively little interdealer communication. But these are fact questions that antitrust law's rule of reason is designed to address.

\section{B. Pooling, Cross-Licensing, and Standard Setting of Patented Technologies}

Pooling and cross-licensing simpliciter refer to situations in which product-producing firms agree to share technologies for some part of their

296 See, e.g., Pitchford v. PEPI, Inc., 531 F.2d 92, 103-04 (3d Cir. 1975) (classifying dual distribution arrangement as horizontal), cert. denied, 426 U.S. 935 (1976); Hobart Bros. Co. v. Malcolm T. Gilliland, Inc., 471 F.2d 894, 899 (5th Cir. 1973) (similar).

297 See Elecs. Commc'ns Corp. v. Toshiba Am. Consumer Prods., Inc., 129 F.3d 240, 243-44 (2d Cir. 1997); Mesirow v. Pepperidge Farm, Inc., 703 F.2d 339, 342 (9th Cir. 1983); Graphic Prods. Distribs., Inc. v. ITEK Corp., 717 F.2d 1560, 1576 (11th Cir. 1983); Davis-Watkins v. Serv. Merch., 686 F.2d 1190, 1199 (6th Cir. 1982). The case law is analyzed in 8 AREEDA \& HOVENKAMP, supra note 9, 1605.

298 See 8 AREEDA \& HovENKAMP, supra note 9, 11604.

${ }^{299}$ Hartford-Empire Co. v. United States, 323 U.S. 386, 392-400 (1945) (clarified by 324 U.S. 570 (1945)).

${ }^{300}$ Hartford-Empire Co., 323 U.S. at 400. 
production without fixing product prices or dividing the product market. ${ }^{301}$ The agreements can range from specific licenses for specific patents, to licenses for large numbers of patents, to standard setting agreements that involve standards essential patents (SEPs), and up front commitments to license the patents on "fair, reasonable, and nondiscriminatory" (FRAND) terms. In some cases, firms will simply exchange royalty-free licenses to their entire portfolios. ${ }^{302}$

Licensing exchanges that do not restrict products do not often violate the antitrust laws. Such disputes mainly involve either patent law or contract law. Antitrust becomes involved when the restrictions facilitate price fixing, market division, or some other restraint in the product market. Pure patent exclusions can be anticompetitive, however, when firms manipulate the standard setting process to exclude particular technologies that compete with the technologies of members. ${ }^{303}$ Antitrust also becomes relevant when firms combine their patents and use exclusive cross-licenses as a device for excluding others. ${ }^{304}$ Of course, if a standards essential patent is truly essential to network functionality, then a pure patent restriction may also operate as an effective product restriction as well.

A traditional view about antitrust in markets for pooling and cross licensing was that pooling of complementary patents is efficient, while pooling of substitutes is suspicious because it facilitates collusion. ${ }^{305}$ At a high level of abstraction, that observation seems important. Complements are ordinarily used together. Pooling of complements reduces the transaction costs of joint licensing, and also eliminates double marginalization, or royalty "stacking."306 By contrast, if two patents are substitutes they should be competing with one another and the licensee needs one of them, but not both. In that case, pooling is unnecessary to achieve economies and may facilitate collusion.

The substitutes/complements argument often falls apart in practice, however, particularly in information technologies. First, when patents have large numbers of claims, as many information technologies patents do, then dividing them up into substitutes and complements is often impossible. Many patents function as both simultaneously. For example, the Princo Corp. v.

3012 HOVENKAMP ET AL., supra note $43, \S \S 34.2 \mathrm{a}-34.2 \mathrm{~b}$.

302 Id.

303 See infra notes 333-37 and accompanying text.

304 See, e.g., United States v. Singer Mfg. Co., 374 U.S. 174, 196-97 (1963) (condemning cross-licensing to facilitate concerted refusal to exclude rival manufacturers).

305 See Bowman, JR., supra note 24, at 61-63; Richard J. Gilbert, Antitrust for Patent Pools: A Century of Policy Evolution, 2004 STAN. TECH. L. REV. 3, ๆ 89, available at https://journals.law.stanford.edu/stanford-technology-law-review/online/antitrust-patentpools-century-policy-evolution, archived at http://perma.cc/AX82-Z7JT. The literature and case law are exhaustively covered in 2 HovENKAMP ET AL., supra note 43, § 34.

306 See Hovenkamp \& Hovenkamp, supra note 25, at 958-61. Double marginalization, or royalty stacking, occurs when the producers of two complementary products with some monopoly power are unable to coordinate their output. Id. at 958 . The result will be that price will be higher and output lower than under-coordinated pricing. Id. 
International Trade Commission decision involved alternative patents for digital and analog technologies for a portion of a writable CD system that located the stylus on the disc. ${ }^{307}$ A manufacturer would use one technology or the other, but not both, making them function as substitutes. ${ }^{308}$ However, practicing the analog patent required infringement of at least one claim in the digital patent. ${ }^{309}$ This made the patents legal complements as well because effectively they had to be licensed together. ${ }^{310}$

The products that contain pooled patents might be more easily classified as substitutes or complements, but even that is not always clear. One problem with large information technology pools such as MPEG LA, which pools video patents for digital devices, is that the scope of many individual patents has not been determined at the time of licensing. ${ }^{311}$ The members of MPEG LA include manufacturers of personal computers, software, DVD discs and players, memory cards, computer displays, digital televisions, mobile video receivers, TV set-top boxes, Blu-Ray discs and players, digital still video cameras, as well as pay-per-view television technology. ${ }^{312}$ For example, a digital camera and a digital computer display are complements in the product market. One makes photos and the other displays them, so each enhances the value of the other. Nevertheless, these two devices very likely share numerous patents that cover technologies of video digitization and compression. A traditional DVD player and a Blu-Ray player are better classified as substitutes rather than complements. Nevertheless, they undoubtedly share many patents as well. In sum, the complements/substitutes distinction becomes useless in markets with any significant degree of complexity.

In large information technology pools no one knows until after costly claim construction whether or not specific patents write on someone's product. ${ }^{313}$ A paying licensee of the package has little economic incentive to examine each patent in the package for validity or infringement. Even if a patent in the package were declared invalid, there is no legal mechanism short of price regulation that would require a rate reduction.

In such a setting the transaction cost savings from pooling make it far more favorable to most firms than individual enforcement or licensing. 314

${ }^{307}$ See Princo Corp. v. Int'l Trade Comm'n, 616 F.3d 1318, 1322-23 (Fed. Cir. 2010) (en banc).

308 Id. at 1324.

${ }^{309} I d$. at $1324-25$.

${ }^{310}$ Id. at 1325; see also Christina Bohannan, IP Misuse as Foreclosure, 96 Iowa L. REV. 475, 510-11 (2011).

311 Nero AG v. MPEG LA, L.L.C., No. 10-cv-3672-MRP-RZ, 2010 WL 4366448, at *2 (C.D. Cal. Sept. 14, 2010).

$312 \mathrm{See} i d$. at *1. For further details on MPEG LA, see MPEG LA, http://www.mpegla.com/man/default.aspx (last visited Apr. 2, 2015), archived at http://perma.cc

/AR3S-6DFP.

313 See 2 HovenKAMP ET AL., supra note 43, § 34.4a1.

${ }^{314}$ See id. $\S 34.4 \mathrm{c} 4$. 
Indeed, in markets other than chemicals and pharmaceuticals the average value of patents is often less than the cost of acquiring, interpreting, and litigating them. ${ }^{315}$ In that case, widespread pooling becomes a way for firms to "back out" of a patent system that is based on individual appropriation when sharing is a superior alternative. By sharing all of the important technology, they can bring themselves back into an equilibrium with far fewer patents to worry about, except for those held by outsiders to the pool.

A more robust explanation for pooling in high tech markets is rooted in the theory of commons development, in this case the "innovation commons." 316 The legally recognized boundaries of individual property rights are valuable to the extent they reduce the costs of enforcement and in the process increase the value of appropriation. ${ }^{317}$ The clearer boundaries are and the less costly it is to defend them, the more valuable individual property rights will be.

In some cases, however, boundaries are so costly to define and defend that sharing is preferable to individual appropriation. Consider the examples of fisheries and grazing rights, which traditionally experienced a large number of commons dating all the way back to the Middle Ages. ${ }^{318}$ A characteristic of such "common pool resources" is that the cost of defining and defending individual boundaries is very high in relation to production value. ${ }^{319}$ One might imagine that the 100 fishermen owning a common pool could build underwater fences dividing the pool into 100 parts. But doing so would be tremendously expensive, might hamper the movement of the fish with devastating results to the yield, and produce many disputes about the proper location of boundary lines and assignment of parcels. Considering all these impediments, the fishermen obtain a much greater payoff by turning the pool into a commons, developing rules about how much each participant can take out and how much each must contribute.

This phenomenon is simply a special case of Ronald Coase's The Nature of the Firm. ${ }^{320}$ Firms decide on an input-by-input basis how to organize their production, choosing the most cost-effective/highest-payoff alternative. ${ }^{321}$ The Coasean theory of the commons simply says that firms will choose a commons when the payoff to doing so is greater than the payoff to individual boundary setting. ${ }^{322}$

315 See BESSEN \& MEURER, supra note 86 , at 138-42.

316 See BoHANNAN \& HovenKAMP, supra note 3, at 325-64.

317 See id. at 347-49.

318 See ElinOR OSTROM, GOVERNING THE COMMONS: THE EVOLUTION OF InSTITUTIONS FOR COLLECTIVE ACTION 61-88 (1990).

319 See BoHANNAN \& HovenKAMP, supra note 3, at 337.

${ }^{320}$ R. H. Coase, The Nature of the Firm, in 4 ECONOMICA (n.s.) 386, 386-87 (1937). See generally Herbert Hovenkamp, Coase, Institutonalism, and the Origins of Law and Economics, 86 IND. L.J. 499 (2011) (discussing Coase's contributions to the modern discipline of law and economics).

321 See BoHANNAN \& HovenKAMP, supra note 3, at 331.

322 Id. 
Patent pools have some similarities to common pool resources, but they are not identical. One critical difference is that the resources in a traditional common pool are rivalrous, or "subtractive," while output under a patent is not. ${ }^{323}$ For example, fishermen on a common pool risk overfishing, which will deplete the pool. Each has an incentive to take too many out, while contributing too little to restocking and maintenance. As a result, the managers must impose catch limitations on individual members. These quotas look dangerously like cartels, however, and would be unlawful if enforced by a fishing group that did not share a common pool. A patent, by contrast, can be practiced an infinite number of times without depleting the amount that is left over. ${ }^{324}$ As a result, output restrictions in patent pools are more suspicious than they are in traditional common pool resources. ${ }^{325}$ That is a place where antitrust can become relevant, although for the most part large pools for standardized technologies do not impose product output limitations.

Another difference between patent pools and traditional common pool resources has to do with the diversity of both the participants and the patents in the pool. A commons for grazing, fishing, or irrigation rights typically includes participants and rights that are fairly homogenous. Not so with many large patent pools, as the discussion of the MPEG LA pool illustrates. ${ }^{326}$ This can naturally lead to disputes about what should be included in the patent pool. Some manufacturers might want a smaller set of patents, or a different set of patents than other members want.

This phenomenon has led to challenges to a form of "tying," or package licensing, in which a licensee complains that in order to obtain a set of patents that it wants (analogized to the tying product) it must also take a set of patents that it does not want (i.e., the tied product). ${ }^{327}$ Historically the Supreme Court has recognized such claims under the antitrust laws, but today they generally fail for the reason that no injury to competition is present. ${ }^{328}$

Competitive harm from tying occurs when a buyer is forced to take a dominant firm's tied product and as a result cannot purchase that product from a rival. ${ }^{329}$ The "unwanted tied product" claim, by contrast, is simply that the buyer would prefer a smaller package than the one that is being sold. ${ }^{330}$ This

${ }^{323}$ Id. at 328.

324 Id.

325 See id. at 328-30.

${ }^{326}$ Nero AG v. MPEG LA, L.L.C., No. 10-cv-3672-MRP-RZ, 2010 WL 4366448, at *1 (C.D. Cal. Sept. 14, 2010).

327 See id. at *2 (rejecting such a claim).

328 Id. at *4.

${ }^{329}$ See, e.g., Jefferson Parish Hosp. Dist. No. 2 v. Hyde, 466 U.S. 2, 16-18 (1984).

330 See, e.g., Brantley v. NBC Universal, Inc., 675 F.3d 1192, 1200 (9th Cir. 2012) (rejecting claims based on unwanted tied product under rule of reason); see also Herbert J. Hovenkamp, Antitrust and Nonexcluding Ties 3-4 (Univ. of Iowa Legal Studies, Research Paper No. 12-36, 2012), available at http://papers.ssrn.com/sol3/papers.cfm?abstract_id $=2143869$, archived at $\mathrm{http}: / /$ perma.cc $/ 5 \mathrm{~L} 7 \mathrm{~K}-\mathrm{LSHP}$. 
claim may have made some sense in a world in which pools of complementary patents were regarded as beneficial but pools of substitutes were not, and where patents and the technologies incorporating them were easily interpreted. By showing that a particular patent was "unwanted" the plaintiff was establishing that at least for its own use that particular patent was not a complement. By contrast, the theory makes no sense if the reason for pooling is to reduce transaction costs and deal with boundary ambiguities. The plaintiff is asking the court to do precisely the very expensive act that pooling seeks to avoid - namely, establishing and costing out each licensee's individual use.

In any event, it is not antitrust law's purpose to force sellers to cut their product offerings into smaller pieces for the benefit of a customer when no harm to competition is present. Further, accepting the "unwanted tied product" rationale for an antitrust claim turns the court into a micromanager of package size and price. ${ }^{331}$ For example, if the licensee member of a 1000 patent pool protests that its product actually uses only 150 of the patents, a court would have to conduct a fiercely expensive claim construction in order to determine how many patents the plaintiff's product actually practices. Then it would have to determine some pro rata formula for giving the plaintiff a price reduction to account for the patents it does not use. Because all patents are hardly created equal, such evaluations would be enormously costly if not heroic. 332

Patent pooling via standard setting can become anticompetitive for the same reason that standard setting itself might - namely, when it is used to exclude a superior standard for the benefit of incumbent firms who are committed to an established standard. One good example outside of the patent licensing context is the Allied Tube decision. ${ }^{333}$ The Supreme Court found a likely antitrust violation when a group of firms producing traditional steel electrical conduit manipulated a standard setting organization into disapproving plastic conduit, a cheaper and superior product that captured most of the market once the ruling was reversed. ${ }^{334}$ This story has some analogues in patented high technology standard setting. ${ }^{335}$

${ }^{331}$ See, e.g., Broadcast Music, Inc. v. Moor-Law, Inc., 527 F. Supp. 758, 772 (D. Del. 1981).

${ }^{332}$ For a comparison to the copyright context, see $i d$. at 764-65, 767 (rejecting tying claim that country and western bar was forced to take full pool of copyrighted songs in BMI database and holding that costs of cutting up the package and verifying actual use outweighed any gains).

333 Allied Tube \& Conduit Corp. v. Indian Head, Inc., 486 U.S. 492, 509-11 (1988).

${ }^{334}$ Id. at $496-97$.

335 See Golden Bridge Tech., Inc. v. Motorola, Inc., 547 F.3d 266, 270-71 (5th Cir. 2008) (rejecting such a claim); see also TruePosition, Inc. v. LM Ericsson Tel. Co., No. 114574, 2012 WL 3584626, at *25 (E.D. Pa. Aug. 21, 2012) (sustaining a complaint); Cryptography Research Inc. v. Visa Int'l Serv. Ass'n, No. C 04-04143 JW, 2008 WL 5560873, at *6-7 (N.D. Cal. Aug. 13, 2008) (similar). For further analysis, see HovENKAMP ET AL., supra note 43, § 35.6; Hillary Greene, Non-Per Se Treatment of Buyer 
One important thing about technology standard setting is that antitrust must resolve exclusion disputes without becoming unnecessarily involved in the substantive standards themselves. In areas such as telecommunications, electrical, and medical devices, juries are simply not equipped to make such evaluations. But there are other things that a court can examine. For example, competitive harm usually will not result if those setting the standard are not competitors with the person being excluded. As the Seventh Circuit once observed, a standard setting association of boat trailer manufacturers who purchase rather than make their own trailer lights has no anticompetitive incentive to exclude a particular light for failing to meets its standards. ${ }^{336} \mathrm{As}$ purchasers rather than competitors, they stand to benefit from safe, reliable lights, just as consumers would. Second, if the standard setting organization does have participants who compete with the excluded firm there needs to be transparency and, if possible, firewalls that exclude direct competitors from participating in the standard setting process for a competitor's good. ${ }^{337}$

\section{Grantbacks and Market Regimentation}

A grantback clause in a patent license requires the licensee to "grant back" any patented improvements it might make to the invention. ${ }^{338}$ Patentees might regard such a clause as essential before they agree to a license. ${ }^{339}$ Otherwise they might be threatened with obsolescence in the very markets that they have developed. ${ }^{340}$ For example, if patent $A$ were licensed and the licensee then developed a complementary improvement, $B$, that made $A$ work better, the patentee would be stuck with the older version of $A$ unless it were guaranteed access to $B$ as well. ${ }^{341}$ Grantback clauses can be either vertical or horizontal, depending on whether the patentee and licensee are competing producers in the product market.

The Patent Act does not mention grantbacks by name, but the Patent Misuse Reform Act provision applied to tying arrangements includes them. It speaks of a patentee who "condition[s] the license of any rights to the

Price-Fixing in Intellectual Property Settings, 2011 DuKE L. \& TECH. REV. 9ף 66-67 (arguing against per se rule).

336 Moore v. Boating Indus. Ass'ns, 819 F.2d 693, 702-03 (7th Cir. 1987). See generally Herbert Hovenkamp, Standards Ownership and Competition Policy, 48 B.C. L. REV. 87 (2007) (arguing that when government involvement in standard setting is substantial, antitrust challenges generally should be rejected).

337 One situation where these were absent was Allied Tube, 486 U.S. at 496-97. Allied Tube was able to pack a voting meeting with its own employees, instructing them where to sit and how to vote. $I d$. The administrators apparently paid no attention to who was voting or to conflicts of interest.

3381 HOVENKAMP ET AL., supra note $43, \S 25.1$.

${ }^{339}$ Id. $\S 25.2$.

340 Id.

341 See id. $\S 25$. 
patent... on the acquisition of a license to rights in another patent...."342 The statute then provides that this practice should be regarded as unlawful only if "the patent owner has market power in the relevant market for the patent or patented product on which the license or sale is conditioned." 343 The Supreme Court has interpreted this language as requiring proof of market power for antitrust claims of unlawful tying just as much as for misuse claims. ${ }^{344}$ Clearly the same limitation should be applied to grantbacks.

When assessed under the rule of reason, grantbacks are seldom found to be anticompetitive, although harm is possible in a few situations. ${ }^{345}$ "Nonexclusive" grantbacks require that the improvement be licensed back to the patentee but not that it be exclusive. ${ }^{346}$ The district court found competitive harm in such a case when General Electric granted production licenses to a large number of licensees for electric lamp production and made each promise GE a nonexclusive license in all improvements that they made. ${ }^{347}$ The court believed that this could create a patent aggregation monopoly by making GE the only holder of all of the extant technology. ${ }^{348}$ In any event, this strategy would require market dominance in the primary patent, so it should be addressed under the rule of reason with a serious market power requirement. ${ }^{349}$

An exclusive grantback requires the licensee to grant the improvement back to the grantor exclusively. ${ }^{350}$ Such provisions typically permit the innovating licensee to retain a royalty-free licensee to use the improvement itself, but only the original patentee can license the improvement out to others. ${ }^{351}$ One complaint about exclusive grantbacks is that they reduce the licensee's incentive to make and patent improvements, for all it receives is a nonexclusive right to use, which could generate only the competitive return. ${ }^{352}$

34235 U.S.C. $\S 271(d)(5)(2012)$.

343 Id.

${ }^{344}$ See Ill. Tool Works, Inc. v. Indep. Ink, Inc., 547 U.S. 28, 38-39, 41-42 (2006).

345 The only Supreme Court decision on this issue is Transparent-Wrap Mach. Corp. v. Stokes \& Smith Co., 329 U.S. 637 (1947).

3461 HOVENKAMP ET AL., supra note 43, § 25.2.

347 United States v. Gen. Elec. Co., 80 F. Supp. 989, 995, 1016 (S.D.N.Y. 1948).

348 Id. at 1016.

${ }^{349}$ Santa Fe-Pomeroy, Inc. v. P \& Z Co., 569 F.2d 1084, 1100-02 (9th Cir. 1978) (upholding grantback provision giving licensee a royalty-free reserved right on any patented improvements and citing lack of market power); see, e.g., Barr Rubber Prods. Co. v. Sun Rubber Co., 277 F. Supp. 484, 487-95, 505-06 (S.D.N.Y. 1967), aff'd in relevant part, 425 F.2d 1114 (2d Cir. 1970); Old Dominion Box Co. v. Cont'l Can Co., 273 F. Supp. 550, 572-73 (S.D.N.Y. 1967), aff'd, 393 F.2d 321 (2d Cir. 1968); see also IP ANTITRUST GUIDELINES, supra note 20, § 5.6.

3501 HOVENKAMP ET AL., supra note 43, § 25.3.

${ }^{351} I d$.

${ }^{352} I d$ 
The improvement is then more valuable to the original patentee than to the improving licensee. ${ }^{353}$

Exclusive grantbacks can exacerbate the collective action problem present in the 1948 General Electric case, discussed above, by making it impossible for anyone other than the primary patentee to assemble the full technology set. ${ }^{354}$ For example, if GE owned a pioneer lamp patent and placed exclusive grantback clauses in the agreements of ten licensees, each might develop one or more patented improvements. Under an exclusive grantback clause only GE would be able to practice all of the improvements unless it licensed them to the others. In an extreme case a patentee whose patent must be licensed to every market participant would be in a position to acquire an exclusive right to every patent developed for the industry by its existing participants. If the technology is "rolling" with frequent ongoing patenting, such a restraint could perpetuate the patentee's dominant position indefinitely. This could enable the patentee to restrict total market output to the monopoly level while imposing competitive rates of return on its licensee rivals. Once again, this is a dominant firm strategy that must be tested under antitrust law's rule of reason. ${ }^{355}$

\section{Purely Vertical Practices}

A practice is purely vertical if none of the parties to any agreement are competitors. ${ }^{356}$ Instead, they stand in a buyer-seller relationship. As noted previously, most of the "nine no nos" from the 1970s era were vertical practices, including such things as tying, exclusive dealing, and resale price maintenance. ${ }^{357}$ The law in most of these areas has changed, although for reasons that have little to do with patent policy. In most cases no harm to competition can be shown. Prior to the 1990s much of the perceived conflict between antitrust and patent law resulted from routine antitrust condemnation of competitively harmless vertical practices. Today purely vertical agreements are addressed under the rule of reason in virtually all contexts, including IP licensing agreements and settlements. ${ }^{358}$ To the extent that a vertical settlement involves a production license to the infringement defendant, it is

${ }^{353} \mathrm{Id}$.

354 Id.

355 One possible situation occurred in Kobe Inc. v. Dempsey Pump Co., 198 F.2d 416, 420, 423-25 (10th Cir. 1952) (finding an unlawful attempt to monopolize in the primary patentee's use of exclusive grantbacks to acquire all new patents in the industry).

3561 HOVENKAMP ET AL., supra note $43, \S 20.1$.

357 See supra notes 15-16 and accompanying text.

358 See generally NYNEX Corp. v. Discon, Inc., 525 U.S. 128 (1998) (requiring rule of reason treatment for purely vertical exclusion agreements); United States v. Studiengesellschaft Kohle, m.b.H., 670 F.2d 1122 (D.C. Cir. 1981) (similar). The rule of reason was applied to vertical nonprice restraints in 1977 and to resale price maintenance in 2007. See Cont'l T.V., Inc. v. GTE Sylvania Inc., 433 U.S. 36, 59 (1977) (vertical nonprice restraints); Leegin Creative Leather Prods., Inc. v. PSKS, Inc., 551 U.S. 877, 881-82 (2007) (resale price maintenance). 
authorized by the Patent Act in any event, provided the agreement does not explicitly restrain output in the product market. 359

The major antitrust concern is vertical agreements that limit the sales of rivals, principally tying, exclusive dealing, and similar practices. ${ }^{360}$ Tying arrangements are competitively benign in most cases, even when one of the products is patented and, significantly, even when the defendant has market power in the tying product. ${ }^{361}$ Exclusive dealing raises competitive concerns only when relatively strict structural requirements are met. ${ }^{362}$

The Supreme Court has not strictly overruled its numerous declarations that tying is unlawful per se. ${ }^{363}$ In Illinois Tool Works v. Independent Ink, Inc. the Court came close, but in fact struck down only a per se presumption that tying of a patented product is per se unlawful without an independent showing of power. ${ }^{364}$ The decision is perhaps a strong signal that the Supreme Court is prepared to abandon the tying per se rule in an appropriate case.

The list of vertical practices still requiring antitrust examination also includes a few package licenses and related practices, as well as some grantbacks, but only when they facilitate anticompetitive exclusion or collusion. ${ }^{365}$ Of particular concern are vertical restraints initiated by licensee cartels or powerful individual licensees. ${ }^{366}$ What these practices have in common is a firm that is dominant and a practice that in actual effect is "horizontal" in that it either limits the opportunities of rivals or facilitates collusion. Further, while a patentee typically has an incentive to maximize output by its licensees, individual licensees or cartels of licensees may have an incentive to reduce output to the monopoly level. Traditionally these practices are assessed under both $\S 1$ and $\S 2$ of the Sherman Act as well as $\S 3$ of the Clayton Act if commodities are involved. Section 1 of the Sherman Act and

${ }^{359}$ Vertical practices involving patent and other IP rights are discussed in 1 HOVENKAMP ET AL., supra note 43, §§ 20-25. On vertical practices generally, including those that implicate patents, see 6-11 AREEDA \& HovENKAMP, supra note 9, §§ 14, 16-18 (addressing agreement, intrabrand restraints, tying, and exclusive dealing).

3601 HOVENKAMP ET AL., supra note 43, § 21.1.

361 Id.

362 See 11 HovenKAMP, supra note 9, 11821.

${ }^{363}$ See, e.g., Jefferson Parish Hosp. Dist. No. 2 v. Hyde, 466 U.S. 2, 9-12 (1984); N. Pac. Ry. Co. v. United States, 356 U.S. 1, 8 (1958); Int'l Salt Co. v. United States, 332 U.S. 392, 396 (1947), abrogated by Ill. Tool Works, Inc. v. Indep. Ink, Inc. 547 U.S. 28 (2006). See generally 8 AREEDA \& HovenKAMP, supra note 9, $\uparrow 1620$ (tracing origin and rationale of per se tying rule).

364 Ill. Tool Works, 547 U.S. at 42.

365 See supra notes 15-28, 307-13 and accompanying text.

366 On the role of dealer cartels or powerful individual dealers, see 8 AREEDA \& HovenKAMP, supra note 9 , $\uparrow 1604$. 
the corresponding Clayton Act provision both require an agreement, ${ }^{367}$ but $\S 2$ of the Sherman Act does not.

One of the most important developments in the recent antitrust analysis of vertical practices is the courts' movement away from agreement-based models of harm for supplier (licensor) imposed practices, and toward dominant firm models. ${ }^{368}$ This movement reflects two important realities. First, conduct involving exclusivity obligations imposed on downstream firms is in fact unilaterally imposed, notwithstanding that most of the time it is contained in an agreement, such as a franchise contract or an IP license. The "agreement" requirement adds nothing other than an explanation for the dominant firm's leverage over downstream firms. In some interbrand restraint cases a relevant agreement is impossible to prove, such as when the seller refuses to sell separate components individually or refuses to sell to dealers who are already selling the products of competitors, or when the two products are bound together by technological design. ${ }^{369}$ The result is that legality too often depends on the happenstance of an agreement only because of the statutory structure. Second, vertical exclusion is a dominant firm practice, in which market power is much more relevant to competitive harm than the existence vel non of an agreement.

I have argued elsewhere that $\S 2$ is actually a better fit for these practices because they are best assessed as the unilateral actions of a dominant firm. ${ }^{370}$ In fact, failure to insist on a reasonable showing of anticompetitive exclusion explains much of the antitrust overreaching that occurred in the 1980s and before. Having found a qualifying "agreement," the courts were content to condemn the practice on a much lower market share than they would have required for a $\S 2$ dominant firm case.

Of course, exclusive patent licenses can be collusive-but this occurs when the licensor or licensee are competitors, or would be competitors but for the license. The other collusion danger is cartel agreements among licensees, but these are not authorized by the Patent Act and can readily be addressed under ordinary antitrust rules for horizontal restraints. ${ }^{371}$

While $\S 261$ of the Patent Act authorizes exclusive licenses, it does not explicitly authorize anticompetitive exclusive licenses. Does it do so implicitly? In other contexts the general creation of granting or transacting powers does not imply a right to violate the antitrust laws. For example, all business corporations have a power to enter into contracts or acquire property, but that does not imply a power to make anticompetitive contracts or

367 See 15 U.S.C. $§ 1$ (2012) (using the terms "contract," "combination," or “conspiracy"); 15 U.S.C. $§ 14$ (2012) (using the phrase "condition, agreement, or understanding").

368 See, e.g., United States v. Microsoft Corp., 253 F.3d 34, $68-69$ (D.C. Cir. 2001); United States v. Dentsply Int'1, Inc., 399 F.3d 181, 191-92 (3d Cir. 2005).

369 See 10 AREEDA \& HOVENKAMP, supra note 14, $9 \uparrow$ 1753-1757.

37011 AREEDA \& HOVENKAMP, supra note 9, $\uparrow 1800 \mathrm{c5}$.

${ }^{371}$ See supra notes 265-74 and accompanying text. 
acquisitions that violate the antitrust laws. Mere legality under corporate or contract law does not imply antitrust legality. .372

In any event, whether $\S 261$ authorizes anticompetitive exclusive licenses is partially settled by $\S 3$ of the Clayton Act, which reaches exclusive dealing and tying of goods "whether patented or unpatented," provided that the requisite harm to competition is proven. ${ }^{373}$ That does not fully address the $\S 261$ issue, however, because the Clayton Act provision is limited to "goods, wares, merchandise, machinery, supplies, or other commodities . ..."374 A patentee might still grant an exclusive license of a process patent, which would not be covered by the Clayton Act provision. By negative implication the Patent Act also permits antitrust challenges to anticompetitive ties, provided that the tying patentee has market power in the tying patent. ${ }^{375}$ In sum, the $\S 261$ authorization of exclusive licenses should be limited to exclusive licenses that are not anticompetitive. ${ }^{376}$

When exclusive licensing does cause anticompetitive harm it is frequently at the behest of the licensee, who is the beneficiary of the exclusivity provision, rather than the licensor. For example, a dominant firm in a technology heavy product market might acquire exclusive licenses in order to keep rivals from having access. ${ }^{377}$ Section 261 of the Patent Act expressly permits IP rights holders (both patentees and assignees) to "grant and convey an exclusive right," but says nothing about receiving such a right. ${ }^{378}$ Even if this provision protected anticompetitive exclusive selling of IP licenses, it does not necessarily protect anticompetitive buying. Once again, the statute should be read to permit only those exclusive licenses that are not anticompetitive.

Limiting antitrust condemnation of vertical practices to those involving exclusion or collusion throws out two important sets of tying and tying-like

372 The point was recently reiterated in FTC v. Phoebe Putney Health Sys., Inc., 133 S. Ct. 1003, 1012 (2013). However, it stretches back a century earlier. See United States v. Union Pac. R.R. Co., 226 U.S. 61, 86 (1912) (finding that the fact that transaction was lawful under corporate law did not immunize it from Sherman Act merger challenge). See generally 1 AREEDA \& HOVENKAMP, supra note 135, ๆ $102 \mathrm{~b}$.

37315 U.S.C. $\S 14$ (2012).

${ }^{374}$ Id.

37535 U.S.C. $\S 271(\mathrm{~d})(5)(2012)$.

376 See Cnty. Materials Corp. v. Allan Block Corp., 502 F.3d 730, 739 (7th Cir. 2007) (stating that noncompete agreement is similar to exclusive dealing, not patent misuse and there is no injury to competition); Columbus Auto. Corp. v. Oldberg Mfg. Co., 387 F.2d 643, 645 (10th Cir. 1968) (assuming that exclusive dealing requirement in patent license constituted patent misuse); Nat'l Lockwasher Co. v. George K. Garrett Co., 137 F.2d 255, 256 (3d Cir. 1943) (similar). But see Monsanto Co. v. Scruggs, 342 F. Supp. 2d 568, 58182 (N.D. Miss. 2004) (assuming that exclusive agreement in patent license could be challenged under antitrust laws but not finding illegality).

377 See, e.g., United States v. Am. Can Co., 230 F. 859, 889-91 (D. Md. 1916) (condemning defendant for a variety of practices, including acquisition of exclusive patent rights).

37835 U.S.C. $§ 261$ (2012). 
practices that the courts have historically recognized. The first is claims involving leverage, while the second involves unwanted tied products.

The leveraging issue is often muddled by its confusion with foreclosure and price discrimination. In its most basic form the claim is that a person with a monopoly in one product can earn a second monopoly profit by tying a complementary good. ${ }^{379}$ Stated in this way, the leveraging claim was thoroughly exploded in the 1950s by Ward Bowman, who observed that consumers of complementary goods place a value on the package rather than its individual components. ${ }^{380}$ As a result, if a seller is already charging its profit-maximizing price for a tying product it cannot earn more by tying a complement and charging a second monopoly price. ${ }^{381}$ Consistent with profitmaximization, the seller can increase the price of the second product only by reducing the price of the primary product. ${ }^{382}$ To be sure, tying can create opportunities for price discrimination, which can resemble leverage, but the great majority of price discrimination ties are efficient. 383

Ties and package licensing, which is sometimes analogized to tying, can be used for a number of purposes unrelated to exclusion or collusion. These include quality control, maintenance of interoperability, elimination of double marginalization, price discrimination, economies of joint production or distribution, or transaction cost savings. Many of these effects are identical with those of pooling. The main difference is that a pool is an agreement among numerous patentees while a package license contains one patentee with a portfolio of patents and numerous licensees. ${ }^{384}$ Most antitrust challenges to package licensing do not involve exclusion but rather are complaints that the patentee is required to take unwanted patents. ${ }^{385}$ As noted in the discussion of pooling, however, after years of wrestling with the issue the courts are now starting to see that forcing a buyer or licensee to take an unwanted product is not an antitrust problem. ${ }^{386}$

In a few exceptional cases, the impact of package licensing is to exclude a rival by forcing it to compete with a price of zero. ${ }^{387}$ For example, suppose firm $A$ licenses a package of several patents on an all-or-none basis. One of those patents is $X$, and a rival holds patent $X^{\prime}$, a substitute that may be superior to $X$ for some users. From the licensee's perspective, however, $X$ is already

${ }^{379}$ See Carbice Corp. of Am. v. Am. Patents Dev. Corp., 283 U.S. 27, 31 (1931).

${ }^{380}$ Bowman, Jr., supra note 23, at 20.

$381 \mathrm{Id}$

382 Id.

${ }^{383}$ Compare Hovenkamp \& Hovenkamp, supra note 25, with Einer Elhauge, Tying, Bundled Discounts, and the Death of the Single Monopoly Profit Theory, 123 HARV. L. REV. 397 (2009).

3841 HOVENKAMP ET AL., supra note $43, \S 22.1$.

385 Id. $\S 22.7$.

386 See, e.g., Brantley v. NBC Universal, Inc., 675 F.3d 1192, 1195 (9th Cir. 2012); see also supra notes $289-305$ and accompanying text.

387 See 1 HOVENKAMP ET AL., supra note $43, \S 22.8$. 
included in the package and the licensee will not receive a royalty reduction if it does not practice $X$ but instead switches to $X{ }^{\prime}{ }^{388}$ Even so, inclusion of $X$ in the package license is not necessarily illegal. First, there may still be costs associated with verifying whether licensees are practicing $X$, or whether or not they are also practicing $X^{\prime}$. Second, inclusion of $X^{\prime}$ in the licensee's technology may create conflicts with the other patents in the package. Third, relief might require a court to compute the requisite downward adjustment in the royalty rate for a package that does not include patent $X .{ }^{389}$

In some situations these problems can be addressed. One example, although it did not involve package licensing as such, was Microsoft's "per processor" licensing contract with computer manufacturers. ${ }^{390}$ Microsoft's standard licensing agreement for Windows required computer manufacturers to pay the Windows license fee on every computer it made, whether or not the computer actually used Windows. ${ }^{391}$ The result was that if a computer manufacturer wanted to install a rival's operating system that computer would be subject to two licensing fees. In this case Microsoft entered a consent decree requiring it to abandon per-processer licensing and charge a fee only on computers that actually installed the Windows Operating System. ${ }^{392}$

Would an injunction against a patent package that forbids inclusion of patents with competitive alternatives be procompetitive? Suppose that a licensor of a package of 100 patents includes one patent $X$. A rival patentee holding a substitute patent $X^{\prime}$ claims anticompetitive foreclosure. The court responds with an injunction requiring the defendant to drop $X$ from its package. If the court simply removes patent $X$ from the package without ordering a price reduction, then whether the patentee cuts the price will depend on competitive constraints. If it does not cut the price, however, then all licensees will simply end up paying more. On the other hand, if the court must determine and order a price reduction, it is placed in the unacceptable position of price regulator of the value of that patent. Finally, the mere fact that a licensee practices patent $X^{\prime}$ does not entail that it is not also practicing patent $X$ - not in a world in which patents have numerous, often overlapping, claims.

This discussion suggests two warnings about the antitrust analysis of vertical arrangements. The first is that courts and enforcers should be aware of the ubiquitous possibilities that vertical practices create for achieving operational and transactional efficiencies. This makes it imperative that market power requirements be taken seriously and that courts understand the rationale for a practice. A second warning is that it does no good to identify a practice

388 See Grid Sys. Corp. v. Tex. Instruments Inc., 771 F. Supp. 1033, 1039-41 (N.D. Cal. 1991) (alleging facts that stated a Sherman Act claim).

389 See 10 AREEDA \& HovENKAMP, supra note 14, $1782 \mathrm{a} 2$.

390 See, e.g., United States v. Microsoft Corp., 56 F.3d 1448, 1462-63 (D.C. Cir. 1995) (per curiam).

391 Id. at 1451.

392 Id. at 1462. 
as an antitrust violation if the court is unable to devise an effective antitrust remedy, and judicial setting of prices is rarely that.

\section{E. Royalty "Extensions"}

Royalty "extensions" refer to practices in which the basis for royalties is something other than the typical percentage of cost or price, or a fixed dollar amount of each unit sold or each time a device covered by a valid patent is used. The most common and commonly litigated examples are: (1) provisions that require the payment of a royalty beyond the expiration date of the patent; 393 (2) provisions that assess royalties on goods that are not covered by the licensed patent but that are produced with a patented machine or process; (3) "reach through" royalties that are attached to final products produced with a patented research tool or process; or (4) royalties assessed on a producing licensee's entire output of some product, whether or not individual units of that product actually practice that patent. The courts assessing these practices have often relied on "scope of the patent" formulations.

Royalty extensions are not explicitly authorized by the Patent Act, so antitrust analysis is appropriate. Nevertheless, the practices are almost always purely vertical and are anticompetitive in only a few situations. Further, most of them are not obviously offensive to patent policy's concern with promoting innovation either.

In Brulotte v. Thys Co., a divided Supreme Court refused to enforce a sales contract for a hop-picking machine that called for the payment of royalties beyond the date that the last patent on the machine expired. ${ }^{394}$ The patentee was not the seller of the machine, but rather had licensed its patents to the manufacturer who then used a reach-through provision to charge the license fee to the purchaser. ${ }^{395}$ While Brulotte was clearly not an antitrust case, it was not strictly speaking a misuse case either. Ordinarily misuse is asserted as a defense to patent infringement. In this case, however, the royalty extension was challenged in a state contract law action to enforce the royalty provision. ${ }^{396}$ In any event, Justice Douglas' opinion for the Court used antitrust-like language to speak of the provision as leveraging the patent

${ }^{393}$ See, e.g., Brulotte v. Thys Co., 379 U.S. 29, 30 (1964). For decisions applying Brulotte, often while criticizing it, see Kimble v. Marvel Enters., Inc., 727 F.3d 856, 857 (9th Cir. 2013), cert. granted, 135 S. Ct. 781 (2014); Zila, Inc. v. Tinnell, 502 F.3d 1014, 1016 (9th Cir. 2007); Scheiber v. Dolby Labs., Inc., 293 F.3d 1014, 1017 (7th Cir. 2002); Meehan v. PPG Indus., Inc., 802 F.2d 881, 883-86 (7th Cir. 1986). See generally 1 HOVENKAMP ET AL., supra note 43, § 23.2 .

${ }^{394}$ Brulotte, 379 U.S. at 30.

395 Id.

${ }^{396} \mathrm{Id}$. 
"monopoly" beyond the scope of the patent. ${ }^{397}$ The dissent also spoke of the issue as involving patent misuse. ${ }^{398}$

No monopoly was being extended, however. The challenger did not wish to produce Thys' machines, and once the patents expired anyone could have done so. ${ }^{399}$ Indeed, to the extent that Brulotte, a farmer, was required to pay a per use royalty 400 on the Thys machine, he would have an increased incentive to obtain a machine from a competitor. Just as was true of many patent misuse cases, the underlying theory was based on a conception of harm that had little to do with either competition or innovation.

The majority also ignored the extent to which nominal license payments perform an amortization function when they are attached to patented goods. If I buy an automobile and agree to pay for it over ten years, the price has been set up front and the payments operate in satisfaction of a loan or lease. Monthly payments will not decline as patents expire. This ultimately reduces the Brulotte problem to one of contract drafting, and the relatively few situations that have run afoul of it largely fall into that camp. ${ }^{401}$ Otherwise the implications would be that if someone leased a car for, say $\$ 100$ per month plus five cents per mile, she would be entitled to a pro rata price reduction to account for any patent that expired during the lease period. Justice Harlan's dissent made this point rather forcefully. ${ }^{402}$

Nevertheless, whether Brulotte should be overruled after a half century is debatable. The argument for reversal rests on the logic that patent "misuse" should be defined by antitrust principles. Brulotte's rationale makes little sense on antitrust grounds because in most cases involving post-expiration royalties nothing is being monopolized.

Forceful counter-arguments exist, however, although they may apply in only a few situations. For example, perhaps all of the sellers in a market have a license from the patentee that requires post-expiration royalties, and new entry into this market is unlikely. In that case the payment of post-expiration royalties could serve to raise prices across the market, harming consumers without serving patent policy. The Ninth Circuit's decision in Kimble v. Marvel Enterprises Inc. represents a related possibility. The patent in question was on a toy "Spiderman" hand that enabled a child to pretend to throw a sticky web as Spiderman did in Marvel comic books and movies. ${ }^{403}$ Once the patent expired another firm could employ the invention, but that would not

397 Id. at 33.

398 See id. at 38 (Harlan, J., dissenting).

399 Id. at 32 (majority opinion).

400 The royalty stipulated in Brulotte's contract was $\$ 3.33$ per 200 pounds of dried hops harvested, subject to a minimum of $\$ 500$ annually over the life of the contract. Brulotte, 379 U.S. at 29.

401 See, e.g., Scheiber v. Dolby Labs., Inc., 293 F.3d 1014, 1016 (7th Cir. 2002).

402 Other decisions are discussed in 1 HovENKAMP ET AL., supra note 43, $\$ 23.2$.

403 Kimble v. Marvel Enters., Inc., 727 F.3d 856, 858 (9th Cir. 2013), cert. granted, 135 S. Ct. 781 (2014). 
give it access to Marvel's trademarks, which last indefinitely, or other intellectual property rights. As a result the patent might be worth very little to anyone other than Marvel, and the impact of the license fee agreement could be to force an overcharge on the toy indefinitely. Consumers could be harmed.

One problem with Brulotte, however, is that while post-expiration royalties may be harmful in some cases, Brulotte does not require any kind of evaluation of market structure or post-expiration market effect. The rule is per se and applies in competitive and monopolized markets alike. As a result it does not distinguish the occasional harmful use, such as Kimble, from the much larger number of cases that are harmless.

Second, one can usually evade the Brulotte trap by careful license agreement drafting that separates out the patent and nonpatent portions of an arrangement.

Third, and more fundamentally, while Brulotte may not be justifiable on antitrust grounds, it may nevertheless serve a useful purpose within patent law, which is properly concerned about arrangements that tie up property rights once patents have expired. Patent law's "first sale" doctrine performs an analogous function, by refusing to enforce licensing restrictions on a patented article after that article has been sold. ${ }^{404}$ Clearly, the concern is not economic monopoly, because the doctrine applies to sales of a single article. The first expression of the first sale doctrine was in a decision that refused to apply a congressionally enacted patent term extension to a machine that had already been sold and for which the patentee sought to apply the extension retroactively. ${ }^{405}$ Brulotte is really nothing more than a variant of the first sale doctrine, applied to post-expiration royalties.

Finally, Congress has the power to overrule Supreme Court statutory decisions that it disapproves. Most particularly, twenty-five years after Brulotte it amended the Patent Act to make clear that refusals to license are not patent misuse, and that tying arrangements are unlawful only in the presence of tying product power. ${ }^{406}$ It said nothing about Brulotte, however. Even though Brulotte's per se rule may not be justified by either competition or patent policy, its long duration and Congress's failure to correct it cautions against a change now.

Royalties on unpatented goods or attached to a licensee's entire output, whether or not every unit embodies the licensed patents, rarely offend either antitrust or patent policy. Many situations operate as nothing more than per

${ }^{404}$ See, e.g., Quanta Computer, Inc. v. LG Elecs., Inc. 553 U.S. 617, 625 (2008); Adams v. Burke, 84 U.S. (17 Wall.) 453, 456 (1873); see also Hovenkamp, supra note 49, at 491.

405 See Bloomer v. McQuewan, 55 U.S. (14 How.) 539, 550-51 (1852); see also Hovenkamp, supra note 48, at 57.

40635 U.S.C. $\S 271(\mathrm{~d})(4)-(5)$ (2012). The Government's amicus brief urging the Court to adhere to the Brulotte rule made this point forcefully. See Brief for United States as Amicus Curiae Supporting Respondent, Kimble v. Marvel Enters., 135 S. Ct. 781 (2015) (No. 13-720), 2015 WL 981525, at*19 n.3. 
use royalties calculated by an alternative method. Others involve transaction cost savings in situations where it is difficult to identify which units of a licensee's output practice a particular patent.

For example, the owner of a large portfolio of patents covering radio circuitry might license them to a radio manufacturer with the royalty calculated as so much per radio produced, regardless of how many of the patents are actually used in that particular radio. This agreement clears the transaction at far lower cost than an alternative that would require inquiry and perhaps litigation over the question of exactly how many patents are practiced by any particular unit. Neither collusion nor exclusion is likely. ${ }^{407}$ Indeed, even if we believed that patent law had a concern with "extraction" as suchthat is, with obtaining elevated royalties - it is hardly clear that these royalty formulations extract. Most are a form of second-degree price discrimination that tends to collect higher royalties from higher intensity users. Whether licensees are harmed on balance would be extraordinarily difficult to determine, but certainly cannot be inferred. Virtually all such schemes serve to increase total output and, typically, the total number of licensees as well. 408 Output increasing practices are not good candidates for antitrust violations.

"Reach through" royalties operate in much the same way, with the added attribute that they can be an effective risk-sharing device. For example, the seller of a research machine or tool for laboratory use might grant the right to use the machine without charge but demand a percentage of the sales price of any successful product that is developed with the machine. If the research venture is unsuccessful, as is often the case, then no royalty is due. If it succeeds, then the royalty could end up being quite high, particularly if demand for the invention is strong. Such a contract permits the licensor of the machine to participate in the risks and benefits of the research in question. As a general proposition, the arrangement is no more anticompetitive than if the research team agreed to hire a specialist or accept an investor whose compensation was a percentage of the return on the final product. Although the practice has generated some controversy in the law reviews, particularly

407 See Automatic Radio Mfg. Co. v. Hazeltine Research, Inc., 339 U.S. 827, 832 (1950); see also Miller Insituform, Inc. v. Insituform of N. Am., Inc., 605 F. Supp. 1125, 1133 (M.D. Tenn. 1985) (upholding royalty based on final customer price, which covered a combination of the patented good, labor, and other services), aff'd, 830 F.2d 606 (6th Cir. 1987).

408 On the economics, see Hovenkamp \& Hovenkamp, supra note 25. For coverage of the cases, see 1 HOVENKAMP ET AL., supra note 43, $§ 21$. 
because it may contribute to double marginalization or royalty "stacking,"409 the courts have generally treated it as benign. ${ }^{410}$

\section{F. Antitrust and Patent Enforcement}

Merely "obtaining" a patent improperly is pre-issuance conduct that is not generally addressable through antitrust law. ${ }^{411}$ First, the patent system itself provides for comprehensive regulatory oversight with virtually all issuance decisions made by government officials and supervised on appeal by judges. Second, the patent system includes its own remedial mechanisms for dealing with improper conduct, mainly through declarations that a patent is invalid or unenforceable. This system has been harshly criticized, in part because a mere declaration of invalidity as punishment on a patent that was invalid to begin with is not really a punishment at all. ${ }^{412}$ For example, if a patent would not be issued if the true facts were known, then an applicant has every incentive to hide an essential fact when the probability of detection is less than $100 \%$ and the only penalty is that the patent is unenforceable. Indeed, in the case of a licensed patent later invalidated for inequitable conduct, the Patent Act does not even call for disgorgement of improperly obtained royalties. ${ }^{413}$ It is the rough equivalent of a criminal rule for theft that required as its only penalty that the thief return the stolen good.

While lax treatment of inequitable conduct is a significant problem for the patent system, that does not make it an antitrust problem-unless the inequitable conduct before the Patent and Trademark Office (PTO) is coupled with some post-issuance conduct as well, such as an infringement action,

${ }^{409}$ See, e.g., Robin C. Feldman, The Insufficiency of Antitrust Analysis for Patent Misuse, 55 Hastings L.J. 399, 440-41 (2003); Alfred C. Server et al., Reach-Through Rights and the Patentability, Enforcement, and Licensing of Patents on Drug Discovery Tools, 1 Hastings SCI. \& TECH. L.J. 21, 28 (2009). But see Bohannan, supra note 310, at $520 \mathrm{n} .170$ (distinguishing royalty stacking from reach-through royalties).

410 See, e.g., Bayer AG v. Housey Pharm., Inc., 228 F. Supp. 2d 467, 470 (D. Del. 2002) (holding that a reach-through royalty is not patent misuse).

411 See FMC Corp. v. Manitowoc Co., 835 F.2d 1411, 1418 n.16 (Fed. Cir. 1987) (distinguishing "mere procurement" of a patent from subsequent enforcement and stating that the former cannot be an antitrust violation); see also Cygnus Therapeutics Sys. v. ALZA Corp., 92 F.3d 1153, 1161 (Fed. Cir. 1996) (holding that procurement of patent by fraud cannot establish an antitrust violation absent evidence of any action toward enforcement of a patent).

412 Compare Tun-Jen Chiang, The Upside-Down Inequitable Conduct Defense, 107 Nw. U. L. REV. 1243, 1252-53 (2013), with John F. Duffy, The Inequities of Inequitable Conduct: A Case Study of Judicial Control of Administrative Process, 51 Hous. L. REV. 417, 419-20 (2013) (acknowledging Chiang's claim but showing that in other cases the defense overreaches).

413 See Allison Pruitt, Note, Keeping Patent Applicants Honest: A Proposal to Apply Disgorgement Remedies to Findings of Inequitable Conduct During Patent Prosecution, 13 J. INTELL. PROP. L. 465, 487-88 (2006) (arguing for the use of the disgorgement remedy for acts of inequitable conduct during patent prosecution). 
threat of an infringement suit, or insistence on licensing. Housekeeping inside the PTO and the patent system is a job for Congress and the oversight power of the Secretary of Commerce or the Court of Appeals for the Federal Circuit. Fixing deficiencies in the work of other government agencies is not an antitrust function so long as the decision-making in those agencies is entirely in public control.

\section{G. Walker Process: Objectively Unreasonable Infringement Actions}

Post-issuance enforcement conduct is another matter. The decision to bring an infringement suit, to threaten a suit, or to insist on a license is privately initiated. Here, antitrust can be brought to bear, but its limitations are evident. In this area the conduct is typically unilateral. This means that it must be addressed under $\S 2$ of the Sherman Act, which reaches only monopoly or attempts to monopolize. As a result, antitrust reaches only instances of improper patent infringement where monopoly is threatened.

While the Patent Act explicitly authorizes enforcement by the filing of infringement actions, ${ }^{414}$ it does not authorize improper, anticompetitive actions. In addition, access to courts and other enforcement tribunals is strongly protected under the United States Constitution, without regard to the subjective intent of the plaintiff. Objectively baseless enforcement actions are not protected. 415

In Walker Process Equip., Inc. v. Food Mach. \& Chem. Corp., the Supreme Court held that an infringement lawsuit based on a patent that had been fraudulently procured could be the basis of an antitrust violation, provided that the structural elements of an antitrust offense were present as well. 416 The lawsuit must be "baseless" under an objective test, considering whether a reasonable patentee knowing the facts would have believed the suit to be proper. ${ }^{417}$

If the conduct does not threaten monopoly, then the patent may be found invalid, but any further discipline must come through the patent court. For example, the exceptional case provision in the Patent Act, discussed below, may shift some attorney's fees for litigation misconduct, but the remedy will not go beyond that. The inadequacy of these remedies leads one to expect that the amount of deadweight loss caused by improper enforcement actions is significant, particularly where the probability of detection is low. This is the

41435 U.S.C. § 271(d)(3) (2012).

415 On the Noerr-Pennington doctrine and protection of access to the courts in antitrust

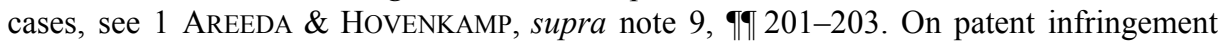
actions specifically, see 3 AREEDA \& HOVENKAMP, supra note 9, ๆ 706.

416 See Walker Process Equip., Inc. v. Food Mach. \& Chem. Corp., 382 U.S. 172, 174 80 (1965).

417 See Prof'l Real Estate Investors, Inc. v. Columbia Pictures Indus., Inc., 508 U.S. 49, 60-61 (1993). 
reason that antitrust law has a damages multiplier-designed to offset the fact that violations are difficult to detect and prove.

A good illustration of this problem is Dippin' Dots, Inc. v. Mosey, in which the patent on a popular ice cream concoction was invalid because the patent applicant had lied about barring prior sales made a decade earlier at small fairs. ${ }^{418}$ When the patentee later filed an infringement action, the sales were discovered and the lower court found both patent invalidity and an antitrust violation. The court awarded trebled attorney's fees to the infringement defendant under the antitrust attorney fee award provision. ${ }^{419}$ The Federal Circuit reversed the antitrust judgment, however, concluding that the antitrust laws required something more than mere enforcement of an improperly obtained patent. 420 It also reversed the judgment granting attorney's fees as antitrust damages. ${ }^{421}$ The result is that the only penalty that Dippin' Dots suffered was invalidation of its patent. The patent was already invalid, however. It never would have issued but for the false declaration that there had not been any disqualifying prior sales. Further, the court seems to have lost sight of the fact that clearly there was something more - the patentee had not merely obtained the patent fraudulently, but it also filed an infringement action several years later, knowing the patent to be invalid if the true facts were known.

What makes the Dippin' Dots rule particularly troublesome is that prior sales that bar patentability are "off record," known to the patent applicant but typically not to others. The patent applicant provided a sworn statement that there were no barring prior sales or uses. ${ }^{422}$ This makes the problem different than for a patent subsequently declared invalid because the applicant failed to mention known prior art ${ }^{423}$ or took inconsistent positions in front of different enforcement tribunals. ${ }^{424}$ These failures are usually on the record and discoverable later, given that many more resources are poured into patent litigation than into initial patent procurement.

The Supreme Court has partially corrected this imbalance by strengthening the Patent Act provision authorizing judges to award attorney's fees to

418 Dippin' Dots, Inc. v. Mosey, 476 F.3d 1337, 1340-41 (Fed. Cir. 2007).

419 See id. at 1342, 1349 (citing Dippin' Dots v. Mosey, No. 05-1330, slip op. at 3 (Fed. Cir. May 1, 2006)); see also 15 U.S.C. $\$ 15$ (2012) (providing for treble damages and attorney's fees to a prevailing antitrust plaintiff).

420 Dippin' Dots, 476 F.3d at 1347-48.

421 Id. at 1349.

422 See id. at 1341; see also In re Cygnus Telecomms. Tech., LLC, Patent Litig., 536 F.3d 1343, 1350 (Fed. Cir. 2008) (relying on applicant's sworn declaration). See generally 35 U.S.C. $\S 102(a)$ (2012) (detaling the novelty bar).

423 See, e.g., Nobelpharma AB v. Implant Innovations, Inc., 141 F.3d 1059, 1071 (Fed. Cir. 1998).

424 See, e.g., Therasense, Inc. v. Becton, Dickinson \& Co., 649 F.3d 1276, 1283-84 (Fed. Cir. 2011) (en banc). 
prevailing parties in "exceptional" cases. ${ }^{425}$ The Supreme Court rejected the Federal Circuit's rule that confined the use of this provision to patent infringement claims that were "frivolous" or "objectively baseless," or brought in subjective bad faith, and that required proof by "clear and convincing" evidence. ${ }^{426}$ Placing these limitations on the provision largely rendered it superfluous, the Court concluded, because the common law already permitted judges to shift fees for bad faith lawsuits. ${ }^{427}$ Shifting of attorney's fees is a fairly toothless remedy for a patent that has been improperly obtained but has been licensed out to third parties unaware of its deficiencies. Of course, all patents are probabilistic and judgments must be made about validity and scope, but they must be made with objectively measured good faith.

The time period and knowledge requirements for a Walker Process violation are not the same as those for determining pre-issuance inequitable conduct. The Walker Process doctrine considers what a reasonable patentee actually knew or should have known at the time of an infringement suit, which could be many years after patent prosecution activity. In some cases, a patent may have been obtained improperly but was subsequently assigned to an innocent purchaser with no knowledge of the improper conduct. In other cases, invalidating facts may not have been known at the time a patent was obtained but may have come to light later. Further, Walker Process is not limited to questions of invalidity resulting from inequitable conduct. It can also apply to cases that involve valid patents that are clearly not infringed or where the patentee sued without inquiring about infringement. ${ }^{428}$ The courts have even indicated that suit on an expired patent could be a Walker Process violation, although it is difficult to see how a lawsuit so easily countered could ever

42535 U.S.C. $\S 285$ (2012) ("The court in exceptional cases may award reasonable attorney fees to the prevailing party.").

${ }^{426}$ Octane Fitness, LLC v. ICON Health \& Fitness, Inc., 134 S. Ct. 1749, 1755, $1757-$ 58 (2014).

427 Id. at 1758.

428 See Synopsys, Inc. v. Magma Design Automation, 2006 WL 1452803, at*1-2 (D. Del. May 25, 2006) (holding that plaintiff adequately pled that defendant used fraudulently-obtained patents and public accusations of infringement and other disparagement to drive plaintiff out of business); Ecrix Corp. v. Exabyte Corp., 95 F. Supp. 2d 1155, 1158 (D. Colo. 2000) (permitting antitrust discovery on patentee's basis for thinking that defendant's device infringed the patent in question); United States v. Besser Mfg. Co., 96 F. Supp. 304, 312 (E.D. Mich. 1951) (dealing with machine alleged to have infringed but that patentee had never examined), aff'd, 343 U.S. 444 (1952); see also Jarrow Formulas, Inc. v. Int'l Nutrition Co., 175 F. Supp. 2d 296, 313-14 (D. Conn. 2001) (rejecting motion to dismiss on antitrust claim alleging that defendant's prior patent infringement action was objectively baseless because it did not reasonably have ownership of the patent in question). 
create durable monopoly power. ${ }^{429}$ Finally, unjustified threats to sue can also create Walker Process violations even if no lawsuit actually ensues. ${ }^{430}$

The Dippin' Dots holding is unlikely to be disciplined by circuit conflict, even though it is an antitrust holding rather than a patent law holding and the Federal Circuit has exclusive jurisdiction only over the latter. Walker Process antitrust claims are virtually always presented as counterclaims on patent infringement suits, and in most cases they are compulsory counterclaims, which means that they cannot be separately brought. ${ }^{431}$ Prior to 2012 , counterclaims to patent infringement actions were appealed to the regional circuits rather than the Federal Circuit. ${ }^{432}$ However, the Leahy-Smith America Invents Act brought counterclaims on patent infringement suits, including antitrust counterclaims, into the exclusive jurisdiction of the Federal Circuit. 433 Direct attack remains a possibility for third parties such as purchasers, however. In In re DDAVP Direct Purchaser Antitrust Litig., the Second Circuit held that it had jurisdiction over a Walker Process style lawsuit brought by purchasers who claimed that they paid more for a branded drug as a result of an improper lawsuit intended to keep generics off the market. ${ }^{434}$ Significantly, such a lawsuit does not "arise under" the Patent Act, and thus is not within the exclusive jurisdiction of the Federal Circuit.

\section{H. Refusal to License: Unilateral and Concerted}

The Patent Act provides that "no patent owner ... shall be denied relief or deemed guilty of misuse or illegal extension of the patent right by reason of his having ... refused to license or use any rights to the patent ...."435 By its terms that provision applies to unilateral and unconditional refusals to license. For example, price fixing is a refusal to license except at the cartel price, and tying is a refusal to license unless the licensee also takes the tied product. These are "conditional" refusals to license, and they are subject to the ordinary

${ }^{429}$ See, e.g., Int'1 Tech. Consultants, Inc. v. Pilkington PLC, 137 F.3d 1382, 1393 (9th Cir. 1998) (sustaining Walker Process claim involving lawsuit on expired patent).

${ }^{430}$ Goss Int'l Ams., Inc. v. MAN Roland, Inc., No. 03-cv-513-SM, 2006 WL 1575287, at *3 (D.N.H. June 2, 2006) (citing Unitherm Food Sys., Inc. v. Swift-Eckrich, Inc., 375 F.3d 1341, 1344-45, 1357-58 (Fed. Cir. 2004)) (stating that warning letters or other threats based on improperly obtained patents could satisfy Walker Process).

431 Critical-Vac Filtration Corp. v. Minuteman Int'1, Inc., 233 F.3d 697, 700-01 (2d Cir. 2000), cert. denied, 532 U.S. 1019 (2001); see also 3 AREEDA \& HovENKAMP, supra note 9 , 706e1 (noting division among the circuits on this issue).

432 See Holmes Grp., Inc. v. Vornado Air Circulation Sys., Inc., 535 U.S. 826, 831 (2002).

${ }^{433}$ Leahy-Smith America Invents Act, Pub. L. No. 112-29, 125 Stat. 284 (codified as amended in scattered sections of 28 and 35 U.S.C.).

${ }^{434}$ See In re DDAVP Direct Purchaser Antitrust Litig., 585 F.3d 677, 682, 687 (2d Cir. 2009); see also Ritz Camera \& Image, LLC v. SanDisk Corp., 700 F.3d 503, 508 (Fed. Cir. 2012).

43535 U.S.C. $\S 271(d)(4)$ (2012). 
antitrust rules. Additionally, the provision does not apply to mandatory licensing that is incorporated into a consent decree or judgment concerning some other violation, such as an unlawful merger or act of monopolization. ${ }^{436}$

The statutory provision permitting refusals to license speaks in the singular, authorizing a unilateral refusal to license. Extending it to concerted refusals to license, as the dissent in the Federal Circuit's Princo Corp. v. Int'l Trade Comm'n decision would have done, reads an unnecessarily broad immunity into the provision, disregarding competition considerations. ${ }^{437}$ In antitrust law, unilateral refusals to deal are ubiquitous and rarely unlawful. ${ }^{438}$ Reading $\S 271(\mathrm{e})$ of the Patent Act to apply to unilateral refusals simply states a policy that is consistent with United States competition policy generally.

By contrast, concerted refusals to deal, or boycotts, are fully addressable under the antitrust laws, and naked concerted refusal agreements among competitors can be unlawful per se. ${ }^{439}$ There is no obvious reason why antitrust should depart from these rules when patents are involved. Naked restraints do not further innovation, and ancillary restraints come under the rule of reason, where innovation effects can be considered if appropriate. Seen thus, the Patent Act provision on unilateral refusals does no more than add a small amount of additional limitation on an antitrust rule that is already extremely tolerant of unilateral refusals. For example, under the Aspen Skiing Co. v. Aspen Highlands Skiing Corp. decision, ${ }^{440}$ which the Supreme Court severely qualified in Verizon Communications v. Law Offices of Curtis v. Trinko, ${ }^{441} \mathrm{a}$ firm acting unilaterally has no general duty to deal with a rival. ${ }^{442}$ Nevertheless, an unjustified or unexplained withdrawal from a previous cooperative arrangement may have "evidentiary significance" entitling a jury to condemn the withdrawal. ${ }^{443}$ The Patent Act provision does not contain this limitation. Thus, for example, a dominant firm that licensed a patent to a rival for a term of, say, five years, would have no obligation to renew the license upon expiration.

Reading the Patent Act to exonerate concerted refusals from misuse or antitrust claims condones practices that should not be immunized without antitrust scrutiny. For example, a group of firms that cross-licenses a

${ }^{436}$ See 1 HovenKAMP ET AL., supra note 43, § 6.5. For a critique, see Richard A. Epstein \& F. Scott Kieff, Questioning the Frequency and Wisdom of Compulsory Licensing for Pharmaceutical Patents, 78 U. CHI. L. REV. 71, 80-83 (2011).

${ }^{437}$ See Princo Corp. v. Int'1 Trade Comm'n, 616 F.3d 1318, 1330 (Fed. Cir. 2010) (en banc); see also Bohannan \& Hovenkamp, supra note 79, at 23.

438 See, e.g., Verizon Commc'ns, Inc. v. Law Offices of Curtis V. Trinko, LLP, 540 U.S. 398, 409 (2004); Novell, Inc. v. Microsoft Corp., 731 F.3d 1064, 1080 (10th Cir. 2013).

${ }^{439}$ Rossi v. Standard Roofing, Inc., 156 F.3d 452, 464 (3d Cir. 1998).

440 Aspen Skiing Co. v. Aspen Highlands Skiing Corp., 472 U.S. 585, 600 (1985).

441 Trinko, 540 U.S. at 409.

442 Aspen Skiing Co., 472 U.S. at 600-01.

443 Id. at 601 . 
networked technology but refuses to include a firm merely because it charges a lower price or has a superior technology would be exonerated. Or two automobile companies might agree to license their patents for some technology to one another, but agree that they will not license them to a third, more competitively aggressive rival. To that extent the Federal Circuit's dicta on concerted refusals seem ill-advised and was probably made without considering the implications for competition policy.

\section{Overly Broad Remedial Demands: FRAND-Encumbered Patents}

Walker Process and lawsuits on invalid patents are not the only type of litigation exclusion. Overly broad requests for an injunction, particularly on FRAND-encumbered patents as well as lawsuits by non-practicing patent aggregators have also exposed serious potentials for patent abuse. It is unlikely, however, that these actions are antitrust violations under current law unless they arise to the level of litigation misconduct that Walker Process contemplates. In eBay Inc. v. MercExchange, the Supreme Court held that there is no automatic entitlement to an injunction for patent infringement. ${ }^{444}$ Since then, denials of an injunction to non-practicing entities have been common, although there still are a few. ${ }^{445}$

A FRAND-encumbered patent is one which the owner has promised to license on "fair, reasonable, and nondiscriminatory" terms in exchange for its designation as part of a technological standard. ${ }^{446}$ There is a growing consensus that injunctive relief should not be given to the owner of a FRAND encumbered patent, unless perhaps a firm simply continues to produce while refusing to pay anything. A recent three-judge panel of the Federal Circuit split three ways on this issue. ${ }^{447}$

Both First Amendment doctrine and our general rules about access to the courts forbid applying the antitrust laws to litigation conduct unless it is "baseless," measured by an objective test. ${ }^{448}$ In the current state of the law, a non-practicing entity that requests an injunction, or someone who asks for an injunction on a FRAND-encumbered patent, might lose. But until the courts speak more decisively these are not yet "baseless" claims, and antitrust

444 eBay Inc. v. MercExchange, LLC, 547 U.S. 388, 492-93 (2006).

445 See Ted Sichelman, Purging Patent Law of "Private Law" Remedies, 92 TEX. L. REV. 517, 540-41 (2014).

446 See Herbert Hovenkamp, Competition in Information Technologies: StandardsEssential Patents, Non-Practicing Entities, and FRAND Bidding, 2012 FORDHAM COMP. L. INST. 439, 445 (2013).

447 See generally Apple, Inc. v. Motorola, Inc., 757 F.3d 1286 (Fed. Cir. 2014). Judges Reyna and Prost and Chief Judge Rader all disagreed on entitlement to injunction on FRAND-encumbered patents. See id. at 1332; id. at 1333 (Rader, C.J., dissenting in part); $i d$. at 1342 (Prost, J., concurring in part and dissenting in part).

${ }^{448}$ Prof'l Real Estate Investors, Inc. v. Columbia Pictures Indus., Inc., 508 U.S. 49, 60 (1993). 
liability should not attach to bringing them. In any event, these questions are predominantly legal, and once an absolute rule has been adopted it is difficult to believe that asserting a lawsuit in violation of it has any prospect of creating durable monopoly power. Fundamentally, these are problems best addressed through the patent system rather than by antitrust law.

\section{J. Patent Acquisitions: Exclusive and Nonexclusive}

The Patent Act treats patents as personal property, and they are freely assignable. ${ }^{449}$ While the Patent Act expressly permits assignments, however, it does not permit anticompetitive assignments. As a result, the courts have held that patent transfers are reachable under the antitrust laws, although they have rarely found that a patent acquisition as such is anticompetitive. ${ }^{450}$ For example, one court concluded that patent acquisitions are fully reachable under the merger provision, $\S 7$ of the Clayton Act. ${ }^{451}$ It rejected an antitrust attack on Xerox's acquisition of photocopier patents that were not yet practiced at the time of the acquisition, however, because there was as yet no market subject to diminished competition..$^{452}$

The antitrust treatment of patent rights is appropriately sensitive to the type of right that is being transferred. In general, even a dominant firm can obtain a nonexclusive license without excluding anyone else, provided that the license is nonexclusive in fact as well as form. Acquisitions of nonexclusive licenses to practice may be essential to enable a firm to stay abreast of technology within its industry.

Exclusive rights are another matter. While a dominant firm needs access to technology in order to remain competitive, it does not need exclusive access. For that reason a monopolist should be limited to the acquisition of nonexclusive licenses of patents for technology in any market in which it has dominance and where market exclusion of rivals is a likely effect.

One offsetting consideration is the rights of the patentee. The value, and thus the price, of a patent reflects added value to the buyer. A patent that will create or preserve a product monopoly will claim a higher price than one that is sold into a competitive market. As a result one can expect that a monopolist intent on maintaining its market position will be willing to pay more for an exclusive right than the aggregate of potential licensees will pay to produce in a competitive market. This is borne out by the literature on pay-for-delay pharmaceutical settlements, which indicates that the value of monopoly

44935 U.S.C. $\S 261$ (2012).

${ }^{450}$ See, e.g., In re Great Lakes Chem. Corp., 103 F.T.C. 467, 473 (1984) (involving a consent order requiring nonexclusive license).

451 SCM Corp. v. Xerox Corp., 463 F. Supp. 983, 1001 (D. Conn. 1978), aff'd, 645 F.2d 1195 (2d Cir. 1981), cert denied, 455 U.S. 1016 (1982).

${ }^{452}$ See id.; see also IP ANTITRUST GUIDELINES, supra note 20, $\$ 5.7$ (concluding that patent acquisitions are reachable under $\S 7$ ). 
preservation to the pioneer patentee is worth far more than is the right of competitive entry by the generic. ${ }^{453}$

While the Patent Act gives the patentee the right to transfer, it does not create a right to make anticompetitive transfers, any more than the power to buy or sell a production plant gives the owner a right to enter into an anticompetitive transaction. For example, a production plant might claim a higher price from a monopolist purchaser than a competitor, but that does not immunize the monopoly transaction from the antitrust laws. On this point, the anti-monopolization policy of $\S 2$ of the Sherman Act and the merger policy of $\S 7$ of the Clayton Act are in accord. A patent acquisition by a monopolist or its purchase of an exclusive license could be an unlawful exclusionary practice if it denies market access to one or more rivals, even though the monopolist would be willing to pay more than an alternative buyer. ${ }^{454}$ By the same token, it can also be an unlawful merger.

Even more threatening to a competitive economy is the dominant firm's acquisition and non-use of a patent. In this case, the monopolist is seeking not only to protect its own productive technology from competition, but to shut down alternative technologies that might compete with it. In Continental Paper Bag Co. v. East Paper Bag Co., which did not raise any antitrust issues, the Supreme Court held that a dominant firm could acquire a patent in alternative technology that it was not using, and in effect put the patent "to sleep" except for the right to bring infringement lawsuits. ${ }^{455}$ Worse yet, the lawsuit had been sustained on a particularly broad reading of the patent law's doctrine of equivalents, which permits infringement actions against technologies that do not literally infringe any claim in the holder's patent. ${ }^{456}$

As a matter of patent law, Paper Bag is difficult to justify, even more today given that entitlements to an injunction are governed by ordinary equity principles. Injunctions are typically denied on unpracticed patents, although in Trebro vs. Firefly the Federal Circuit recognized an exception for a firm that competed in the market at issue but used a different technology than the one covered by the patent. ${ }^{457}$ Further, the firm had acquired the patent from someone else. ${ }^{458}$ The court held that, even though the patent in question was unpracticed, the infringement plaintiff would suffer irreparable harm, a

453 See supra note 122 and accompanying text.

454 See 3 AREEDA \& HovENKAMP, supra note 9, $9707 \mathrm{c}$.

455 See Cont'1 Paper Bag Co. v. E. Paper Bag Co., 210 U.S. 405, 427-30 (1908); see also BOHANNAN \& HOVENKAMP, supra note 3, at 295-99. The putting patents "to sleep" phrase came from CLARK, supra note 173, at 145.

${ }^{456}$ See supra note 183 and accompanying text; see also Herbert A. Johnson, The Wright Patent Wars and Early American Aviation, 69 J. AIR L. \& COM. 21, 39-40 (2004); Brian J. Love, Interring the Pioneer Invention Doctrine, 90 N.C. L. REV. 379, 392 (2012).

457 Trebro Mfg., Inc. v. Firefly Equip., LLC, 748 F.3d 1159, 1171 (Fed. Cir. 2014).

458 See id. at 1171-72; see also Erik Hovenkamp \& Thomas F. Cotter, Anticompetitive Patent Injunctions, 100 MINN. L. REV. (forthcoming 2015) (manuscript at 2-3). 
requirement for an injunction, because it and the infringement defendant were direct competitors. 459

The Trebro decision represents the worst of both worlds-doing nothing to further patent policy by actually permitting a firm to remove technology from the market altogether, while also protecting a firm from competition in precisely the circumstances it should be encouraged.

For a century or more, antitrust courts have accommodated patent policy in their decisions involving patent practices made the subject of antitrust challenge. In sharp contrast, patent law cases virtually never confront the issue except in the small subset of cases where antitrust counterclaims are raised. Does balancing of the "equities" in a patent infringement case where an injunction has been requested mean balancing a myopic set of factors having to do with injury from patent infringement, or does it require examining a broader set in which our preference for competitive markets is accorded weight as well? In Trebro, the Federal Circuit found irreparable harm because the market contained only three players and the infringement defendant FireFly was a new entrant among the three. ${ }^{460}$ The court observed that the sale of a Firefly harvester was likely to steal a sale from Trebro, and that at least one customer had switched from Trebro to Firefly. ${ }^{461}$ This theft of sales counted as "harm" to the Federal Circuit, even though Firefly's technology did not infringe the technology that Trebro was actually using in its own machines. ${ }^{462}$

But what counts as harm for purposes of patent law in this case counts as a social benefit for purposes of competition policy. The decision effectively gives dominant firms a protected right to buy up patents to technologies that they do not actually use, simply to keep them from being deployed in the market by prospective competitors. That is a great deal of harm to competition policy, for little to nothing in return from patent policy.

To be sure, the facts suggest a case for antitrust, perhaps by means of a counterclaim. In order to do that, the infringement defendant would have to show a relevant market for mechanical sod cutters, which contains only three players, and the patentee's market dominance. It would then have to show that obtaining the injunction against the new entrant under these facts constituted an exclusionary practice. That is where the rub comes in. A lawsuit on a valid patent is expressly authorized by the Patent Act and not condemned under antitrust law unless objectively unreasonable. Indeed, the Federal Circuit approved an injunction in this case. Alternatively, the infringement defendant could challenge the dominant firm's purchase of the unpracticed patent as an

${ }^{459}$ Trebro, 748 F.3d at 1171 ("[T]he fact that Trebro does not presently practice the patent does not detract from its likely irreparable harm. To the contrary, Trebro and FireFly are direct competitors selling competing products in this market. Thus, the record strongly shows a probability for irreparable harm.").

${ }^{460} \mathrm{Id}$. (noting that until recently FireFly sold only parts).

461 Id. at 1170 .

462 Id. at 1164. 
unlawful merger. If the merger were indeed unlawful, as appears likely in the Trebro case, it would not matter whether the infringement suit was reasonably brought.

A better alternative on the facts of this case is for a court of equity to intervene with a patent law rule that weighs both competition and innovation effects. Patent "misuse" doctrine once performed that function. It is not in favor today, largely because it developed during a period of rather extreme antitrust overreaching, identifying harmless patent practices as anticompetitive. ${ }^{463}$ Nevertheless, just as the "antitrust injury" doctrine, which is not articulated in any statute, forbids plaintiffs from using the antitrust laws in anticompetitive ways, ${ }^{464}$ so too patent doctrine should serve to limit uses that harm competition while doing nothing to further innovation. Before that can happen, however, courts need to think of the Patent Act as a set of legal rules that manage innovation and competition policy, not simply as a set of property rules.

\section{K. Non-Practicing Patent Aggregators Generally}

A growing body of literature indicates that the enforcement activities of patent aggregators are harming innovation. ${ }^{465}$ According to one recent report, Patent Assertion Entities (PAEs) or "trolls" file more than $60 \%$ of infringement suits. ${ }^{466}$ These are firms that acquire patents in order to monetize them. Typically, the firms are neither producers who practice their patents nor inventors who develop their patents internally.

The enforcement activities of PAEs are increasingly regarded as pure rent seeking, pursuing innovators who are sued for their own internal research, not because they have copied technology from others. For example, Mark Lemley concludes that the "overwhelming majority" of PAE-initiated infringement suits are being brought, not against copyists, but rather against those who developed an invention independently. ${ }^{467}$ In too many cases the aggregator of a large portfolio of patents brings an infringement suit against a technology company's own internally developed technology and is able to extract a significant award. In addition, often the number of defendants is large, strongly suggesting that the patent is obvious. 468

This problem exists in significant part because patent infringement is a strict liability offense, even when the patent being infringed is not being

463 See BohanNAN \& HovenKAMP, supra note 3, at 258-89.

464 See supra note 140 and accompanying text.

465 See supra note 88.

466 Exec. Office of the President, Patent Assertion and U.S. Innovation 1 (2013), available at http://www.whitehouse.gov/sites/default/files/docs/patent_report.pdf, archived at $\mathrm{http}: / /$ perma.cc/CLJ2-JVCX.

${ }^{467}$ Cotropia \& Lemley, supra note 151, at 1462; Mark A. Lemley, Should Patent Infringement Require Proof of Copying, 105 MiCH. L. REV. 1525, 1526 (2007).

468 See supra notes 199-201. 
practiced. In this respect patent law differs from copyright and trade secret law, which require actual copying as a precondition for infringement, although copying can be inferred from circumstantial evidence. The strict liability infringement rule is particularly onerous in markets for information technologies where patents are easy to obtain, numerous, costly to interpret, and difficult to search. Further, to the extent they are not explicitly practiced, there are no devices that can be examined.

These facts raise two questions, and it is important to keep them distinct. The first is whether we are issuing far too many obvious patents, with the result that people in the ordinary course of developing new ideas become unsuspecting infringers. The second has to do with the way information about patents and existing technology is disseminated. Before an innovator can proceed without concern about patent infringement the patents that already exist need to be both discovered and interpreted. To the extent that either of these activities is too costly we produce innocent infringers. As a general matter, the cost of providing notice is lower than the cost of searching - a fact that must be considered if we want to improve the system. ${ }^{469}$ Further, as long as knowledge about a patent is not required for infringement, patentees have no reason to supply any more notice than they can get away with.

The strict liability rule for patent infringement has been widely criticized, all the more because of the recent sharp increase in PAE activity. The widely used term patent "troll" suggests the catching of people who are unaware that they have committed patent infringement until they are surprised. ${ }^{470} \mathrm{~A}$ few voices defend the existing scheme, at least with qualifications, arguing that requiring proof of copying could drastically change patent law's incentive structure. ${ }^{471}$ While that argument has some force when we are talking about

469 On this point, see Herbert Hovenkamp, Notice and Patent Remedies, 88 TEX. L. REV. 221, 225 (2011); see also Tun-Jen Chiang, The Reciprocity of Search, 66 VAND. L. REV. 1, 5-6 (2013); Amanda Frye, "Inextricably Commingled": A Restitution Perspective in Patent Remedies, 26 HARV. J.L. \& TECH. 669, 687 (2013); Mark P. Gergen et al., The Supreme Court's Accidental Revolution? The Test for Permanent Injunctions, 112 CoLUM. L. REV. 203, 247 (2012); Peter S. Menell \& Michael J. Meurer, Notice Failure and Notice Externalities, 5 J. Legal ANALysis 1, 20 (2013); Stewart E. Sterk, Strict Liability and Negligence in Property Theory, 160 U. PA. L. REV. 2129, 2153 (2012).

470 See, e.g., Lemley, supra note 467, at 1525, 1526; Oskar Liivak, Rethinking the Concept of Exclusion in Patent Law, 98 GEO. L.J. 1643, 1653 (2010); Stephen M. Maurer \& Suzanne Scotchmer, The Independent Invention Defense in Intellectual Property, 69 ECONOMICA 535, 540 (2002); Carl Shapiro, Prior User Rights, 96 AM. ECON. REV. 92, 92 (2006); Samson Vermont, Independent Invention as a Defense to Patent Infringement, 105 MiCH. L. REV. 475, 479 (2006).

471 See, e.g., Clarisa Long, Information Costs in Patent and Copyright, 90 VA. L. REV. 465,528 (2004) (arguing that "an independent creation privilege in patent law would too drastically reduce incentives to create"); Merges, supra note 153, at 6 . For the practitioner viewpoint, see Roger Milgrim, An Independent Invention Defense to Patent Infringement: The Academy Talking to Itself: Should Anyone Listen?, 90 J. PAT. \& TRADEMARK OfF. SoC'Y 295, 296 (2008). 
practiced patents that are embodied in products that are widely disseminated, it seems much more strained when we are speaking of unpracticed patents that are highly complex and difficult to assess. Some compromises may be available. One would be to require proof of copying in cases where the invention is not practiced by either the infringement plaintiff or explicit licensees.

Given the high number of infringement actions filed by aggregators, this is a ballooning crisis in the patent system, particularly when one considers that such lawsuits are discouraging rather than encouraging innovative activity. To acknowledge that is to recognize a serious disconnect between what the patent system should be doing and what it is actually doing.

Using the antitrust laws in such situations presents significant difficulties, although they are not always insurmountable. First, the patent aggregator is typically not a product producer. Even if the infringement lawsuits are objectively baseless, the plaintiff is not practicing and as a result is typically not competing in the infringement defendant's product market. ${ }^{472}$ This makes the case distinguishable from Walker Process, where the improper infringement lawsuit was being used to exclude a rival. Mounting an antitrust challenge to the aggregation and enforcement of a large patent portfolio, even if the patents are unused, would require identification of a relevant market in which competition is lessened.

That is not the end of the query, however. The patent aggregator and the infringement defendant are in fact in a potential seller-buyer (licensorlicensee) relationship. Consumers as well as competitors have antitrust standing to challenge improper infringement suits that threaten higher prices in the markets in which they purchase. ${ }^{473}$

Perhaps some lawsuits by PAEs can be addressed under antitrust as well as patent law. The domain of antitrust is restricted, however, requiring proof of harm to competition as well as improper conduct. A threat of higher royalties would be sufficient, provided that the injury affects the market and not simply one firm. That is, it must at least partly be passed on to customers. To illustrate, an improper patent infringement suit forcing a few firms in a highly competitive market to pay royalties would not cause competitive harm. Such firms would not be in a position to pass their injury on to customers, so the harm would sound more in tort than antitrust. By contrast, if an improper lawsuit is brought against a firm or group of firms with a sufficient market position in their downstream product market, at least part of the royalty

472 See Erik Hovenkamp, Predatory Patent Litigation: How Patent Assertion Entities Use Reputation to Monetize Bad Patents 2 (Aug. 5, 2013) (unpublished manuscript), available at http://ssrn.com/abstract=2308115, archived at $\mathrm{http}: / /$ perma.cc/AZ49-BXW3.

473 See, e.g., Ritz Camera \& Image, LLC v. SanDisk Corp., 700 F.3d 503, 505 (Fed. Cir. 2012). 
overcharge would pass into the market itself, causing the kind of competitive injury that makes antitrust relevant. ${ }^{474}$

Even if the conduct fails to establish antitrust harm, the patent courts certainly have the power to discipline improper litigation conduct under either the exceptional case provision, which does not require competitive injury, ${ }^{475}$ or their own equitable powers.

\section{Conclusion: InNovation, Competition, AND the Equitable POWERS OF COURTS}

Antitrust and patent law are both incomplete and imperfect instruments for dealing with complex problems of the innovation economy. The American patent system is older than federal antitrust enforcement, but it has also been dominated by a property law mentality that has paid inadequate attention to the innovation and competition effects of patent law's own processes. This is in sharp contrast to antitrust law, which has been much more proactive in assimilating economic knowledge into policy.

The rise, very considerable excesses, and subsequent decline of judgemade patent "misuse" doctrine was an opportunity lost. Patent misuse doctrine promised patent law something that it needed a century ago and needs even more today-namely, a body of rules derived from patent law itself and designed to make the system more consistent with its underlying goals.

Misuse doctrine got off to a reasonably good start a century ago in the Motion Picture Patents Co. v. Universal Film Mfg. Co. case. The Supreme Court relied on patent doctrine rather than antitrust law to refuse enforcement of a clearly anticompetitive patent license restraint. ${ }^{476}$ Within a few years, however, the doctrine had gone off the rails, reaching practices such as variable proportion ties of unpatented commodities that were never shown to be offensive to either competition policy or innovation policy. 477

In an equity case, the historical remedy for a plaintiff's inequitable conduct - its "unclean hands"- is to deny relief in that case. Beginning in the 1940s, however, the Supreme Court developed a much more draconian remedy for patent misuse, making the patent unenforceable against anyone until the

${ }^{474}$ See Cascades Computer Innovation LLC v. RPX Corp., No. 12-CV-1143 YGR, 2013 WL 6247594, at *16 (N.D. Cal. Dec. 3, 2013) (refusing to dismiss antitrust complaint).

47535 U.S.C. $\$ 285$ (2012); see also supra notes 67-68 and accompanying text.

476 Motion Picture Patents Co. v. Universal Film Mfg. Co., 243 U.S. 502, 519 (1917).

477 See, e.g., Carbice Corp. of Am. v. Am. Patents Dev. Corp., 283 U.S. 27, 34 (1931); see also Mercoid Corp. v. Minneapolis-Honeywell Regulator Co., 320 U.S. 680, 684 (1944); Morton Salt Co. v. G.S. Suppiger Co., 314 U.S. 488, 491 (1942). On patent misuse, see generally BOHANNAN \& HOVENKAMP, supra note 3, at 258-89; Bohannan, supra note 310, at 497; DARYL LiM, PATENT Misuse AND ANTITRUST LAW: EMPIRICAL, DOCTRINAL AND POLICY PERSPECTIVES (2013). 
misuse was "purged." 478 Of course, that may be the effect if the inequitable conduct serves to make the patent unenforceable as a general matter, but that is hardly always the case.

Interestingly, the courts did not really need misuse to pursue what they believed to be antitrust violations such as tying. Already in 1909 the Supreme Court had recognized antitrust illegality as a defense to a breach of contract action. ${ }^{479}$ The Court held that a contract that was part of a price fixing conspiracy could not be enforced. ${ }^{480}$ There was no obvious reason that an antitrust violation could not be asserted as a defense to a patent infringement claim. Had the Supreme Court pursued that route, the law of misuse might have taken a different course.

By mid-century, Congress was rightfully unhappy with the patent misuse doctrine, and the 1952 Patent Act limited its reach. ${ }^{481}$ The limitations were expanded in 1988 to preclude tying claims unless market power in the tying product was shown, and to clarify that a unilateral refusal to license could not be misuse. ${ }^{482}$ More recently the courts have construed the doctrine so narrowly that it barely exists, ${ }^{483}$ although somewhat more room remains for a doctrine of copyright misuse. ${ }^{484}$ In general, the courts have moved from a framework that evaluates misuse claims by considering whether the conduct extends the patentee's power "beyond the scope" of the patent, to a framework that limits misuse to conduct that would otherwise violate the antitrust laws. ${ }^{485}$ The limitation makes misuse almost irrelevant. Further, it serves to take misuse out of patent policy where it belongs and place it within antitrust policy. The result has been largely to remove the federal judge's equitable powers to limit a patent remedy unless the patentee is violating the antitrust laws, breaking an explicit provision of the Patent Act, or making clear misrepresentations during patent prosecution or litigation.

478 See U.S. Gypsum v. Nat'l Gypsum Co., 352 U.S. 457, 465 (1957) (holding that plaintiff could not recover until original misuse was purged); B.B. Chem. Co. v. Ellis, 314 U.S. 495, 498 (1942) (holding patent unenforceable until misuse purged).

479 Cont'l Wall Paper Co. v. Louis Voight \& Sons Co., 212 U.S. 227, 261-62 (1909).

${ }^{480} I d$. at 262 ("The plaintiff comes into court admitting that it is an illegal combination whose operations restrain and monopolize commerce and trade among the States ... [but] a court will not lend its aid, in anyway [sic], to a party seeking to realize the fruits of an agreement that appears to be tainted with illegality . . ..”).

48135 U.S.C. $\$ 271(\mathrm{~d})(1)-(3)(2012)$.

482 Id. $\S 271(\mathrm{~d})(4)-(5)$.

483 See, e.g., Princo Corp. v. Int'l Trade Comm'n, 616 F.3d 1318, 1330 (Fed. Cir. 2010) (en banc) (refusing to extend the patent misuse doctrine to concerted refusals to license).

484 See, e.g., Assessment Techs., LLC v. WIREdata, Inc., 350 F.3d 640, 645, 647 (7th Cir. 2003) (Posner, J.) (using copyrighted software to "sequester" uncopyrighted data was a practice akin to misuse).

${ }^{485}$ See, e.g., USM Corp. v. SPS Techs., Inc., 694 F.2d 505, 510 (7th Cir. 1982) (Posner, J.) (stating that antitrust exhausts the full range of anticompetitive conduct, leaving no residual for misuse claims). 
This story is unfortunate because room remains for more patent law equity doctrine regarding conduct that falls short of an antitrust violation but is nevertheless inconsistent with patent law's purpose to facilitate innovation. ${ }^{486}$ Attempts to restrict the public domain via patent practices, to restrain innovation by others, to engage in tortious but nonmonopolistic conduct such as misrepresentation, ${ }^{487}$ or to enforce patents under circumstances that harm competition while doing nothing for innovation still need to be countered. For example, a clause in a license agreement forbidding a licensee from developing any technology in competition with the plaintiff's technology might not be a sufficient exercise of power to violate the antitrust laws, but patent law itself is concerned about practices that restrain innovation even if they are not antitrust violations. ${ }^{488}$ The same thing can be true of patent license agreements that forbid reverse engineering or that foreclose competing technologies. ${ }^{489}$ As the Supreme Court has noted, reverse engineering is an "essential part of innovation." 490

One value of misuse doctrine in such settings is that the remedy can be limited. Rather than assessing treble damages, as antitrust does, or making a patent completely unenforceable, a court could simply enjoin an abusive practice or deny relief to the plaintiff in a particular case.

"Misuse" is a doctrine of equity, ${ }^{491}$ nearly always raised as a defense to a patent infringement action. Seen in this light, the Supreme Court's eBay decision provides an important rationale for rethinking misuse. ${ }^{492}$ eBay rejected a line of Federal Circuit decisions making an injunction more-or-less automatic in patent infringement actions, largely in disregard of the Patent Act provision. ${ }^{493}$ Rather, entitlement to an injunction against patent infringement should track ordinary principles of equity, including a query whether an

${ }^{486}$ For a fuller catalog, see BOHANNAN \& HovENKAMP, supra note 3, at 258-89.

${ }^{487}$ See, e.g., Micron Tech., Inc. v. Rambus, Inc., 917 F. Supp. 2d 300, 324 (D. Del. 2013) (holding that the destruction of documents pertaining to alleged inequitable conduct in contemplation of patent litigation unlawful).

${ }^{488}$ Cf. Lasercomb Am. v. Reynolds, 911 F.2d 970, 973 (4th Cir. 1990) (finding copyright infringement in licensor's clause that "[1]icensee agrees during the term of this Agreement and for one (1) year after the termination of this Agreement, that it will not write, develop, produce or sell or assist others in the writing, developing, producing or selling computer assisted die making software, directly or indirectly without Lasercomb's prior written consent.").

489 On the latter, see U.S. Philips Corp. v. Int'1 Trade Comm'n, 424 F.3d 1179, 118990, 1193 (Fed. Cir. 2010).

490 Bonito Boats, Inc. v. Thunder Craft Boats, Inc., 489 U.S. 141, 160 (1989); see also Alcatel USA, Inc. v. DGI Tech., Inc., 166 F.3d 772, 793 (5th Cir. 1999) (holding that a restriction on reverse engineering constituted copyright misuse).

491 See B. Braun Med., Inc. v. Abbott Labs., 124 F.3d 1419, 1421 (Fed. Cir. 1997); Senza-Gel Corp. v. Seiffhart, 803 F.2d 661, 668 (Fed. Cir. 1986).

492 See eBay Inc. v. MercExchange, LLC, 547 U.S. 388 (2006).

493 See 35 U.S.C. $§ 283$ (2012) ("The several courts having jurisdiction of cases under this title may grant injunctions in accordance with the principles of equity to prevent the violation of any right secured by patent, on such terms as the court deems reasonable."). 
injunction under the circumstances is in the public interest. ${ }^{494}$ The courts have a legitimate role in policing conduct that is not expressly authorized by the Patent Act and that serves to restrain innovation, sequesters the public domain, imposes competitive harm disproportionate to innovation effects, or that involves improprieties in the patent procurement process. The Trebro decision discussed above is a good example. ${ }^{495}$ Any examination sensitive to both innovation and competition concerns should have convinced a court in equity that the public interest demanded denial of an injunction.

Calling the patentee's conduct in such cases "misuse" is probably ill advised, given the history of that term and the criticism that has properly been heaped upon its use. But eBay's equitable principles stretch far beyond "misuse" - a term that eBay's majority and two concurring opinions never used, even as every Justice agreed that the judge in a patent infringement case clearly had the power to withhold an injunction. ${ }^{496}$

Antitrust policy responded to a half century of overreaching by developing extremely strict rules for establishing competitive harm. Beginning in the 1970s and continuing to this day, antitrust has undergone a revolution in thinking that has disciplined and narrowed its focus and made its rules more consistent with its underlying goals. Patent law would benefit significantly from such a process - one that reflects consumer interests more strongly and that takes our economic knowledge of innovation and its relationship to competition and economic growth more fully into account. Today, the one enormous advantage that antitrust law has over patent law is that it confronts the economic question of impact on competition directly and explicitly, often dismissing complaints when harm to competition cannot be shown. Patent law needs to take a page from this playbook.

\footnotetext{
${ }^{494}$ See eBay, 547 U.S. at 391. In order to be entitled to an injunction the plaintiff must show:

(1) that it has suffered an irreparable injury; (2) that remedies available at law, such as monetary damages, are inadequate to compensate for that injury; (3) that, considering the balance of hardships between the plaintiff and defendant, a remedy in equity is warranted; and (4) that the public interest would not be disserved by a permanent injunction.

Id.

495 Trebro Mfg., Inc. v. Firefly Equip., LLC, 748 F.3d 1159, 1165 (Fed. Cir. 2014); see also supra notes 457-58.

496 See eBay, 547 U.S. at 394 (Thomas, J., majority opinion); id. at 394-95 (Roberts, C.J., concurring); id. at 396 (Kennedy, J., concurring).
} 